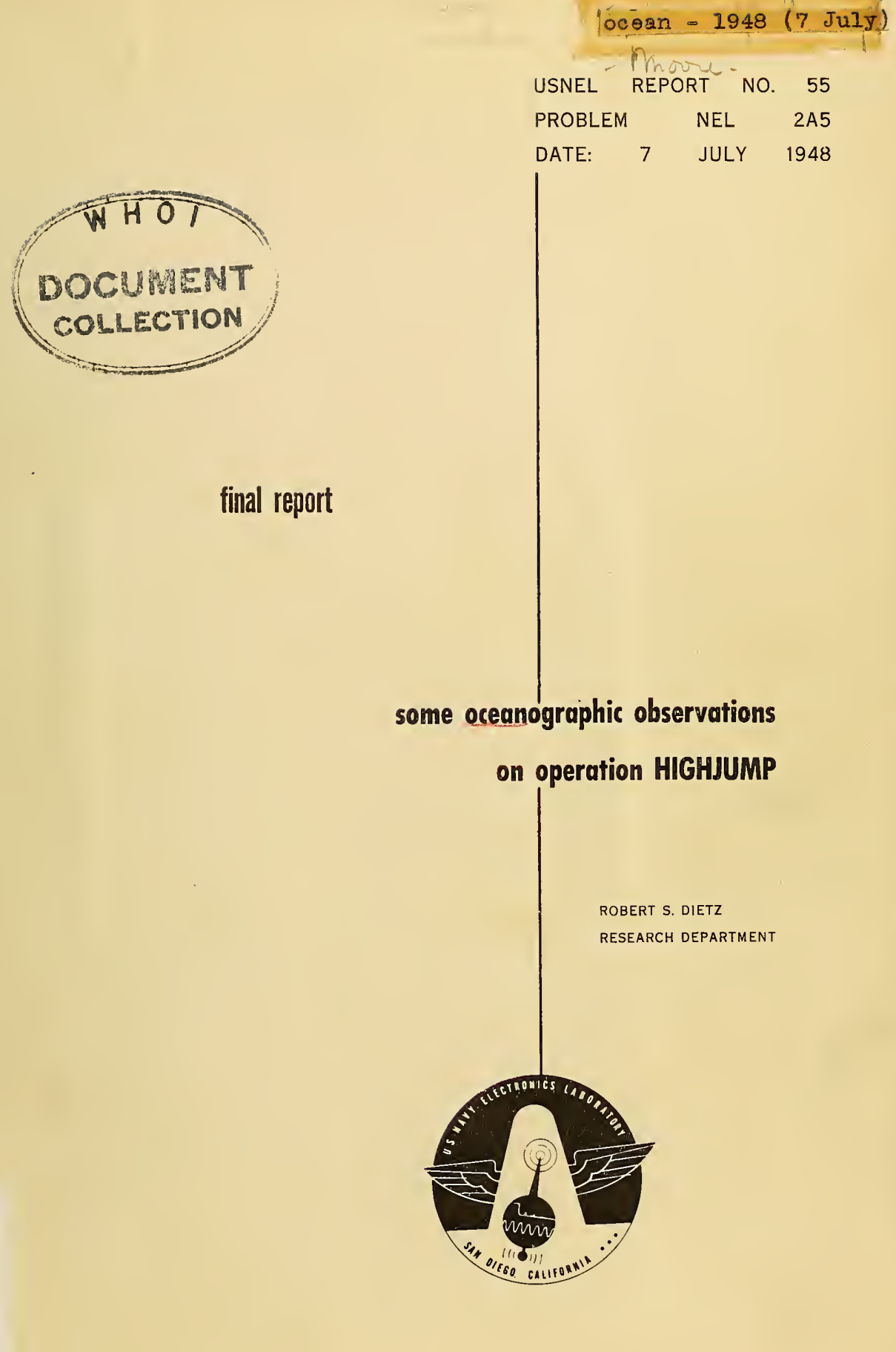




\section{acknowledgments}

The data for this report were collected by Robert S. Dietz, of the Oceanography Section of the U.S. Navy Electronics Laboratory, with the assistance of Herbert J. Mann, of the Scripps Institution of Oceanography, both of whom, as Navy Electronics Laboratory representatives, accompanied ships of the Western Task Group of Task Force 68 on Operation HIGHJUMP. Personnel of the USS HENDERSON and the USS CACOPAN furnished as istance in the collection of the oceanographic data.

The report was prepared by R. S. Dietz with assistance from and supervision by E. C. LaFond and with assistance from D. W. Pritchard. The work of Luis Capurro, who made a study of the heat content and temperature distribution in antarctic water, and the work of Estil Hamill, who investigated internal waves, are adapted for and included in this report.

The bathythermograph records were processed by the Bathythe rmograph Processing Section at the Scripps Institution of Oceanogzaphy. Salinity determinations and the analys is of a lake wate $r$ sample from Antarctica were made under the direction of N. M. Rakestraw of Scripps fnstitution of Oceanog raphy. D. M. Updegraff and Brian Boden of the same Institution furnished, respectively, bacteriological analyses of sea floor sediments and information on the antarctic phytoplankton. 


\section{abstract}

Two civilian representatives of the U.S. Navy Electronics Laboratory accompanied the Western Task Group of the U. S. Navy Antarctic Development Project of 1947 to obtain oceanographic data. Data were necessarily collected more or less at random and the areas surveyed were not always critical; even so, much useful information was obtained about regions that heretofore have been little known. This report concerns some of the results as of 31 December 1947. The geological and biological, as well as oceanographic, observations made on Operation HIGHJUMP are discussed. Much of the data are being worked up separately and will be reported elsewhere.

Oceanographic observations included temperature, salinity, and transparency measurements. The temperature data provided information concerning the thermal structure and depth of the surface layers in the antarctic, the sea surface temperatures, the Antarctic Convergence, and internal waves. The temperature and salinity data were used to determine the temperature-salinity relation in the antarctic. The geological observations included data concerning the antarctic sea floor sediments, the sea floor features, and the ice-free areas in Antarctica. The biological observations included data concerning marine growth, natural slicks, and the deep scattering layers, in the Pacific and the Antarctic Oceans. 


\section{table of contents}

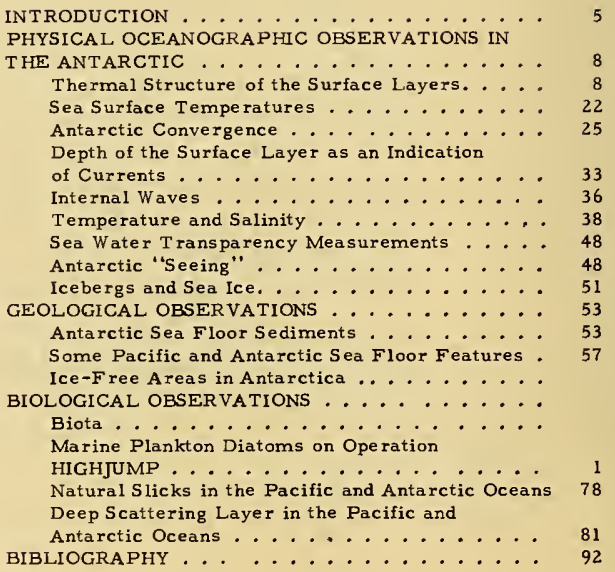




\section{list of illustrations}

1 Track chart of the USS CACOPAN and the USS HENDERSON in the antarctic on Operation HIGHJUMP ........... 6

2 Positions of the bathythermograms taken in the antarctic on Operation HIGHJUMP ..... 7

3 Positions of oceanographic samples and measurements taken from the USS HENDERSON and the USS CACOPAN on Operation HIGHJUMP ..... 7

4 Schematic representation of the development of temperature gradients in the antarctic ..... 10

5 Vertical temperature structure, type $\mathrm{W}-1 \ldots . .13$

6 Vertical temperature structure, type $S-1 \ldots . .13$

7 Vertical temperature structure, type S-1A . . . 14

8 Vertical temperature structure, type S-2 ... . 14

9 Vertical temperature structure, type $\mathrm{S}-3 \ldots \ldots .16$

10 Vertical temperature structure, type S-3..... 16

11 A verage vertical temperature structures .... 18

12 Sea surface isotherms ............. 23

13 Schematic representation of sea surface temperature section across the Antarctic Convergence ................. 26

14 Surface temperature sections across the Antarctic Convergence. . . . . . . . . 27

15 Vertical temperature sections across the Antarctic Convergence......... 30

16 Vertical temperature sections across the Antarctic Convergence. ......... 32

17 Schematic representation of mass field in the sea 34

18 Contours of layer depth as an indication of surface currents .............. 34

19 Internal waves ................ 37

20 Location of hydrographic stations. ....... 38

21 Vertical thermal structure at hydrographic stations 41

22 Vertical salinity structure at hydrographic stations 43

23 Temperature-salinity relation at hydrographic stations ...................... 45

24 Vertical distribution of $\sigma_{t}$ at hydrographic stations 45

25 Buoyancy change between 50 feet and depths to 500 feet................. 46

26 Portion of a typical "youthiul" tabular antarctic iceberg .................. 50

27 View of a typical pyramidy iceberg. . . . . . 50

28 Newly formed pads of pancake sea ice...... 52

29 Fathometer bottom trace of four Pacific seamounts 56

30 Fathograms showing a southwest Pacific sea- 56 mount, the Easter Island Swell, and the continental slope of south Australia ........ 56

31 Fathograms of two antarctic sea floor escarpments .............. 56

32 Fathogram of the continental slope of Antarctica near the Mackenzie Sea .......... 56

33 Vertical air photo showing a portion of Bungar's Oasis...................... 62

34 Oblique air photo of Bungar's Oasis .......66 65

35 Three Adelie penguins captured from an ice floe. 66

36 Seal captured from an ice floe ......... 69

37 Chart showing marine plankton diatoms identified from water samples collected during Operation HIGHJUMP .................. 70

38 Photographs of slicks in the antarctic and in

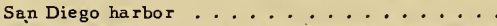

39 Map of the Pacific Ocean showing the distribution of the deep scattering layer along the tracks of the USS HENDERSON and the USS NEREUS. .

40 Fathograms showing the daytime development of the deep scattering layer. . . . . . . . .

41 Development of the deep scattering layer in the North Pacific ............ 86

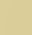

(n)

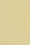

10

4

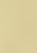




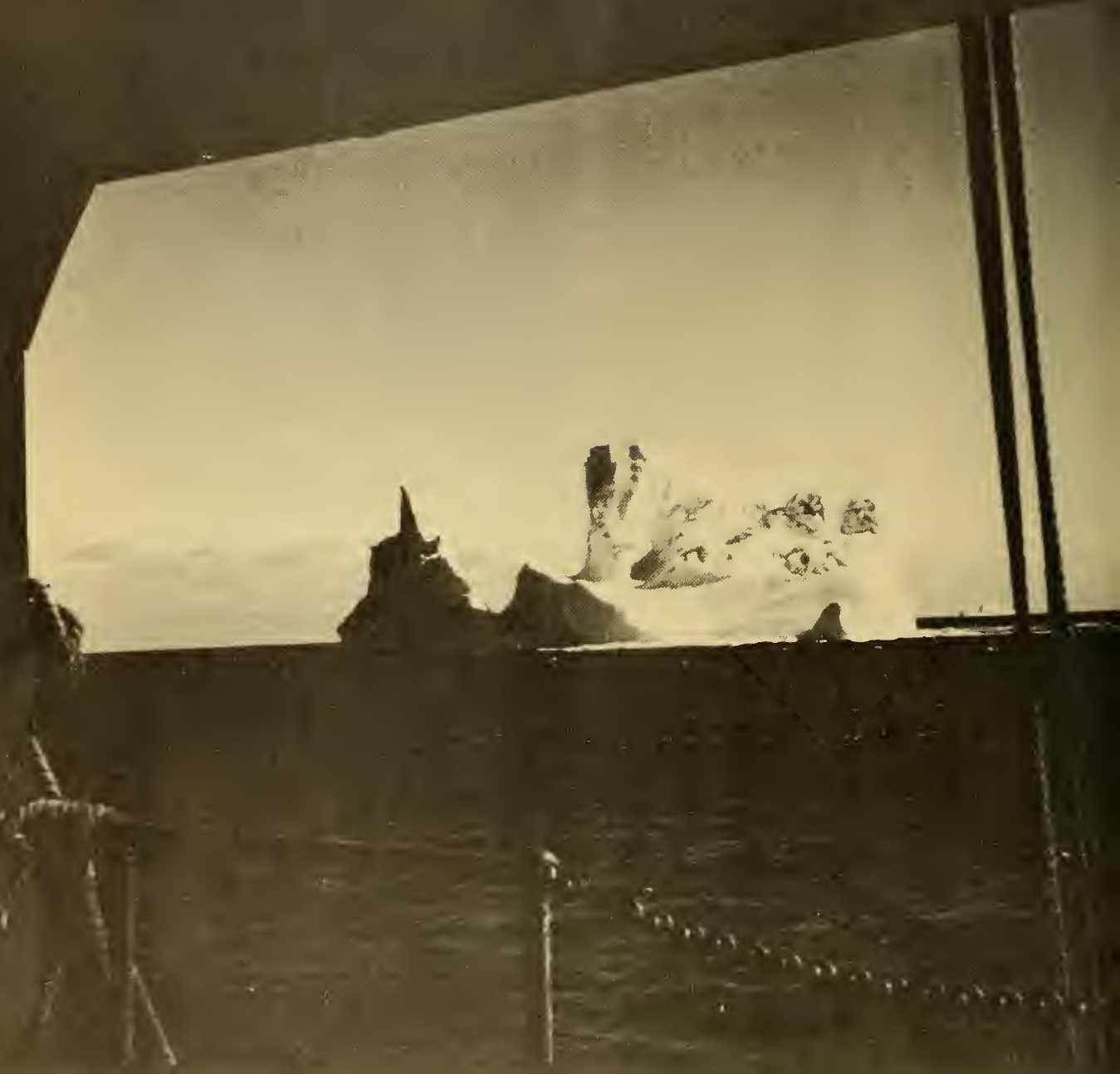




\section{introduction}

The U. S. Navy Antarctic Development Project of 1947 (Operation FIGHJUMP) was composed of three groups: the Western Task Group, the Eastern Task Group, and the Central Task Group. The Western Task Group of Task Force 68 was composed of the destroyer, the USS HENDERSON (DD785); the oiler, the USS CACOPAN (A.052); and the seaplane tender, the USS CUFiRITUCK (AV7). In order to secure oceanographic data, the author and Herbert J. Mann, civilian representatives of the U.S. Navy Electronics Laboratory, accompanied two of the ships--the USS HENDERSON and the USS CACOPAN--on Operation HIGHJUMP.

The vessels departed from the west coast of the United States on 2 December 1946 and arrived in the antarctic, in the vicinity of Balleny Island, on 23 December. The vessels then proceeded along the western Pacific and Indian Ocean sectors of Antarctica approximately as far as longitude $300 \mathrm{E}$ (see fig. 1 for a plot of the tracks of the USS HENDERSON and the USS CACOPAN in the antarctic). Backtracking to longitude $90^{\circ} \mathrm{E}$, the ships departed from the antarctic on $2 \mathrm{March}$. They reached the port of Sidney, Australia, on 14 March 1947. Departing from Australia on $20 \mathrm{March}$, they completed the return passage to the west coast of the United States early in April.

The HENDERSON and the CACOPAN had as their main objective the training of personnel under polar conditions; in addition, these two ships were expected to support the aerial photographic program of the CURRITUCK by serving as weather stations and as emergency airdromes. Oceanographic measurements were made whenever the opportunity presented itself; but, as the two ships were almost continuously underway, effort was mainly expended in making underway bathythermograph (BT) observations. These observations were made to depths of 450 feet when underway and to 900 feet when lying to (see fig. 2 for locations of BT observations in the antarctic). The HENDERSON stopped twice daily en route to the antarctic to permit oceanographic measurements to be made. Both the HENDERSON and the CACOPAN stopped periodically in the antarctic. During such periods, other data and samples were collected (see fig. 3 for locations in the antarctic of data other than BT observations). 
As there was little time to plan and to prepare for the cruise, instrumentation for special studies was not attempted. Only standard oceanographic gear such as bathythermographs, Nansen bottles, thermometers, bottom samplers, Secchi disks, and plankton nets were taken. Winches with 1200 feet of 3/32-in. wire, the type used for bathythermograph observations, were placed on the CACOPAN and HENDERSON. A spool of 5/32-in. wire, which was to be used for deep sea work, was welded to a warping winch of the CACOPAN. However, this jury rig did not prove to be very satisfactory, so most work was done with the BT winches.

Data were necessarily collected more or less at random and the areas surveyed were not always critical; even so, much useful information was obtained about regions that heretofore have been little known. This report concerns some of the results as of 31 December 1947. Much of the data are being worked up separately and will be reported elsewhere.

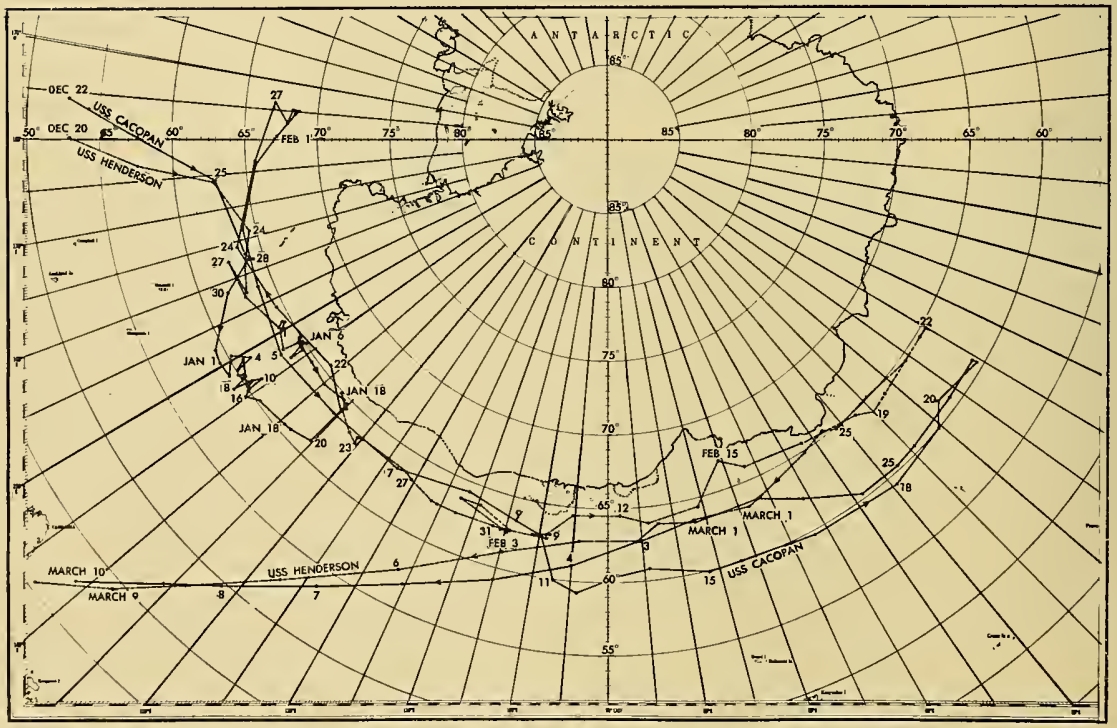

FIGURE 1. Trock chart of the USS CACOPAN and the USS HENDERSON in the antarctic on Operation HIGHJUMP. The dots mark the noon positions of the ships. 
FIGURE 2. Positions of the bothythermogroms taken in the antarctic on Operation HIGHJUMP. Solid dats ore the bathythermogroms taken by the CACOPAN and the HENDERSON. Circles are bathythermograms token by other ships of Task Force 68.

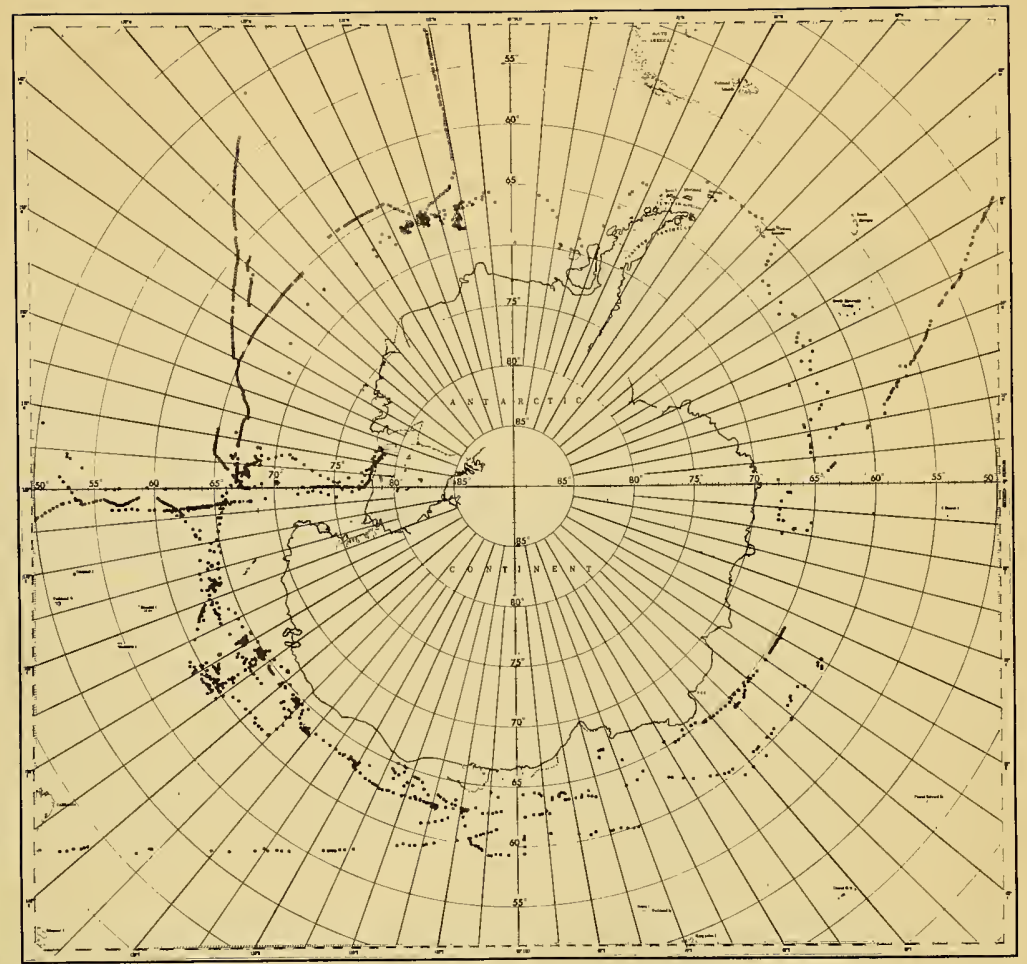

FIGURE 3. Positions of oceonographic samples and measurements (ather than bathythermograms) token from the USS HENDERSON and the USS CACOPAN on Operotion HIGHJUMP. Also shown is the position of the ice pack os determined by the HENDERSON. Water samples for quantitative study of diatoms were secured from the positions marked $H$ and $S$.

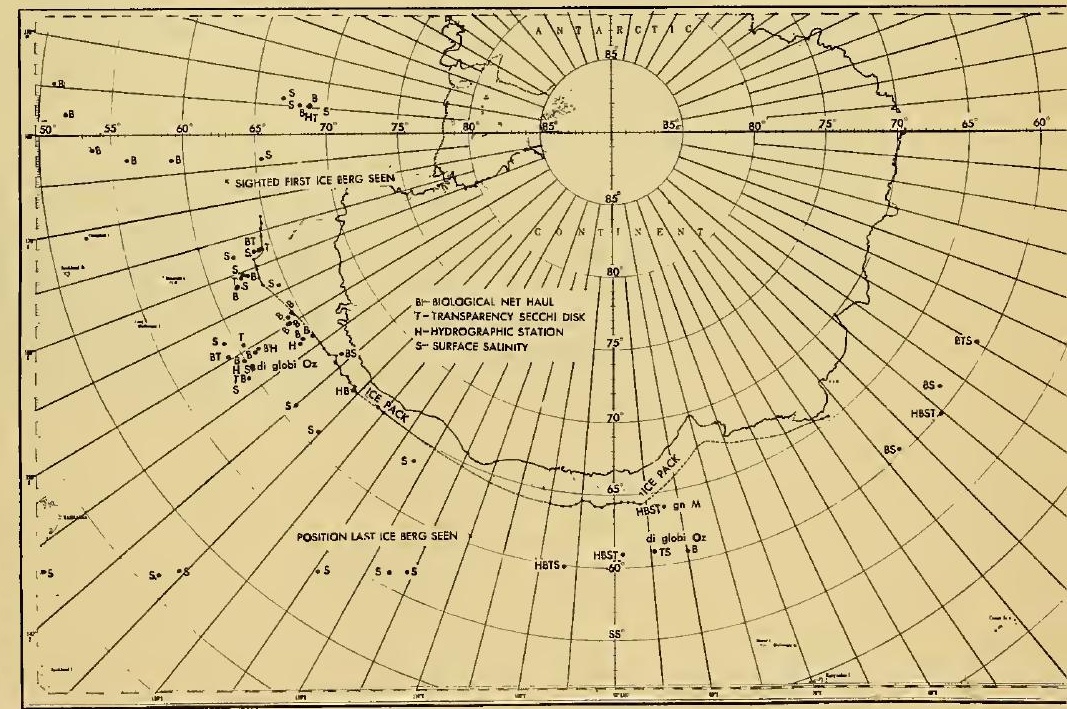




\section{physical oceanographic observations in the antarctic *}

\section{THERMAL STRUCTURE OF THE SURFACE LAYERS}

General. Scientific personnel in the Western Task Group of Operation HIGHJUMP made 1,083 bathythermograph lowerings. Lowerings were made (1) along the route of the USS CACOPAN and the USS HENDERSON from San Diego to the antarctic, (2) in the antarctic, and (3) as far as the equatorial region on the return cruise. In the antarctic region the lowerings were made periodically during the operation. They cover the area shown in figure 2, where each lowering is represented by a solid dot. The location of similar observations that were made by both the Eastern and the Central Task Groups are represented by open circles in the same figure.

The majority of the observations were made with a type CTB-40080 (450-foot maximum depth) bathythermograph; however, a large number were made with a type CTB-40180 (900-foot maximum depth) bathythermograph. In conjunction 
with the bathythermograph observations, sea surface temperatures were taken by means of buckets and injection thermometers. In addition, hourly records were made of the water temperature of the ship's sea water intake to the condenser. Although the intake for the sea water was located a few feet below the sea surface these temperatures were treated as surface temperatures because there were virtually no temperature gradients in the first few feet below the surface. No bathythermograph lowerings had been made in this region previously, but the general water characteristics had been investigated, principally by means of reversing thermometers and Nansen bottles. The bathythermograph and the sea surface temperature observations were made to try to ascertain the detailed the rmal structure of the region. A knowledge of the detailed thermal structure is useful for the efficient operation of ships and equipment as well as for numerous oceanographic studies. A few such studies from antarctic bathythermograms are discussed in this report; they include the succeeding sections: "Sea Surface Temperatures," "Antarctic Convergence," "Depth of the Surface Layer as an Indication of Currents," and "Internal Waves."

Vertical Temperature Structure. Over much of the world's ocean area the major portion of the temperature change with depth is found in a thin surface layer. The 450-foot or 900-foot bathythermographs usually reach through this layer; hence many of the major features of the temperature structure can be obtained from bathythermograph observations. 
In the antarctic region, however, relatively large temperature gradients occur at depths greater than the depth to which the bathythermograph will reach. The character of the surface traces are related to these deeper phenomena; thus the discussion of the surface layer thermal structure must neces sarily include general consideration of the character of the deeper waters.

General Character of the Thermal Structure. In the winter (June, July, and August) during a period of active cooling, the antarctic region is covered with a surface layer of nearly homogeneous water. In the southern half of the region this wate $r$ is near freezing (lower than -1 degree C.), but further north the temperature rises to +1 degree $C$. and, at the Antarctic Convergence, the northern boundary of the antarctic region, the temperature increases very abruptly.

Below this isothermal layer, which extends about 300 feet below the surface, there is a transition region in which the temperature increases with depth. This transition layer lies between the surface layer and the antarctic circumpolar water. The antarctic circumpolar water, a very large, well-defined water mass, is characterized by a temperature maximum of slightly above 2 degrees C. at a depth of between 1500 and 2000 feet. These conditions exist all around the Antarctic Continent.

In summer, during the period of increased radiation surplus, the heat is first used mainly to melt the ice. Later, some of this radiation surplus is used to heat the surface layers. The temperature increase seldom extends below

FIGURE 4. Schematic representation of the development of temper. ature gradients in the ontorctic.

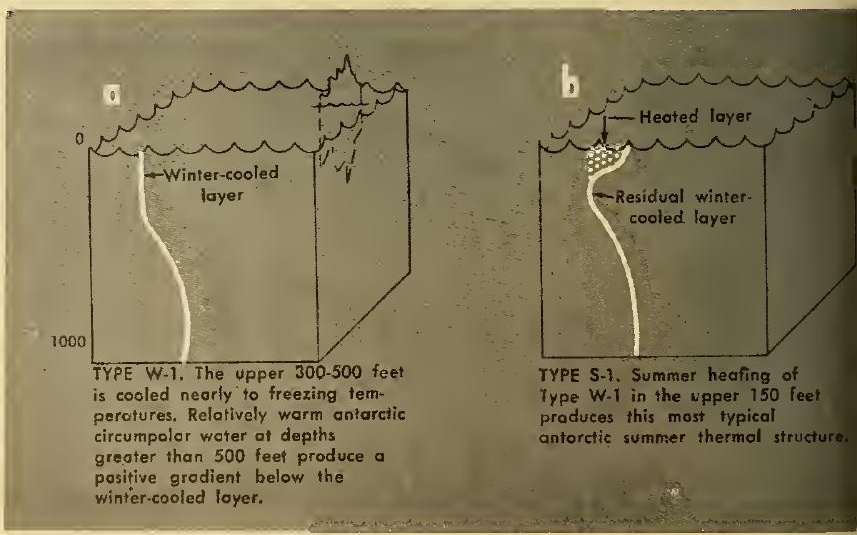


The changes in thermal structure that take place near the Antarctic Continent differ somewhat from those further north. Figure 4C represents, schematically, a block of ocean near the continent or in the Ross Sea and the corresponding winter temperature structure. The more intense cooling results in a cold isothermal layer extending to a greater depth here than in the northern region. This type of temperature structure is designated here as $\mathrm{W}-2$.

Summer heating in the higher latitudes is less pronounced; however, it extends to greater depths because of greater wind mixing (see fig. 4D). A further alteration of this summer thermal structure may result when ice. is blown either into or close to this area. This must frequently be the case as the ice pack is always present around the continent. In summer large pieces that break off the pack will drift into nearby areas which had previously been made ice-free by the radiation surplus. These melting bergs or ice floes cool the surface layer; thus a positive gradient is produced near the surface. Since this melted ice has a low salinity, the positive gradient remains fairly stable. The resulting thermal structure then consists of a warm layer between approximately 100 and 300 feet, with a positive gradient above and a negative gradient below (see fig. 4E). These last two summer types of structure are designated here as $S-2$ and $S-3$, respectively.

Typical BT Traces. Individual bathythermograph traces showing typical temperature structures obtained in the antarctic and their distribution are shown in figures 5 through 10 . These areas frequently overlap, and due to local conditions, the thermal structure typical of one particular area may occur in other areas in which a different characteristic structure predominates. Thermal structure of the type $\mathrm{W}-1$ typifies the usual antarctic surface thermal structure before surface heating has created the upper negative temperature gradient (see fig. 5). This type of structure was observed north of $70^{\circ} \mathrm{S}$ in ice-free areas only early in the summer season (December). This same structure was often found in the neighborhood of the ice floes at the entrance to the Ross Sea throughout the summer season. Type $S-1$, shown in figure 6 , represents the most typical summer thermal structure, with the summer-heated surface layer extending to about 150 feet and the residual, winter-cooled, minimum temperature layer extending to 300 and sometimes 500 feet; below this there is the transition layer with increasing temperatures with depth. 


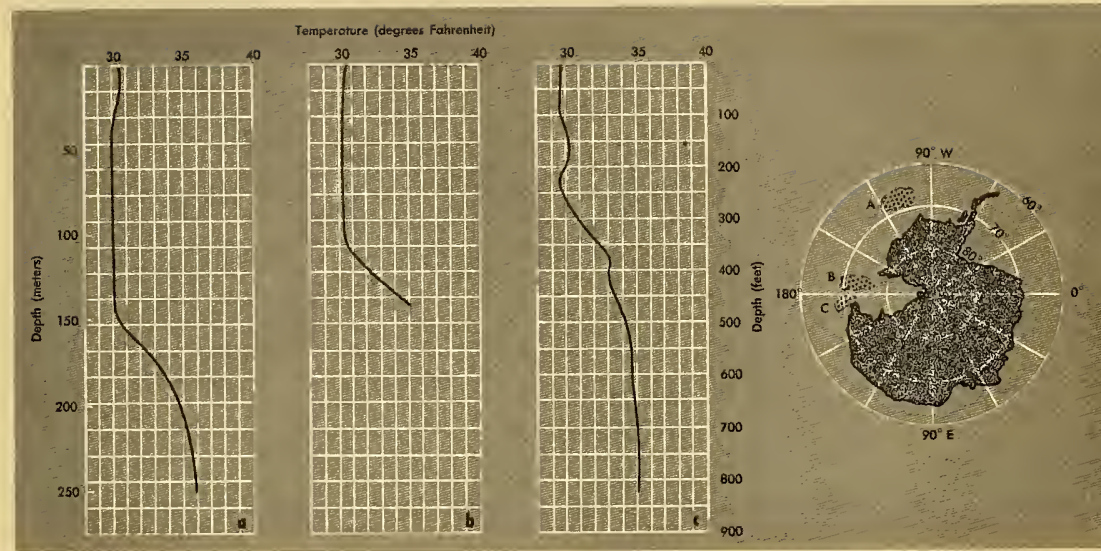

FIGURE 5. Vertical temperature structure, type W-1. During winter the surface layers are cooled to nearly freezing temperatures down to the depths of $\mathbf{2 0 0}$ to $\mathbf{5 0 0}$ feet. The traces are indicative of the thermal structure early in the summer season before surface heating has greatly altered the typical winter structure. The areas where these particular structures were observed are also indicated. Observations were not taken in other areas early enough in the season to obtain this structure.

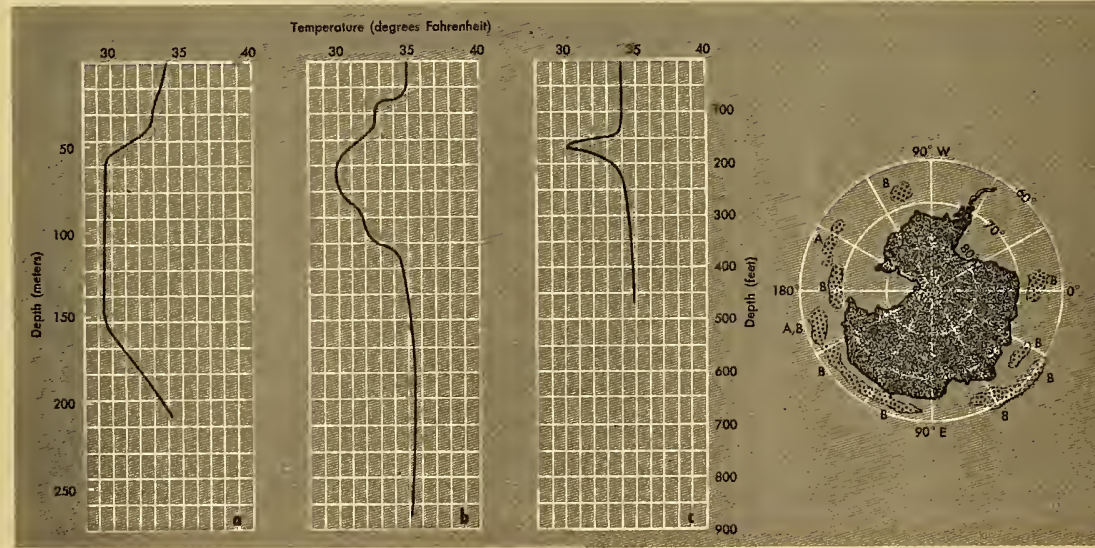

FIGURE 6. Vertical temperature structure, type S-1. The majority of bathythermograms taken in the antaretic region during the southern summer were of this general type. The typical subsurface minimum was found in a broad belt running nearly around the Antoretic Continent. The width of the belt extends from near the continent northward to between $55^{\circ}$ and $60^{\circ} \mathrm{S}$. This type was found as for south as $70^{\circ} \mathrm{S}$ in the region of the Ross Sea. 
A great many variations of a general type of structure frequently occur. For instance, type S-1A shown in figure 7 is a modification of type $S-1$, in which the subsurface temperature minimum is less well-defined. Other differences are (1) the lack of a deep isothermal layer, (2) warmer water at the surface, and (3) the general irregularities in the temperature trace. Thermal structures shown in figure $7 \mathrm{~B}$ and $7 \mathrm{C}$ are characteristic of regions of lower latitudes.

Another type of thermal structure, the $S-2$, is typical of regions in which only a slight amount of heating has taken place. Examples are shown in figure 8 . This type represents the summer transformation of type $\mathrm{W}-2$, the structure near the continent where winter cooling extends to great depths. When heating at the surface does occur it is usually distributed over considerable depth by wind mixing.

Heating of the surface layers is not necessarily continuous throughout the summer season. Near the continent and in other regions where drifting ice is moved into a previously heated region, cooling takes place in the surface layers. This results in irregular temperature structures with alternate positive and negative gradients near the surface. In some cases the positive gradients thus produced extend from the surface to a depth of several hundred feet. Most frequently, however, ice-cooled water appears as an isothermal layer over warmer water with a sharp positive gradient between the two layers. The magnitude of these increases of temperature with depth may be as much as 2 degrees $C$. Since, in the summer season, cooling is the result of melting ice, the upper cooled water will have low salinity; therefore the structure remains stable. Such structures, designated here as type $\mathrm{S}-3$, are shown in figures 9 and 10 , together with the localities where they are found. 
Change in Heat Content. The bathythermogram is ideally suited for quantitative studies of the change in heat content of the upper layers of the ocean. In order to make such a study, it is necessary to have repeated bathythermograms taken over a period of time in the same general geographical location. On Operation HIGHJUMP, the area most suited for this type of study was between latitude $65.5^{\circ} \mathrm{S}$ to $68.0^{\circ} \mathrm{S}$ and longitude $105^{\circ} \mathrm{W}$ to $112^{\circ} \mathrm{W}$. In this region observations were made during December, January, and February; consequently it is possible to study the variations in the thermal structure and hence the changes in heat content of the surface layers during this period. The distribution of bathythermograph data throughout these months in the selected area is shown in table 1 .

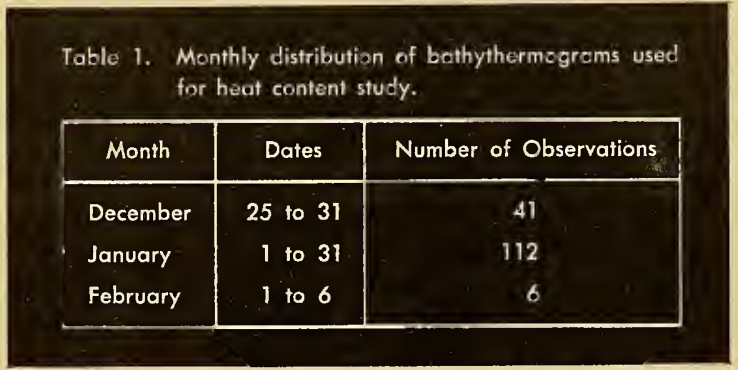

The change in the heat content in the upper layers of the sea may be considered as one term of the general heat budget of the ocean. For any given area of ocean the heat budget may be expressed by the following equation:

$$
Q_{s}-Q_{b}-Q_{i}-Q_{e}-Q_{h}+Q_{v}-Q_{\theta}=0 \text {, }
$$

where:

$Q_{s}=$ Radiation absorbed in the ocean from the sun and sky. This term represents both the radiation from the sun incident on a unit horizontal surface and the diffuse radiation from the sky, less the percentage of the two that is reflected. This term is a function of the altitude of the sun, the cloudiness, and the transparency of the atmosphere. 
$Q_{b}=$ Back radiation from the sea surface. This term represents the long-wave radiation returned to the atmosphere from the surface of the ocean and is a function of the temperature of sea surface, the cloudiness, and the humidity of the air over the ocean.

$O_{i}=$ Amount of heat used locally to melt any ice that may be present. This term may be negative and hence represent the heat given off when sea water is frozen.

$Q_{e}=$ Heat lost by evaporation from the sea surface. This term may also include the heat gained by condensation of water on the sea surface, though this effect is usually small.

$Q_{h}=$ Convection of sensible heat from the sea to the atmosphere.

$Q_{v}=$ Net amount of heat which by currents or processes of mixing is brought into the region.

$Q_{\theta}=$ Amount of heat used locally to increase the temperature of the sea water.

The bathythermograms provide the necessary data for the computation of the term $Q_{\theta}$. Since this term represents the heat used in changing the temperature of the water, it is necessary to determine the change in the relative heat content of the surface layers. The evaluation of this term $Q_{\theta}$ involves the averaging of the temperatures from bathythermograms for each month for depths down to 450 feet. The resulting average temperature-depth curve for each month is shown in figure 11 .

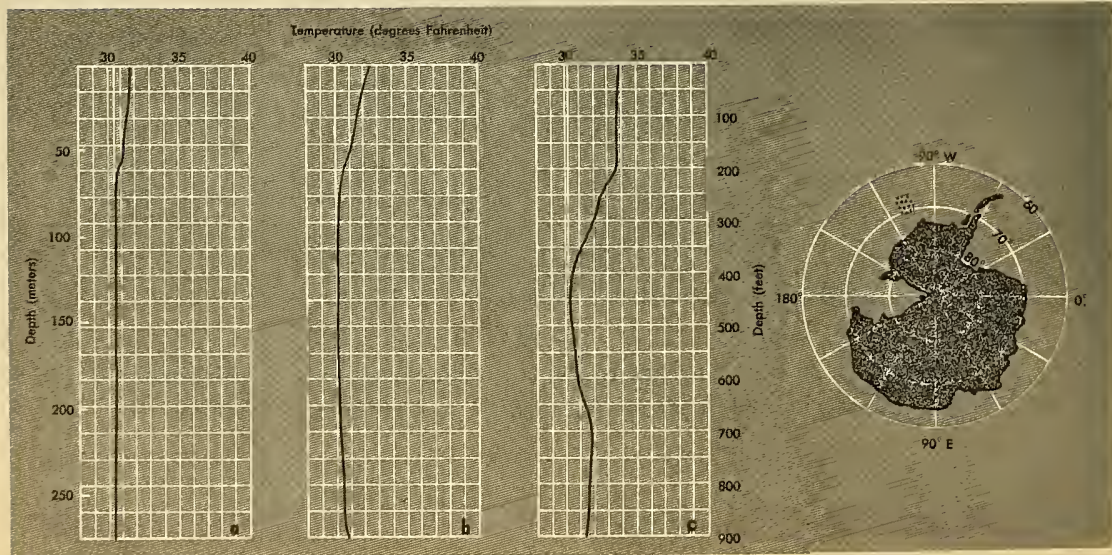

FIGURE 11. Average vertical temperature structure abserved during December (A), January (B), and February (C), between $66.5^{\circ}$ and $68.0^{\circ} \mathrm{S}$ and $105.0^{\circ}$ and $112.0^{\circ} \mathrm{W}$ (see plat af area). 
The average monthly curves, since they are combinations of a large number of bathythermograms taken at different times and at slightly different geographical positions, will be somewhat smoothed. This results in the minimizing of certain characteristic features such as the sharpness of the thermocline. However, these curves give a reasonable representation of the relative heat content in the surface layers.

Qualitative investigations lead to the conclusion that within the antarctic region the heating of the surface layers does not extend below 200 feet. Changes in the thermal structure below this depth must be related to advection. In view of this fact the relative heat contents of each of the average thermal structures have been computed only for the upper 200 feet, using the temperature at 200 feet as the reference temperature. The computation of the relative heat content involved the numerical integration of the equation:

$$
H_{200}=a \bar{p} c_{p}{ }^{200} \Delta t_{d} d z,
$$

$a=$ conversion factor involving conversion of feet to $\mathrm{cm}$. and of ${ }^{\circ} \mathrm{F}$ to ${ }^{\circ} \mathrm{C}$.

$$
\begin{aligned}
& \qquad \bar{\rho}=\text { average density of the column of sea water. } \\
& c_{F}=\text { specific heat of sea water. } \\
& \Delta t_{d}=t_{r}-t_{200} \text {; i.e., the temperature at the depth, d, minus } \\
& \text { the temperature at } 200 \text { feet. }
\end{aligned}
$$

$$
z=\text { the vertical variable, positive downwards. }
$$

The resulting relative heat content for each of the three months is shown in table 2 .

\section{Tokle 2. Relintive heat content.}

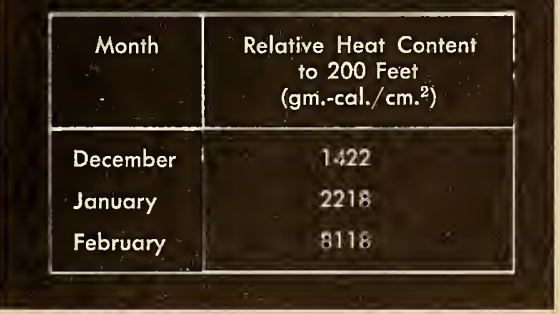


The difference between these quantities represents the amount of heat that has gone into increasing the temperature. Since the terms in the heat budget are usually expressed in gram-calories per square centimeter per minute, $Q_{\theta}$ may be found by dividing the differences between two values of heat content by the number of minutes between the middle of each of the two periods over which the heat content was determined. The amount of heat which has been used to increase the temperature in the interval from 25 to 31 December and 1 to 31 January and in the interval between this latter period and 1 to $6 \mathrm{February}$, are presented in table 3, together with the corresponding values of $Q_{\theta}$. The central day in each period is used to represent the period.

\section{Table 3. Heat used to raise the temperature in the surface loyers.}

\begin{tabular}{|c|c|c|}
\hline Time Interval & $\begin{array}{l}\text { Change in Heat Content } \\
\left(\mathrm{gm} . \text {-cal. } / \mathrm{cm}^{2}\right)\end{array}$ & $\underset{\left(\text { gm.-cal. } / \text { cm. }{ }^{2} / \mathrm{min} \text {.) }\right.}{\mathbf{Q}_{\theta}}$ \\
\hline $\begin{array}{l}\text { December } 26 \\
\text { to January } 16\end{array}$ & 796 & 0.028 \\
\hline $\begin{array}{l}\text { Januery } 16 \\
\text { to Februery } 3\end{array}$ & 5900 & 0.165 \\
\hline
\end{tabular}

The equation for the heat budget may be simplified somewhat since considerations of the processes which maintain evaporation and heat conduction lead to the development of an expression for the ratio of the convection of sensible heat to the heat lost by evaporation. This ratio, $R=Q_{h} / Q_{e}$, is called the Bowen ratio and may be determined from the observations of the moisture and temperature gradients over the sea. In this case the equation becomes:

$$
Q_{s}-Q_{b}-Q_{i}-Q_{e}(1+R)-Q_{v}-Q_{\theta}=0 .
$$


During the period from 28 December to 16 January the term $Q_{s}-Q_{b}$ is of the order of magnitude of $0.2 \mathrm{gm}$.-cal. $/ \mathrm{cm}^{2}$ per minute. During this same period the Bowen ratio was calculated to have a value close to minus one.* This means that the heat lost by evaporation is nearly balanced by the heat gained through conduction and hence the term $Q_{e}(1+R)$ is very small. It is thus seen that the term $Q_{v}-Q_{i}$ must account for the excess of incoming radiation, since, as seen from table $3, Q_{\theta}$ is equal to $0.028 \mathrm{gm} .-\mathrm{cal} . / \mathrm{cm} .{ }^{2}$ per minute and hence is only about $1 / 7$ as large as the term $Q_{s}-Q_{b}$.

The term $Q_{V}$ is very difficult to estimate and in most cases in the ocean even impossible. It is generally considered small; however, in the Antarctic Ocean, this assumption may not be valid since the shifting of the Antarctic Convergence, as described elsewhere in this report, may displace the surface waters by water of very different character. However, since the melting of ice is known to be important during the December-January period, it may be assumed that a considerable portion of the excess radiation goes into melting the ice.

During the period from 16 January to $3 \mathrm{February}$, the heat balance is much more difficult to explain. During this period the incoming radiation decreases somewhat and the terms $Q_{s}-Q_{b}$, and $Q_{\theta}\left(0.195 \mathrm{gm} .-\mathrm{cal} . / \mathrm{cm} .^{2}\right.$ per minute) are of the same order of magnitude. Investigation of the Bowen ratio indicates that during this period more heat was lost by evaporation than was gained by conduction; in fact, during the last part of the interval, the conduction term also led to a loss of heat from the surface layers. Since the term $Q_{i}$ may be neglected during this period, it appears that the advection term, $Q_{v}$, must have brought sufficient heat into the area to balance the heat budget.

These considerations may be applied to a discussion of the seasonal change in the thermal structure as indicated by the average curves shown in figure 11. During winter the entire area must be covered by a layer of cold isothermal water. The average curve for late December shows only a 
slight negative gradient in the upper $100 \mathrm{feet}$, below which nearly isothermal conditions are found to nearly 450 feet. Thus only a small amount of heat has been used to raise the temperature of the surface layers. During January the surface temperature has increased and consequently the negative gradient is stronger. Heating does not extend below 125 feet; however it is sufficiently strong to resist the formation of an isothermal layer.

Between mid-January and early February, considerable change has taken place. By February the surface has been warmed nearly 1 degree $C$. and the processes leading to mixing (wind stirring and evaporation) have resulted in a nearly is othermal layer to 200 feet. Below this a negative gradient extends to the cold, winter-cooled layer at 400 feet.

The changes in the thermal structure below 200 feet may be related to rising of the antarctic circumpolar water neare $r$ the surface, thus bringing the transition laye $r$ of positive gradient between 400 and $700 \mathrm{feet}$, as shown in the average curve for February.

SEA SURFACE TEMPERATURES

General. Sea surface temperature observations were available in sufficient number to construct isotherms completely around the Antarctic Continent. However, it was necessary to make interpolations in some regions. Surface temperature data analyzed in this report comprise observations made by all three task groups on Operation HIGHJUMP. Although a few of the temperatures were obtained as far south as $78^{\circ} 52^{\prime} \mathrm{S}$, by far the greater number of the observations were taken between $60^{\circ} \mathrm{S}$ and $70^{\circ} \mathrm{S}$. Observations extended over the period from December to March. The majority of the observations, however, were made during the months of January and February (see table 4).

Table 4. Monthly distribution of sea surface temperature observations.

\begin{tabular}{|ll|c|c|}
\hline \multicolumn{2}{|c|}{ Month } & Number of Observations & Per Cent of Total \\
\hline December & 1946 & 434 & 23 \\
Jenuury & 1947 & 815 & 43 \\
February & 1947 & 498 & 27 \\
March & 1947 & 128 & 7 \\
\hline
\end{tabular}


Analysis of Data. The available sea surface temperatures were, for the most part, averaged for each 1-degree quadrangle of latitude and longitude. In the areas where the horizontal temperature gradients were small, the sea surface temperatures were averaged for 5-degree quadrangles. The main objectives were to determine the geographical distribution of surface temperature and to locate the Antarctic Convergence. Therefore, in areas where the gradients were large, the sea surface temperatures were not averaged, as the averaging process might have eliminated the large gradients indicative of the convergence. The average values were then plotted on a chart showing the bottom configuration so the influence of the topography on the distribution of the is otherms could be studied.

Whole-degree isotherms were drawn, using the abovedescribed temperature plots. Sufficient data were available to construct isotherms from only -1 degree C. to 3 degrees C. (see fig. 12). In areas where data were lacking from Operation HIGHJUMP (see fig. 2), the location of the isotherms was determined by using data from the Discovery Reports ${ }^{1}$ and then considering the probable effect of the bottom topography on the pattern of the isotherms.

FIGURE 12. Sea surface isotherms.

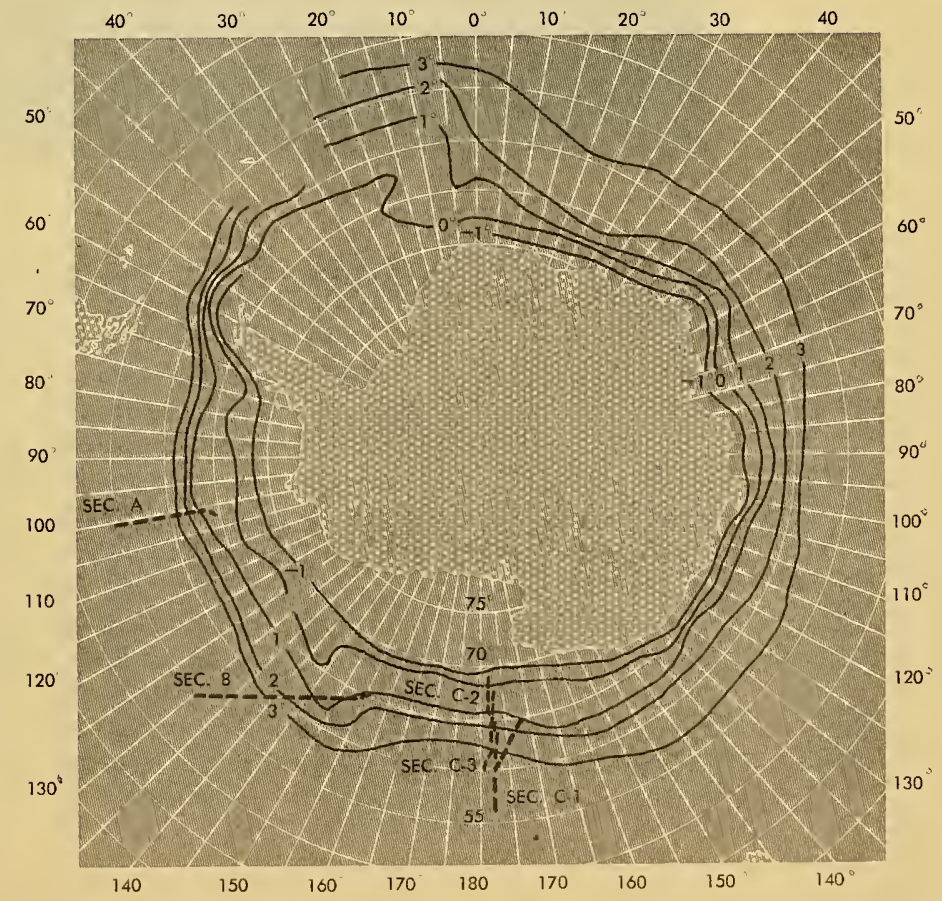


The general trend of the sea surface is otherms obtained from Operation HIGHJUMP data is similar to the trend of those previously obtained from the Discovery Expedition. However, the HIGHJUMP data indicate an over-all southward displacement of the isotherms. This southward displacement is shown in table 5 where the position of the zero-degree C. is otherm on Operation HIGHJUMP $(1946-47)$ is compared to its position as shown in the Discovery Reports.

Toble 5. Comparison of position of the zero-degree Contigrade iso-
therm as observed on the Discovery end HIGHJUMP cruises.
\begin{tabular}{|c|c|c|c|}
\hline Longitude & $\begin{array}{c}\text { Latitude } \\
\text { (Discovery) }\end{array}$ & $\begin{array}{c}\text { Latitude } \\
\text { (HIGHJUMP) }\end{array}$ & $\begin{array}{c}\text { Difference } \\
\text { (miles) }\end{array}$ \\
\hline $180^{\circ} \mathrm{E}$ & $62^{\circ} \mathrm{S}$ & $67^{\circ} \mathrm{S}$ & 300 \\
$135^{\circ}$ & $62^{\circ}$ & $64^{\circ}$ & 120 \\
$90^{\circ}$ & $59^{\circ}$ & $62^{\circ}$ & 180 \\
$45^{\circ}$ & $61^{\circ}$ & $66^{\circ}$ & 300 \\
$0^{\circ}$ & $60^{\circ}$ & $60^{\circ}$ & 0 \\
$45^{\circ} \mathrm{W}$ & $60^{\circ}$ & $62^{\circ}$ & 120 \\
$90^{\circ}$ & 63 & $66^{\circ}$ & 180 \\
$135^{\circ}$ & $59^{\circ}$ & $66^{\circ}$ & 420 \\
\hline
\end{tabular}

The remaining isotherms ( -1 to 3 degrees C.) are displaced much the same as the zero-degree C. isotherm in both direction and amount. As can be seen from the table there is a large variation in the location of the zero-degree C. isotherm except at the zero-degree meridian.

This general southern displacement of is otherms might be explained if, in the year of the HIGHJUMP observations, there was an unusually strong the rmohaline circulation toward the south, associated with a weak wind circulation in the antarctic region which did not offset the south-flowing thermohaline current. Thermohaline circulations are related to the heating in low latitudes and cooling in high latitudes. Thus the greater abundance of ice encountered on HIGHJUMP than in previous years indicated excessive cooling in the region and suggests a stronger thermohaline circulation. 
As stated previously, the sea surface temperature chart (see fig. 12) is based on observations made during four different months. In some regions, observations were repeated so that the seasonal change could be investigated. A summary of the month-to-month changes observed are shown in table 6 .

Table 6. Average sea surface temperature changes.

\begin{tabular}{|l|c|c|}
\hline \multicolumn{1}{|c|}{ Time Interval } & $\begin{array}{r}\text { Temperature Change } \\
\text { (degrees C.) }\end{array}$ & Number of Observations \\
\hline December to Jonuary & 0.5 & 19 \\
January to February & -0.3 & 14 \\
February to Morch & -0.3 & 5 \\
December to February & 0.8 & 10 \\
\hline
\end{tabular}

\section{ANTARCTIC CONVERGENCE}

General. Proceeding southward from the region of warm surface water in the low latitudes, one first encounters gradual decreasing temperatures. However, in a region between $55^{\circ} \mathrm{S}$ and $65^{\circ} \mathrm{S}$, the temperature decreases markedly within a short distance. Beyond this region of strong horizontal temperature gradients, the surface temperatures remain rather constant and near the freezing point. This boundary is a region where part of the cold antarctic surface water, brought northward by the transverse circulation created by the westerly wind system, sinks below the warmer water transported southward by the thermohaline circulation which dominates in the subantarctic region. This area of sinking is called the Antarctic Convergence.

As indicated in the section, "Icebergs and Sea Ice," the convergence was quite apparent as an abrupt water-mass 
boundary. Soon after crossing it, observers on the HENDER$S O N$ encountered their first group of icebergs. As the convergence was crossed, the water changed in color from blue to gray, new types of birds appeared, and the sky cleared. These changes closely followed the drop in temperature which was over 2.5 degrees $C$. in about 20 miles.

Location of the Convergence. As an aid in locating the Antarctic Convergence, as well as presenting the complexities of the antarctic thermal structure, horizontal temperature plots and vertical cross sections of temperature versus depth have been constructed for five locations as shown on the chart in figure 12. They are numbered $A, B, C-1, C-2$, and $\mathrm{C}-3$ for reference.

Both the plots and cross sections are based on a series of bathythermograph observations taken by individual ships on nearly straight runs across the convergence. Three of the sections, C-1, C-2, and C-3 were taken in the same locality and serve to indicate the seasonal trends in the location of the convergence. These features are discussed more fully below.

Horizontal Surface Temperature Sections. Ideally, if the surface temperatures were plotted against latitude, with temperature as the vertical coordinate and latitude as the horizontal coordinate, the Antarctic Convergence should appear on such a plot as a sharp break in the slope of the surface temperature curve. A schematic presentation of such a graph under ideal conditions is shown in figure 13.

FIGURE 13. Schematic representation of sea surfoce temperature section across

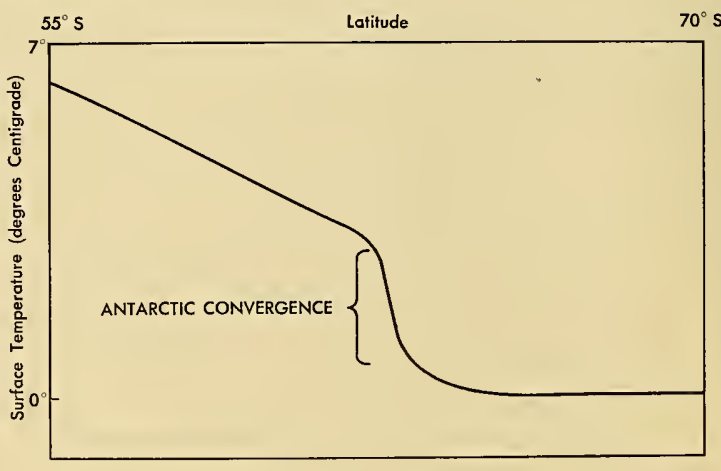
the Antarctic Convergence. 
When actual observed values of surface temperatures are plotted in the above fashion, erratic variations of the surface temperature complicate the picture considerably (see fig. 14). The more observations available, the more complex the surface temperature fluctuations appear. They are related to the variations in the meteorological conditions, currents, and melting ice, as well as to the convergence circulation. However, in each section the characteristic break in temperature is easily discernible.

Cross section $\mathrm{A}$ was taken during late December along a north-south line which closely followed the $100^{\circ} \mathrm{W}$ meridian. The sharp break in slope of the surface temperature plot is apparent at about $61^{\circ} 47^{\prime} \mathrm{S}$ with a mean temperature of 3.2 degrees C. on the steepest part of the slope (see table 7). This is a higher temperature than was observed at the convergence on any of the other sections. The surface temperature decreases about 2.2 degrees $C$. in a distance of 20 miles.

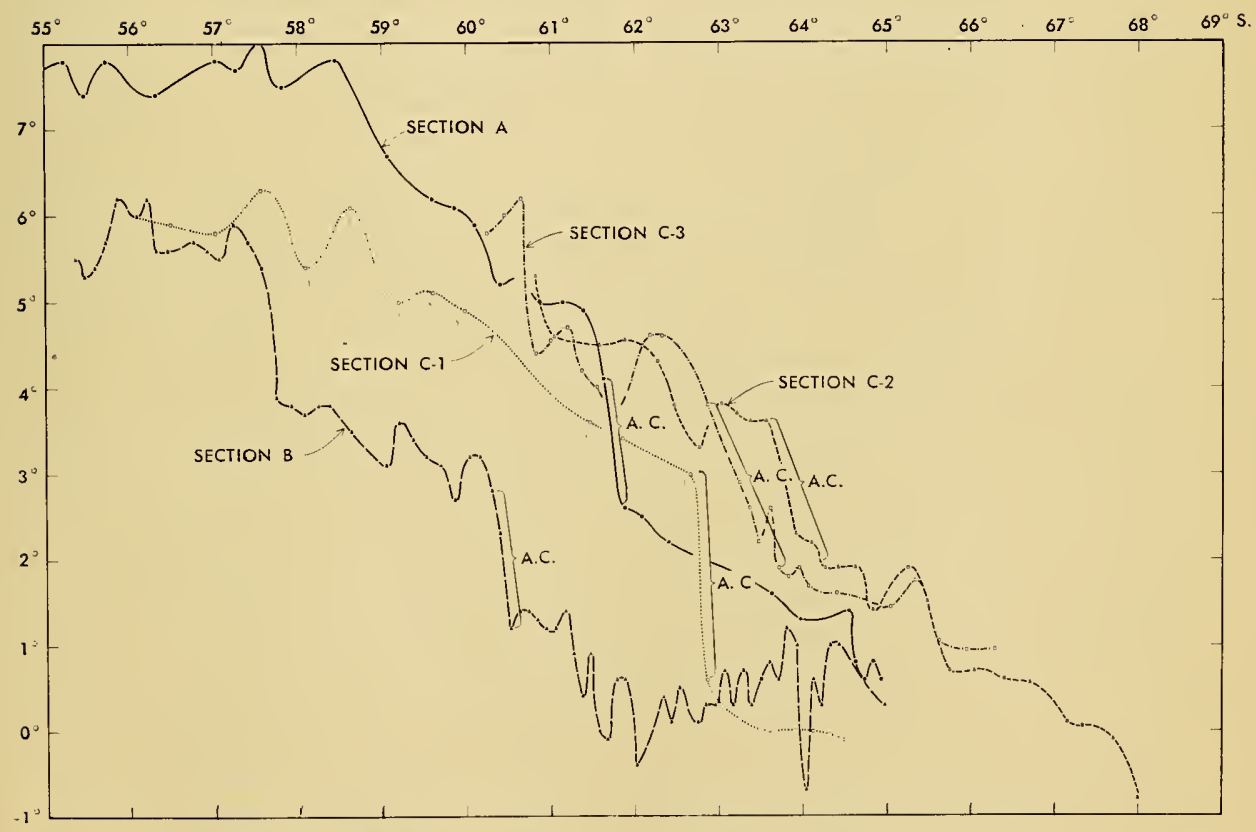

FIGURE 14. Surface temperature sections acrass the Antarctic Convergence. 
Table 7. Location of temperature sections across the Antarctic Convergence.

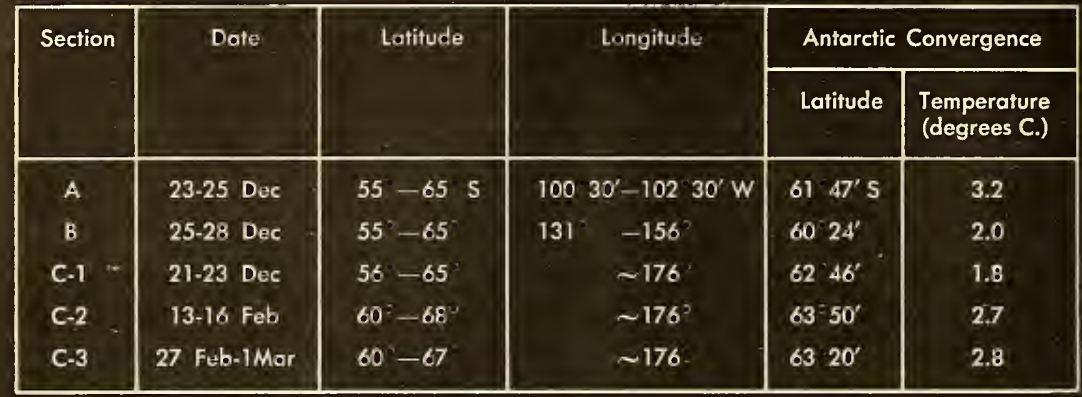

In section $B$, which lies 40 degrees to the west of section $A$, the large temperature gradient indicative of the convergence was found much farther north at $60^{\circ} 24^{\prime} \mathrm{S}$. The observations are more closely spaced in this section and consequently give a more variable temperature structure. The temperature gradient at the convergence on this section is about 2.0 degrees $C$, in 15 miles.

Sections $C-1, C-2$, and $C-3$, which are all in one locality, give indications of seasonal changes in the surface temperatures at the convergence. In section $\mathrm{C}-1$ the convergence was found early in the season at $62^{\circ} 46^{\prime} \mathrm{S}$ with a mean temperature of about 1.8 degrees $C$. This is the most striking break in temperature found. The decrease is 2.5 degrees $C$. in a distance of 10 miles. Section $\mathrm{C}-2$ taken 54 days later shows the convergence at $63^{\circ} 50^{\prime} \mathrm{S}$ with a mean temperature of $2.7 \mathrm{de}-$ grees $C$. This indicates that the convergence had moved south about 64 miles and the temperature at the convergence increased by 0.9 degree $C$. The temperature gradient decreased to 1.8 degrees $C$. in 30 miles. The third section in the same longitude shows that the convergence again moved north to about $63^{\circ} 20^{\prime} \mathrm{S}$ with a mean temperature of 2.8 degrees C. This northerly displacement amounts to 30 miles in a period of 14 days. The surface temperature gradient here is 2.8 degrees $C$. in approximately 80 miles. A summary of the surface temperature characteristics at the convergence is contained in table 7 . 
Vertical Temperature Section. The convergence should be marked at subsurface depths by a continuation of the sharp gradients found at the surface. Another important indication of the northern limit of the antarctic region, hence of the location of the Antarctic Convergence, is the position of the northern boundary of the subsurface temperature minimum which develops in summer. The development of this typical summer thermal structure in the antarctic region was discussed earlier. North of the Antarctic Convergence the temperature continuously decreases with depth, and the typical minimum at 200 to 500 feet is not developed. This subsurface temperature structure characteristic of the Antarctic Convergence is demonstrated by vertical cross section plots of the five crossings (see figs. 15 and 16). On these cross sections all areas below zero degrees $C$. have been shaded in order to indicate the location of the subsurface minimum.

In vertical section, figure $15 \mathrm{~A}$, the temperature gradient between 2 and 3.5 degrees $C$. continues to mark the convergence as it slopes downward to the north below the warmer subantarctic surface water. Taking the 3-degree C. isotherm as indicative of the location of the boundary between the two water masses at the convergence zone, it is seen that this boundary has a slope downward toward the north of $3 \times 10^{-3}$ in the upper 400 feet; that is the cold antarctic intermediate water sinks below the warmer subantarctic surface water at the rate of eighteen feet for each mile to the north. South of the Antarctic Convergence the typical area of subsurface minimum temperature does not appear well-developed.

The vertical temperature cross section shown in figure $15 \mathrm{~B}$ is particularly interesting since bathythermographs were taken at very short intervals in the southward progress of the USS NORTHWIND. The detail shown here points out that the usual cross section drawn from stations spread in much larger intervals presents a very smoothed picture of the vertical thermal structure. The apparent thermal structure is very complicated indeed, appearing more and more complicated the greater the detail of the observations. Internal waves, which are discussed later, may contribute greatly to the complicated thermal structure shown here.

The boundary zone in this vertical temperature section (fig. 15B) is fairly well marked at subsurface depths between the 1 -degree $C$. and the 3 -degree $C$. isotherms. This zone has an average slope of about $4 \times 10^{-4}$ in the upper 300 feet. The region of subsurface temperature minimum, shown by 

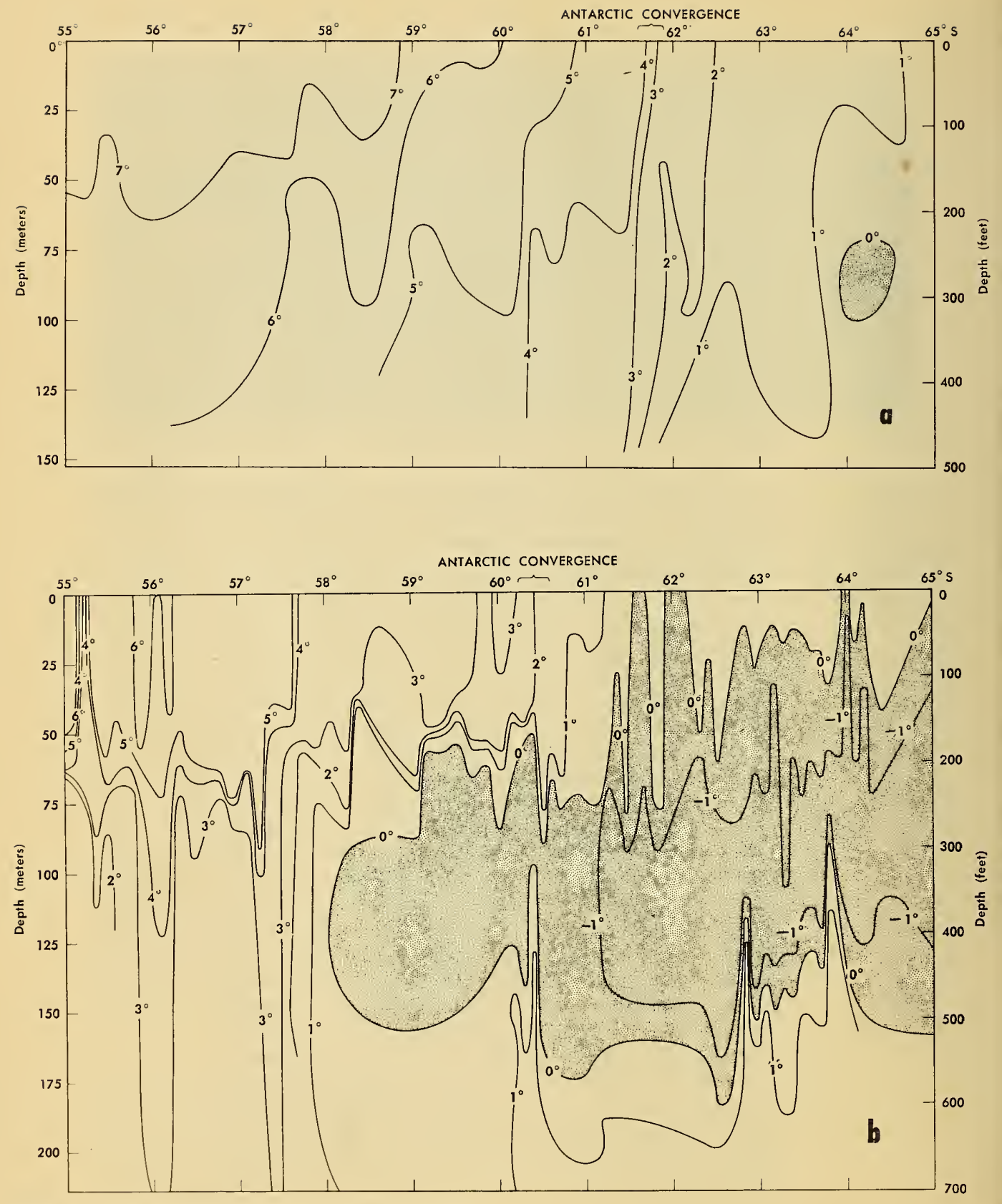

FIGURE 15. Verticol temperature sectians across the Anfarctic Convergence. 
the shaded area of temperatures less than zero degrees C., is well marked in this section. The northern limit of this area occurs just south of the convergence, and serves as a further indication of the location of the boundary zone.

The three vertical sections in figure 16 , sections $\mathrm{C}-1$, $\mathrm{C}-2$, and $\mathrm{C}-3$, all show a fairly well-defined boundary zone at subsurface depths as indicated by the temperature gradients. These sections were all taken approximately along the same north-south line and serve not only to demonstrate the fluctuations with time in the location of the convergence but also show the seasonal development of the subsurface temperature minimum. On vertical section $\mathrm{C}-1$ the structure a short distance south of the convergence shows a nearly isothermal surface layer with temperatures below zero degrees $C$. The increase in temperature in the transition layer at greater depths does not appear here because of the shallowness of the section. Section $\mathrm{C}-2$, taken 54 days later, indicates that the surface heating has produced an area with a well-marked subsurface minimum. The data in this section extended deep enough to penetrate the region of positive gradient. Section C-3 also shows this subsurface minimum and its northern boundary, serving as an indication of the location of the boundary zone.

The southward displacement of the convergence in the 54-day period between section $\mathrm{C}-1$ and $\mathrm{C}-2$ may be related to an increase in the the rmohaline circulation in the subantarctic region, coupled with a decrease in the intensity of the transverse circulation related to the prevailing westerlies in the antarctic region. This displacement appears to be a seasonal phenomenon with the convergence occurring farther south in summer than in the colder months. In winter the cold antarctic water extends farther north along the surface before sinking to form the antarctic intermediate water at the convergence. The northward displacement of the convergence between sections $\mathrm{C}-2$ and $\mathrm{C}-3$ may indicate that the southward seasonal trend has been reversed by late February when section C-3 was obtained. 

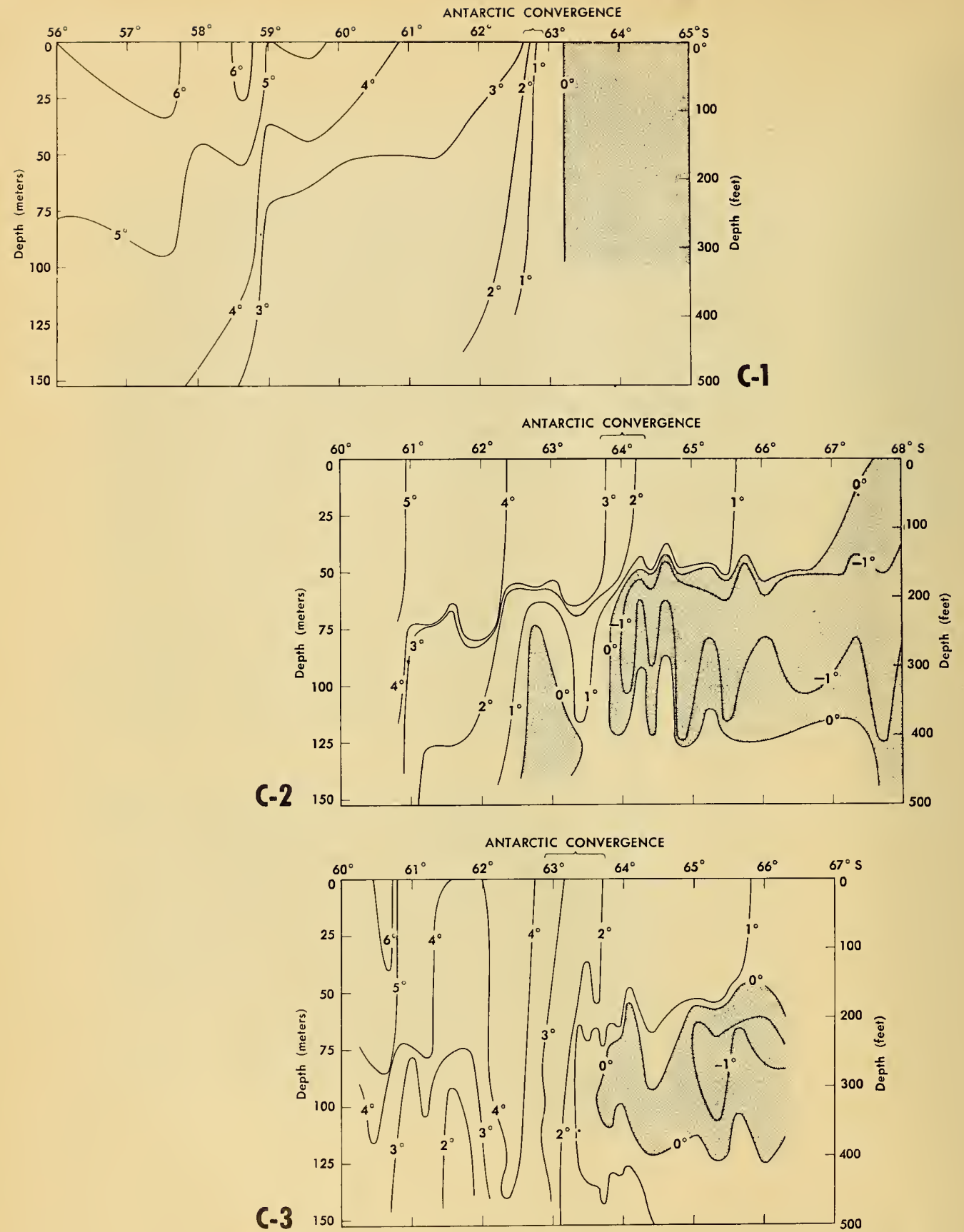

FIGURE 16. Vertical temperature sectians across the Antarctic Canvergence. 
DEPTH OF THE SURFACE LAYER AS AN INDICATION OF SURFACE CURRENTS.

General. The usual procedure in determining the current distribution is to determine the relative mass field from the vertical temperature and salinity distribution. In the absence of sufficient salinity data, it is often possible to obtain an indication of the relative mass field from the depth of the lighter warm surface layer. This results from the fact that in the southern hemisphere the mass field and current field are related in such a manner that the lighter water must occur on the left of the current and the heavier water must occur on the right of the current (observer facing downstream). Hence, in the antarctic the slope of the semidiscontinuity surface at the bottom of the surface layer (top of the thermocline) is associated with a relative current that flows in such a direction that the deeper layer (hence lighter water) is on the left and the shallower layer (hence heavier water) is on the right.

This current-mass field is shown schematically in figure 17 which presents a vertical section taken across a current which is shown as though flowing into the paper. The boundary between the relatively warm surface water and the heavier cold water below the thermocline is shown as sloping upward to the right. Since column $A$ has a greater percentage of light surface water than column $B$, column $B$ will weigh more than column $A$. The conditions requiring the lighter water on the left-hand side of a current in the southern hemisphere are thus satisfied; hence the current flow is at right angles to the section and the direction of flow is into the paper.

Surface Currents from the Observed Temperature Structure. The layer depth was taken as the depth from the surface to the top of the main seasonal thermocline. This depth was averaged for each degree of latitude and longitude, and for some regions, where the number of observations were few, averages were taken over larger areas. The averaging tended to smooth the data and hence to diminish the effect of the small-scale, short-period changes in factors that alter the layer depth (wind force, local heating and cooling, internal waves, etc.), and to emphasize the more widespread, longerperiod trends. 


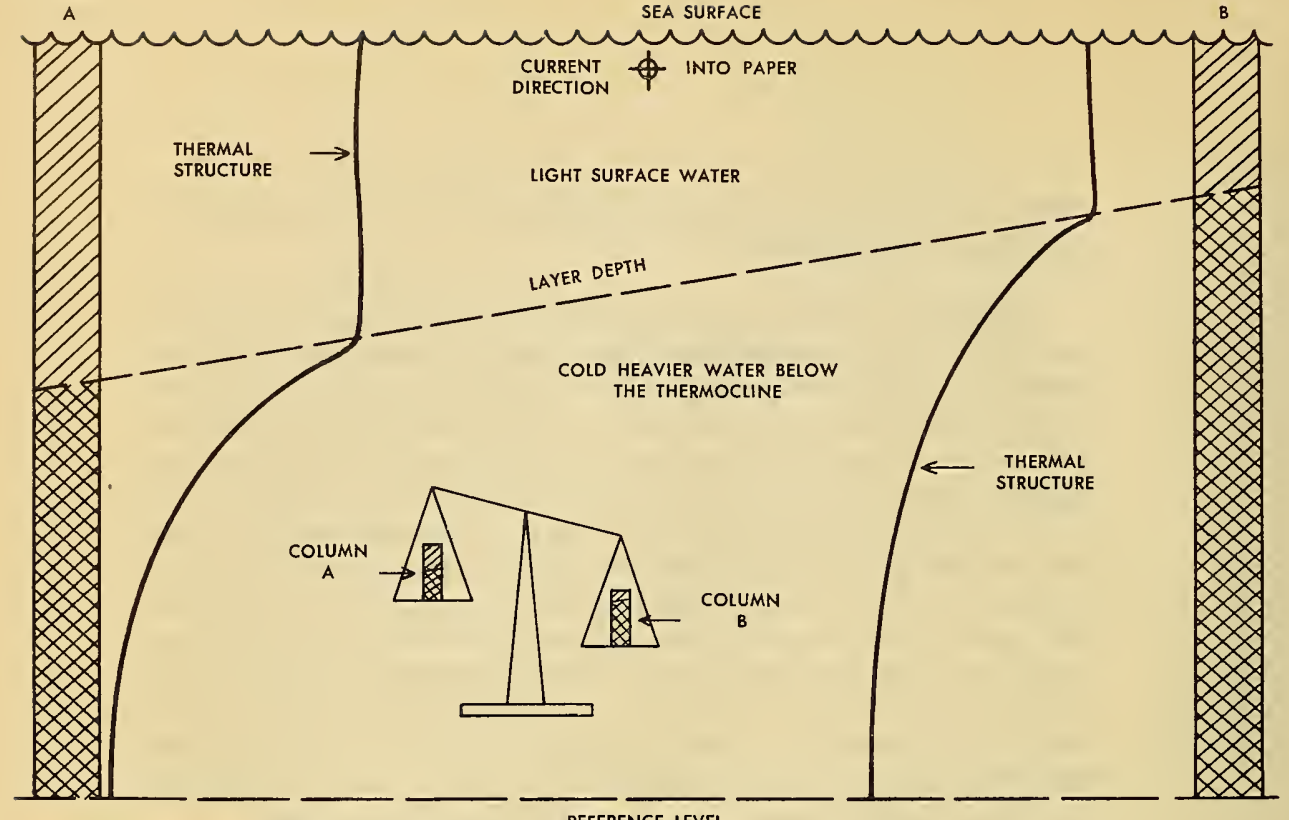

FIGURE 17. Schematic representation of mass field in the sea.

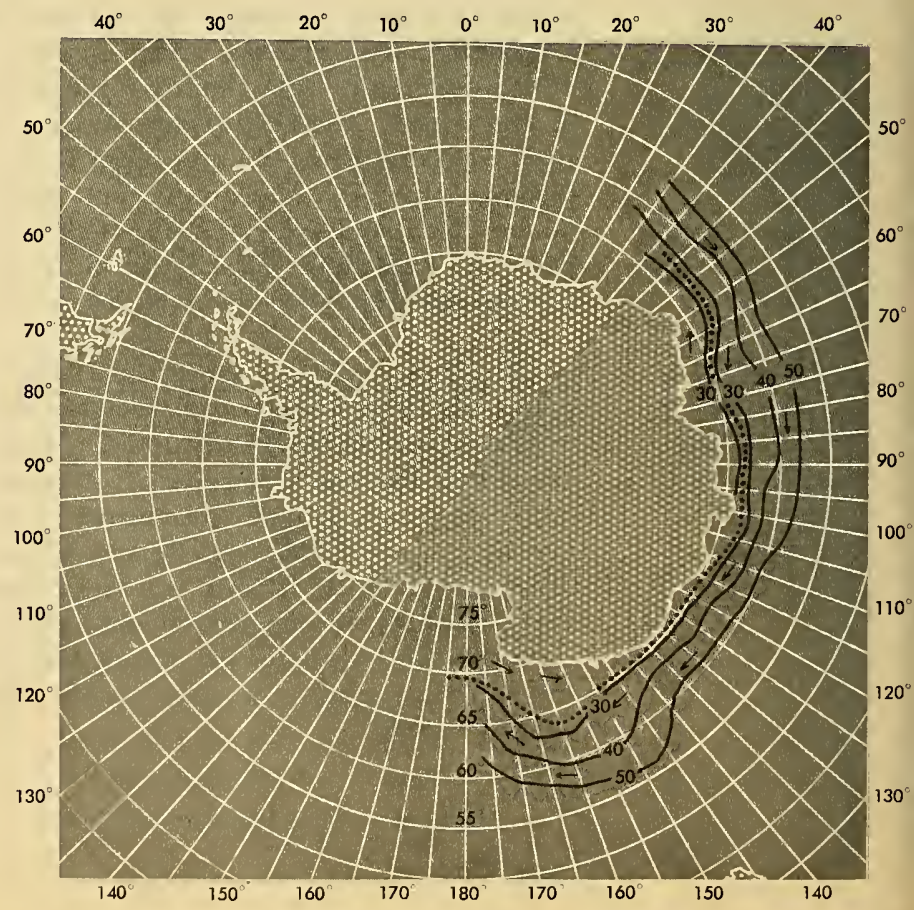


The final averaged values of the layer depth were contoured as shown in figure 18. On the bas is of the theory outlined above, arrows have been entered on the figure paralleling the contour lines and indicating the direction of the flow. The surface current field as thus indicated agrees well with the current field presented in other studies of the antarctic. The trend of the lines of equal layer depth is practically the same as that of the isotherms, indicating that there is little flow across the isotherms. This procedure of deriving surface currents assumes that the salinity effect in the surface layer is small and that the major flow is above the thermocline. In this region these assumptions are sufficiently accurate to give the direction of the surface flow, but uncertainty remains as to the use of this method to obtain current speed.

The location of the boundary between currents which flow in opposite directions should be the location of the minimum layer depth. From figure 18, showing the topography of the layer depth, it is thus seen that there should be a general easterly setting flow north of the area of 30 meters layer depth and a westerly setting flow south of it.

The slope of the discontinuity surface for the easterly flowing current is on the average 0.058 meter per kilometer. This means that the boundary surface sinks 0.058 meter with each kilometer toward the north. For the westward current, the boundary surface sinks on the average 0.055 meter with each kilometer toward the south. 


\section{INTERNAL WAVES}

Bathythermograms obtained from the USS CACOPAN on Operation HIGHJUMP in the antarctic were used to study internal waves. The first series (fig. 19A) was taken at a stationary location $\left(68^{\circ} 16^{\prime} \mathrm{S}, 174^{\circ} 53^{\prime} \mathrm{W}\right)$ which was occupied on 28 and 29 January 1947. Repeated lowerings at this location were made every 10 minutes for the five-hour period, $2135 \mathrm{Z}$ to $0230 Z$. Another series (fig. 19B) was made in the area $67^{\circ} 47^{\prime} \mathrm{S}, 176^{\circ} 54^{\prime} \mathrm{W}$ to $67^{\circ} 40^{\prime} \mathrm{S}, 176^{\circ} 10^{\circ} \mathrm{W}$. Measurements here were made for 2 hours and 20 minutes at five-minute intervals from $0045 \mathrm{Z}$ to $0305 \mathrm{Z}$ on 28 January 1947 .

Whenever repeated bathythermograph observations are made in one locality, the vertical fluctuations of any isotherm is considered to result from internal waves. In order to study them in the antarctic, depths of isotherms were plotted against time. An examination of the bathythermograms revealed that the most suitable temperature was the 30 -degree F. (1.1-degree C.) isotherm because it was continuously in the thermocline.

Many of the bathythermograms showed a double trace in the thermocline. This double trace may be due to hysteres is of the instrument or to the presence of internal waves of very short periods. Only the shoaler trace is used here.

Figure 19A shows variation in the depth of the 30-degree $F$. is otherm at each observation made at 10-minute intervals. The maximum variation in any 10 minutes was 15 feet. In this 5-hour period, the maximum difference between crest and trough for the series was 40 feet.

Figure 19B (the second series of repeated lowerings) shows similar fluctuations due to internal waves for the first 80 minutes at an average depth of 50 feet. Then there is a very sharp drop in the depth of the isotherm to about 140 feet. However, these observations were made while the ship was moving at about 3 knots so it is likely that a boundary between two water masses was crossed. Thus, this increase in the depth of the isotherm is probably not related to internal waves.

Because each station was occupied for only a short time, it is impossible to make any analysis involving the long-period waves such as those related to tidal periods. For the same reason, it would not be profitable to perform a harmonic analysis to determine the dominant periods. 
The bathythermograms collected from the USS CACOPAN prove quite convincingly that internal waves exist in the antarctic region. Long-period waves attained a height of as much as 40 feet in a period of 90 minutes. Many shortperiod waves of about 10,20 , and 30 minutes and with a height of about 10 feet were found to be superimposed on the longer waves.

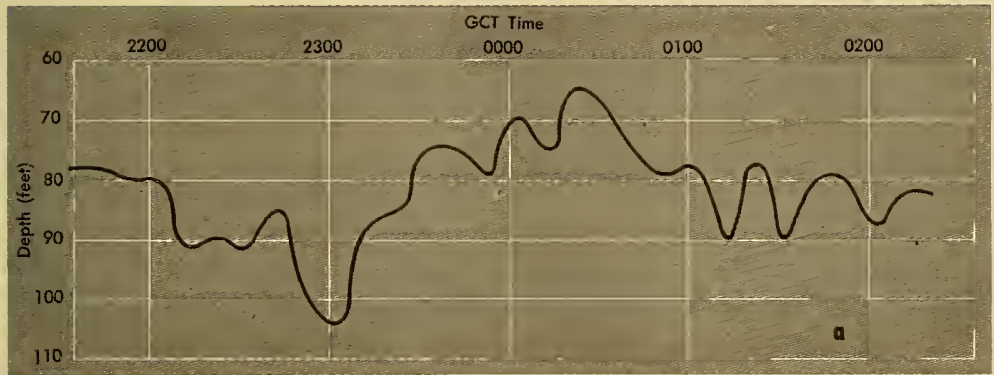

FIGURE 19. Internal waves - vertical fluctuations in the depth af the 30-degree isatherm; data from repeated bathythermograph observations on 28 and 29 January 1947 at twa locatians.

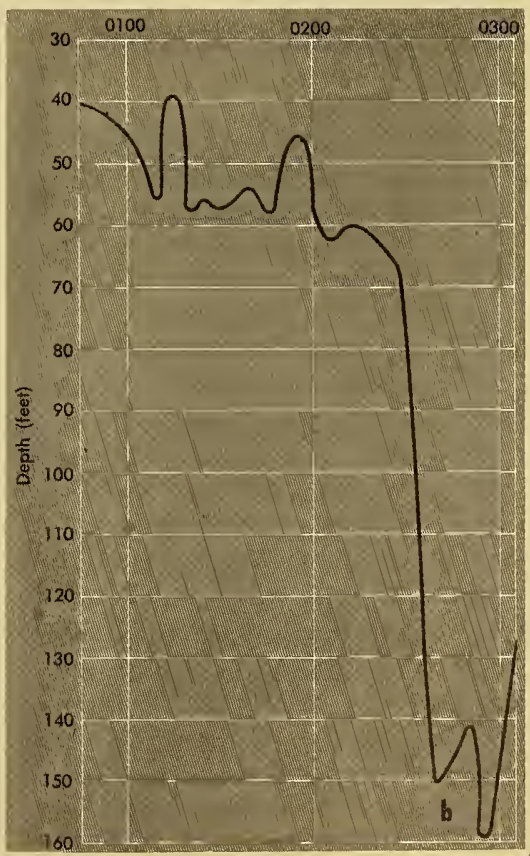


General. During Operation HIGHJUMP, the USS HENDERSON and the USS CACOPAN of the Western Task Group made a number of simultaneous sea temperature and salinity observations to determine the density and buoyancy of the antarctic water. The following is a discussion of these data.

The observations consist of (1) six hydrographic stations taken from the surface to depths of 150 to 250 meters, (2) one station at which observations were made at the surface and at 300 meters only, (3) one station at which observations were made at the surface and at 50 meters only, (4) one station at which a salinity sample was obtained from the water trapped in a coring device at a depth of 2700 meters, and (5) thirty-one surface observations of temperature and salinity from bucket samples. Only those temperature observations made at the same time that salinity samples were taken are included. The positions where the hydrographic stations were occupied are shown in figure 20.

Methods of Collection. The method used in taking these stations differed markedly from the standard procedure. Consideration of this fact should be made when comparing these data to other hydrographic stations where reversing thermometers were used. Reversing thermometers were not used for the stations discussed here. Instead, a bathythermograph and a Nansen bottle were attached to the bathythermograph wires. The temperatures listed in table 8 were then obtained from the temperature-depth trace made by the

FIGURE 20 . Location of hydrographic stations.

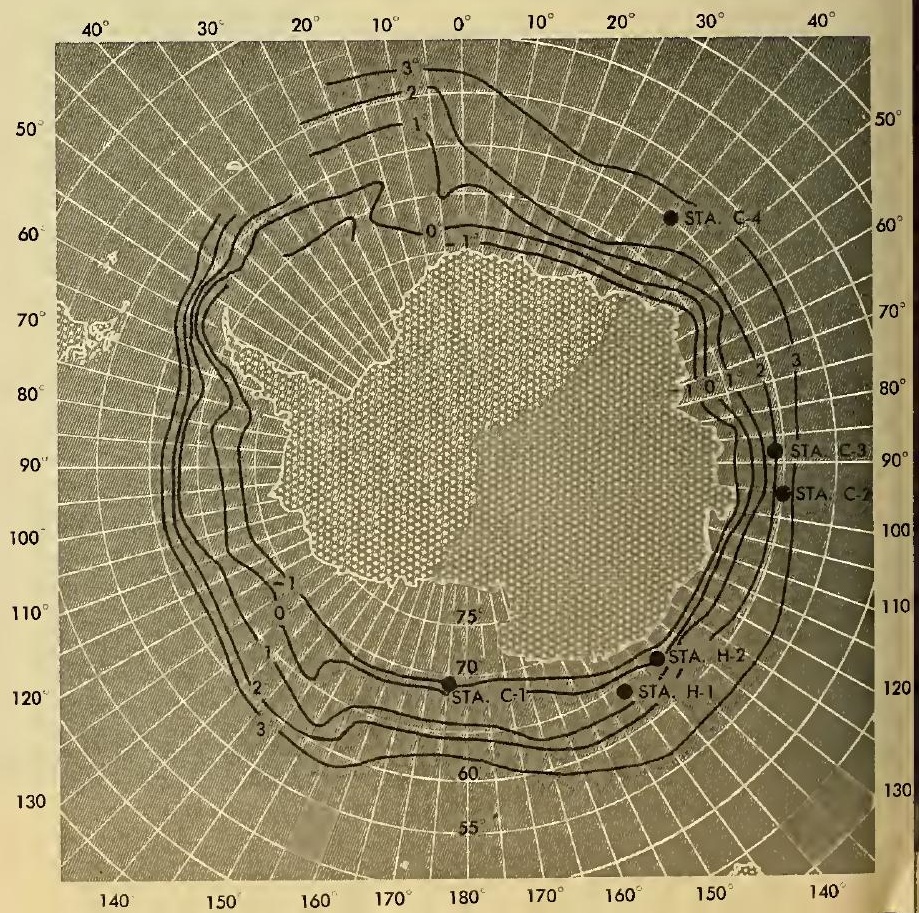


Table 8. Temperature - salinity data.

\begin{tabular}{|c|c|c|c|c|c|c|c|}
\hline \multirow[b]{2}{*}{ STATION } & \multicolumn{3}{|c|}{ OBSERVED VALUES } & \multicolumn{3}{|c|}{ INTERPOLATED VALUES } & \multirow{2}{*}{$\sigma_{t}$} \\
\hline & $\begin{array}{c}\text { Depth } \\
\text { (meters) }\end{array}$ & $\begin{array}{l}\text { Temperciture } \\
\text { (degrees C.) }\end{array}$ & $\begin{array}{c}\text { Salinity } \\
(0 / 00)\end{array}$ & $\begin{array}{c}\text { Depth } \\
\text { (meters) }\end{array}$ & $\begin{array}{l}\text { Temperature } \\
\text { (degrees C.) }\end{array}$ & $\begin{array}{c}\text { Salinity } \\
(0 / 00)\end{array}$ & \\
\hline $\begin{array}{l}\text { Station C-1 } \\
30 \text { January } 1947 \\
0200 \mathrm{GCT} \\
68^{\circ} 43^{\prime} \mathrm{S} 17455^{\prime} \mathrm{W}\end{array}$ & $\begin{array}{r}0 \\
15 \\
30 \\
61 \\
91 \\
152 \\
273\end{array}$ & $\begin{array}{r}-0.5 \\
-1.1 \\
-1.8 \\
-1.6 \\
-1.4 \\
-0.1 \\
+1.2\end{array}$ & $\begin{array}{l}32.90 \\
33.75 \\
34.09 \\
34.23 \\
34.31 \\
3.4 .42 \\
34.55\end{array}$ & $\begin{array}{r}0 \\
10 \\
25 \\
50 \\
75 \\
100 \\
150 \\
200 \\
250 \\
\end{array}$ & $\begin{array}{r}-0.5 \\
-0.5 \\
-1.7 \\
-1.8 \\
-1.5 \\
-1.3 \\
-0.2 \\
+0.6 \\
+1.0 \\
\end{array}$ & $\begin{array}{l}32.50 \\
33.46 \\
3.4 .01 \\
34.20 \\
34.26 \\
34.33 \\
34.42 \\
34.52 \\
34.62 \\
\end{array}$ & $\begin{array}{l}26.46 \\
26.91 \\
27.39 \\
27.56 \\
27.60 \\
27.64 \\
27.67 \\
27.70 \\
27.76 \\
\end{array}$ \\
\hline $\begin{array}{l}\text { Station C-2 } \\
11 \text { Feloruary } 1947 \\
0730 \mathrm{GCT} \\
5955^{\prime} \mathrm{S} \text { ' } 65^{\prime} \mathrm{E}\end{array}$ & $\begin{array}{r}0 \\
15 \\
30 \\
61 \\
91 \\
152 \\
273\end{array}$ & $\begin{array}{r}2.8 \\
2.2 \\
2.8 \\
-0.6 \\
-0.6 \\
1.0 \\
1.6\end{array}$ & $\begin{array}{l}33.80 \\
33.80 \\
33.78 \\
33.96 \\
34.11 \\
34.33 \\
34.36\end{array}$ & $\begin{array}{r}0 \\
10 \\
25 \\
50 \\
75 \\
100 \\
150 \\
200 \\
250 \\
\end{array}$ & $\begin{array}{r}2.8 \\
2.6 \\
2.8 \\
0.2 \\
-0.7 \\
-0.5 \\
1.0 \\
1.3 \\
1.5 \\
\end{array}$ & $\begin{array}{l}33.80 \\
33.10 \\
33.78 \\
33.50 \\
3.4 .03 \\
34.14 \\
34.32 \\
34.35 \\
3.4 .36 \\
\end{array}$ & $\begin{array}{l}26.57 \\
26.97 \\
26.55 \\
27.22 \\
27.38 \\
27.45 \\
27.54 \\
27.52 \\
27.51 \\
\end{array}$ \\
\hline $\begin{array}{l}\text { Station C-3 } \\
13 \text { Fehruary } 1947 \\
1000 \mathrm{GCT} \\
6555^{\prime} \mathrm{S} 85^{-5} 55^{\prime} \mathrm{E}\end{array}$ & $\begin{array}{r}0 \\
15 \\
30 \\
61 \\
91 \\
182\end{array}$ & $\begin{array}{r}2.5 \\
2.5 \\
2.4 \\
-0.3 \\
-1.1 \\
0.6\end{array}$ & $\begin{array}{l}33.02 \\
33.75 \\
33.75 \\
34.04 \\
34.13 \\
34.38\end{array}$ & $\begin{array}{r}0 \\
10 \\
25 \\
50 \\
75 \\
100 \\
150 \\
\end{array}$ & $\begin{array}{r}2.5 \\
2.5 \\
2.4 \\
1.1 \\
-0.9 \\
-1.1 \\
0.0 \\
\end{array}$ & $\begin{array}{l}33.22 \\
33.77 \\
33.74 \\
33.97 \\
34.09 \\
34.14 \\
34.27 \\
\end{array}$ & $\begin{array}{l}27.01 \\
26.96 \\
26.95 \\
27.21 \\
27.43 \\
27.48 \\
27.5 .4\end{array}$ \\
\hline $\begin{array}{l}\text { Stotion C-4 } \\
19 \text { Fohruary } 19.47 \\
0630 \mathrm{GCT} \\
5957^{\prime} \mathrm{S} 40 \quad 30^{\prime} \mathrm{E}\end{array}$ & $\begin{array}{r}0 \\
15 \\
30 \\
61 \\
21 \\
152 \\
197 \\
\end{array}$ & $\begin{array}{r}2.7 \\
2.6 \\
2.4 \\
-1.7 \\
-1.9 \\
-0.3 \\
0.9 \\
\end{array}$ & $\begin{array}{l}33.71 \\
33.63 \\
33.71 \\
34.13 \\
34.16 \\
34.34 \\
34.51 \\
\end{array}$ & $\begin{array}{r}0 \\
10 \\
25 \\
50 \\
75 \\
100 \\
150 \\
\end{array}$ & $\begin{array}{r}2.7 \\
2.6 \\
2.5 \\
-1.2 \\
-1.9 \\
-1.8 \\
-0.3 \\
\end{array}$ & $\begin{array}{l}33.71 \\
33.68 \\
33.68 \\
34.04 \\
34.14 \\
34.18 \\
34.33 \\
\end{array}$ & $\begin{array}{l}26.91 \\
26.50 \\
26.91 \\
27.40 \\
27.50 \\
27.53 \\
27.51 \\
\end{array}$ \\
\hline $\begin{array}{l}\text { Station C-5 } \\
4 \text { January } 1947 \\
0300 \mathrm{GCT} \\
61^{\circ} 13^{\prime} \mathrm{S} \quad 149^{\circ} 20^{\prime} \mathrm{E} \text {. }\end{array}$ & $\begin{array}{r}0 \\
50\end{array}$ & $\begin{array}{l}1.6 \\
0.8\end{array}$ & $\begin{array}{l}33.91 \\
33.77\end{array}$ & & & & $\begin{array}{l}27.15 \\
27.09\end{array}$ \\
\hline $\begin{array}{l}\text { Station C-6 } \\
5 \text { January } 1947 \\
0500 \mathrm{GCT} \\
59^{\circ} 55^{\prime} \mathrm{S} \quad 148^{\circ} 50^{\prime} \mathrm{E}\end{array}$ & $\begin{array}{r}0 \\
300\end{array}$ & 1.3 & $\begin{array}{l}33.78 \\
34.51\end{array}$ & 27 & $\ldots$ & & 27.01 \\
\hline $\begin{array}{l}\text { Station C. }{ }^{*} \\
13 \text { January } 1946 \\
0730 \mathrm{GCT} \\
6015^{\prime} \mathrm{S} 14750^{\prime} \mathrm{E} \\
1650 \text { fathems } \\
\end{array}$ & 2700 & ーேーー & 34.51 & & & & \\
\hline $\begin{array}{l}\text { Station H-1 } \\
6 \text { January } 1947 \\
0300 \mathrm{GCT} \\
63^{\circ} 49^{\prime} \mathrm{S} 146^{\circ} 43^{\prime} \mathrm{E} \\
1750 \text { fathems }\end{array}$ & $\begin{array}{r}0 \\
15 \\
30 \\
61 \\
91 \\
152\end{array}$ & $\begin{array}{r}0.6 \\
-0.1 \\
-0.3 \\
-1.1 \\
-1.2 \\
-0.9\end{array}$ & $\begin{array}{l}33.68 \\
33.65 \\
33.75 \\
34.11 \\
34.16 \\
34.25\end{array}$ & $\begin{array}{r}0 \\
10 \\
25 \\
50 \\
75 \\
100 \\
150 \\
\end{array}$ & $\begin{array}{r}0.6 \\
0.1 \\
-0.2 \\
-0.9 \\
-1.2 \\
-1.2 \\
-0.9 \\
\end{array}$ & $\begin{array}{l}33.68 \\
33.65 \\
33.72 \\
34.03 \\
34.14 \\
34.17 \\
34.25 \\
\end{array}$ & $\begin{array}{l}27.03 \\
27.05 \\
27.11 \\
27.38 \\
27.48 \\
27.51 \\
27.55 \\
\end{array}$ \\
\hline $\begin{array}{l}\text { Etotion } \mathrm{H}-2 \\
16 \text { January } 1947 \\
0730 \mathrm{GCT} \\
6435^{\prime} \mathrm{S} 1355^{\prime}-55^{\prime} \mathrm{E} \\
1300 \text { fathoms }\end{array}$ & $\begin{array}{r}0 \\
15 \\
30 \\
61 \\
91 \\
152\end{array}$ & $\begin{array}{r}0.0 \\
0.0 \\
-0.1 \\
-1.4 \\
-1.6 \\
-1.4\end{array}$ & $\begin{array}{l}33.91 \\
33.29 \\
33.96 \\
34.16 \\
34.22 \\
34.27\end{array}$ & $\begin{array}{r}0 \\
10 \\
25 \\
50 \\
75 \\
100 \\
150\end{array}$ & $\begin{array}{r}0.0 \\
0.0 \\
0.0 \\
-1.1 \\
-1.5 \\
-1.6 \\
-1.5 \\
\end{array}$ & $\begin{array}{l}33.91 \\
33.89 \\
33.92 \\
3.12 \\
34.20 \\
34.23 \\
3.4 .27\end{array}$ & $\begin{array}{l}27.25 \\
27.23 \\
27.25 \\
27.45 \\
27.54 \\
27.56 \\
27.59\end{array}$ \\
\hline
\end{tabular}

* Salinity sample obtained from bottom sampler. 
900-foot bathythermograph and the salinity samples were obtained from the Nansen bottle. The depths of the samples are the length of wire payed out according to the counter on the bathythermograph winch.

Accuracy of Observations. The temperature cannot be read from bathythermograms to a greater accuracy than \pm 0.1 degree $F$.; the instrumental error is estimated at $\pm 0.1 \mathrm{de}-$ gree F. There may also be some difference between the actual depth at which the water sample was taken and the depth at which the bathythermogram was read. It is thus probable that the temperatures corresponding to salinities given here are accurate to about 0.1 degree $C$. The depths at which the water samples were obtained from the counter of the bathythermograph winch are fairly accurate at shallow depths.

The water samples were titrated with silver nitrate by the Knudsen method ${ }^{2}$ to determine chlorinity and salinity. The salinities are expressed in parts per thousand $(0 / 00)$ and are accurate to $0.02 \% / 00$.

The density of the water was calculated from the temperature and the salinity by means of Knudsen's Tables. 3 In discussing density in this report the common notation, $\sigma_{t}$, will be used. This density is defined by the relation:

$$
\sigma_{t}=1000\left(\rho_{\theta, s, 0}-1\right)
$$

where $\rho \theta, s, o$ is the density of a parcel of water of salinity $s$, temperature $\theta$, and pressure 0 (one atmosphere). Because of the low temperature range encountered, the 0.1 -degree $C$. error does not introduce a serious error in the computed density. Within the temperature and salinity range encountered, the probable error in temperature corresponds to an error of less than 0.01 in $\sigma_{t}$.

Results. Earlier in this report, there is a discussion of the results of temperature observations made with bathythermograms. The general conclusions which apply to the over-all temperature structure (as given in the bathythermogram discussion) apply also to the temperature distributions that are presented here. The temperature-depth structure for the six hydrographic stations is shown in figure 21 . In general, these temperature traces show certain characteristic trends. At all stations, except station $\mathrm{C}-1$, a minimum 
temperature layer appears between 50 and 100 meters. The temperatures both above and below this layer are from 1 to 2 degrees C. warmer than in the cold layer (referred to earlier as type S-1 thermal structure). At stations C-2, $\mathrm{C}-3$, and $\mathrm{C}-4$, the warming of the upper laye $r$ is especially well-marked. An explanation of the processes leading to this type of temperature distribution has been discussed in the section: "Thermal Structure of the Surface Layers in the Antarctic Ocean."

FIGURE 21. Vertical thermal structure at hydrographic stations.

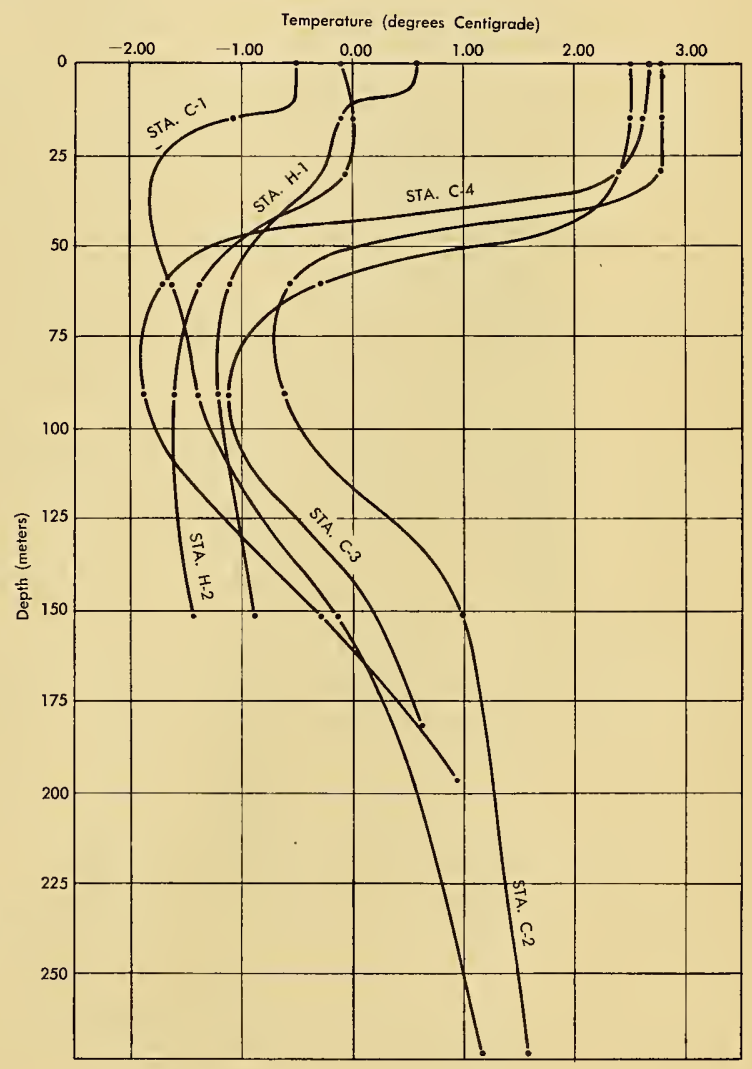


In winter, intense cooling results in a virtually homogeneous layer of water about 100 meters ( 300 feet) thick. On the basis of winter observations in this region, this layer has a temperature that is near freezing. Below this mixed layer, increasing salinity allows for an increase in temperature without resulting in instability. According to Sverdrup, Johnson, and Fleming, ${ }^{4}$ antarctic circumpolar water, which occurs a short distance below the surface water, is characterized by a temperature maximum at a depth of 500 to 600 meters.

In summer, the radiation surplus is first used to melt the ice and next to increase the temperature of the surface layers. Station C-1, which was occupied in the Ross Sea fairly close to the ice pack, shows a temperature minimum at a depth of only 35 meters, compared to approximately 75 meters for the other stations. The increase of temperature above 35 meters is much less than in the other cases, indicating that in this region the radiation surplus had apparently been used mainly for melting the ice.

The relatively high temperature of the surface layer above 45 meters ( 150 feet) in the five hydrographic stations other than C-1 must be largely the result of actual heating of the surface layers. There is some indication that stations $\mathrm{C}-2, \mathrm{C}-3$, and $\mathrm{C}-4$ were taken near the Antarctic Convergence, hence the high temperatures found on the surface at these stations may be partly due to the southward intrusion of a thin surface layer of warm water from north of the convergence. The stability which is associated with the strong negative gradients thus developed aids in restricting this warm layer to the upper 150 feet.

The minimum temperatures found at all stations from 60 to 100 meters (200 to 300 feet) must the refore be the remainder of the winter-cooled surface layer mentioned above. The increase in temperature that occurs below 100 meters at the different stations evidently corresponds to the transition layer between surface water and antarctic circumpolar water, which has a maximum temperature of between 2.0 and 2.5 degrees C. at depths from 500 to 600 meters.

Figure 22 gives the salinity-depth curves for all stations. These curves also show certain characteristics which tend to support the conclusions gained from the thermal structures. The melting of ice results in lowered salinities very near the surface. This low salinity layer is shown best at station C-1, 
which was taken near the ice pack. The surface salinity at this station was 32.90 , as compared with an average surface salinity of 33.80 for the other five stations. The salinity distribution in the summer thus aids in establishing stability in the upper layers. This stability restricts the heating in the ice-free areas to the upper 45 meters ( $150 \mathrm{feet}$ ) and leaves the winter-cooled layer just below this depth at temperatures near freezing. At all stations the salinity at 300 feet lies between 34.0 and $34.5 \mathrm{o} / \mathrm{oo}$ which corresponds to the types of water found in the cooled layer in winter.

FIGURE 22. Vertical salinity structure at hydrographic stations.

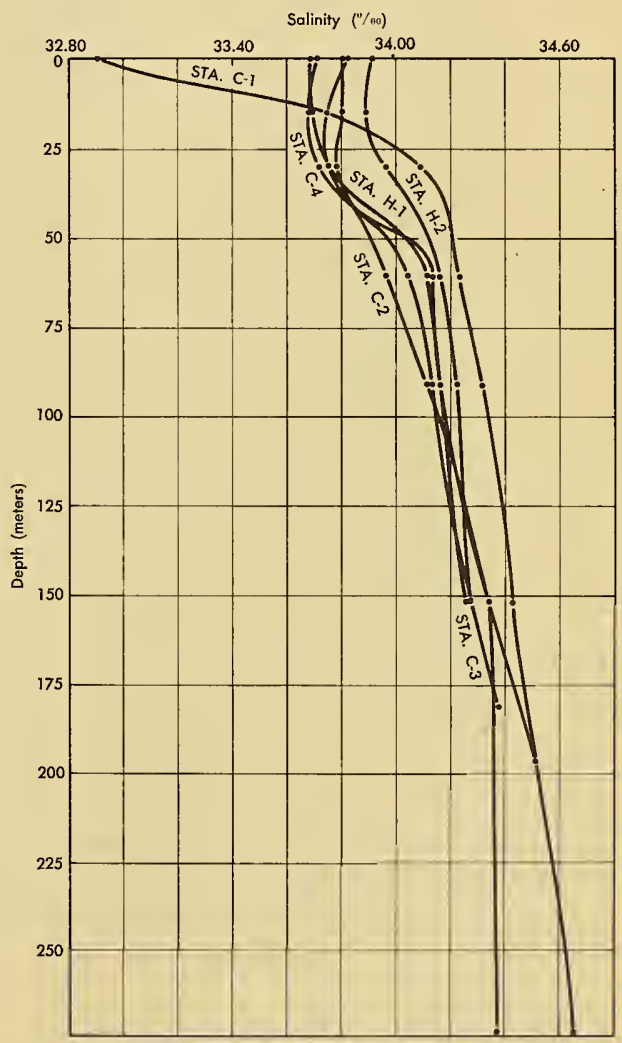


The temperature-salinity diagrams in figure 23 further substantiate the conditions described above. The characteristic temperature minimum is evident on all the $\mathrm{T}-\mathrm{S}$ curves. This minimum, which occurs very close to -1.0 degree $C$. and between 34.1 and 34.2 o/oo, corresponds to the layer of wintercooled water. Surface heating and low salinity are indicated by the sharp rise in the curves at the left of the temperature minimum. At station $\mathrm{C}-1$ the elongation of the $\mathrm{T}-\mathrm{S}$ curve on the left shows the effect of dilution caused by the melting of ice. The approximate $T-S$ value of antarctic circumpolar water at 600 meters for the region within which the stations were occupied is plotted as a large dot labeled "A.C.P.W." It can be seen that the increase of temperature and salinity with depth below 100 meters tends to bring the $\mathrm{T}-\mathrm{S}$ curves toward this point.

The density structure, as represented by the curves of figure 24 , indicates instability or indifferent equilibrium in the upper 30 meters except at stations $\mathrm{C}-1$ and $\mathrm{H}-1$. Station $\mathrm{H}-1$ shows slight stability, while station $\mathrm{C}-1$ shows marked stability, in this layer. There is generally a moderate increase in density in the 30- to 60-meter laye $r$, the increase leading to moderate stability at these depths. Below 60 meters there is only slight stability.

The effect of this density structure on submarine diving operations is indicated in figure 25 . The amount of buoyancy change required in diving from a depth of 50 feet to any depth down to 300 feet has been computed for a 2400-ton submarine using the diving rule of 1400 pounds per 100 .feet. These figures were computed on the basis of a 5400 pound change in buoyancy for each unit change in $\sigma_{t}$. At stations $\mathrm{C}-1$ and $\mathrm{C}-4$, the computed buoyancies indicate that flooding is necessary to go from 50 feet to 150 feet. At station C-1, a submarine at 50 feet would be in the center of a sharp density layer. At station C-4 there is a fairly sharp density layer, approximately 2000 pounds per 100 feet between 125 and 175 feet. At the other four stations no appreciable density laye $r$ is indicated. These data indicate that relatively little flooding or pumping is needed for diving operations in the antarctic. 
Table 9. Surface temperatures, salinities, and temperature values.

\begin{tabular}{|c|c|c|c|c|c|c|c|c|c|}
\hline Serial No. & & Date & & $\begin{array}{l}\text { Time } \\
\text { (GCT) }\end{array}$ & Latitude & Longitude & $\begin{array}{l}\text { Temperature } \\
\text { (degrees C.) }\end{array}$ & $\begin{array}{l}\text { Salinity } \\
(\% / 00)\end{array}$ & $\sigma_{t}$ \\
\hline 1 & 28 & Dec & 46 & 0230 & $6212^{\prime} \mathrm{S}$ & $162^{\prime} 15^{\prime} \mathrm{E}$ & -0.3 & 33.78 & 27.16 \\
\hline 2 & 29 & Dec & 46 & 0430 & $6340^{\prime}$ & $16211^{\prime}$ & 0.0 & 33.42 & 26.85 \\
\hline 3 & 29 & Dec & 46 & 2000 & $6223^{\prime}$ & $159^{\circ} 32^{\prime}$ & 0.7 & 33.58 & 26.95 \\
\hline 4 & 30 & Dec & 46 & 0200 & $61^{4} 46^{\prime}$ & $156^{\circ} 14^{\prime}$ & 1.7 & 33.78 & 27.04 \\
\hline 5 & 31 & Dec & 46 & 0300 & $5920^{\prime}$ & $15203^{\prime}$ & 1.8 & 33.86 & 27.09 \\
\hline 6 & 4 & Jan & 47 & 0300 & $61^{\circ} 13^{\prime}$ & $14920^{\prime}$ & 1.6 & 33.71 & 27.15 \\
\hline 7 & 5 & Jen & 47 & 0500 & $59^{\circ} 55^{\prime}$ & $140^{\circ} 50^{\prime}$ & 1.3 & 33.78 & 27.07 \\
\hline 8 & 6 & Jan & 47 & 0300 & $63^{\circ} 49^{\prime}$ & $146^{\circ}+3^{\prime}$ & 0.6 & 33.68 & 27.03 \\
\hline 9 & 16 & Jan & 47 & 0730 & $64^{\circ} 38^{\prime}$ & $135.55^{\prime}$ & 0.0 & 33.91 & 27.25 \\
\hline 10 & 18 & Jan & 47 & 0400 & $61^{\circ} 03^{\prime}$ & $140^{\circ} 0^{\prime}$ & 2.3 & 33.78 & 27.00 \\
\hline 11 & 20 & Jan & 47 & 0130 & $60^{\circ} 58^{\prime}$ & $135^{\circ} 17^{\prime}$ & 1.8 & 33.78 & 27.03 \\
\hline 12 & 21 & Jan & 47 & 2330 & $65^{\circ} 43^{\prime}$ & $14135^{\prime}$ & -0.4 & 33.73 & 27.12 \\
\hline 13 & 23 & Jon & 47 & 0630 & $64^{\circ} 30^{\prime}$ & $156^{\circ} 00^{\prime}$ & 0.8 & 32.90 & 26.39 \\
\hline 14 & 24 & Jan & 47 & 2300 & $65^{\circ} 27^{\prime}$ & $175^{\circ} 08^{\prime}$ & 2.0 & 3.4 .07 & 27.25 \\
\hline 15 & 26 & Jan & 47 & 2330 & $66^{\circ} 55^{\prime}$ & $17348^{\prime} \mathrm{W}$ & 1.6 & 34.02 & 27.24 \\
\hline 16 & 28 & Jan & 47 & 1030 & $68^{\circ} 04^{\prime}$ & $17440^{\prime}$ & 0.0 & 33.10 & 26.60 \\
\hline 17 & 30 & Jan & 47 & $0200^{\circ}$ & $68^{\circ} 43^{\prime}$ & $17.455^{\prime}$ & -0.5 & 32.90 & 26.46 \\
\hline 18 & 7 & Feb & 47 & 0800 & $63^{\circ} 27^{\prime}$ & $12150^{\prime} \mathrm{E}$ & 0.9 & 33.93 & 27.21 \\
\hline 19 & 11 & Feb & 47 & 0730 & $59^{\circ} 55^{\prime}$ & $96^{\circ} 45^{\prime}$ & 2.8 & 33.80 & 26.97 \\
\hline 20 & 13 & Fels & .47 & 1000 & $60^{\circ} 55^{\prime}$ & $88^{\circ} 55^{\prime}$ & 2.5 & 33.82 & 27.01 \\
\hline 21 . & 18 & Feb & 47 & 0630 & $59^{\circ} 57^{\prime}$ & $40^{2} 30^{\prime}$ & 2.7 & 33.71 & 26.91 \\
\hline 22 & 21 & Fob & 47 & 1430 & $60^{\circ} 45^{\prime}$ & $29^{\circ} 45^{\circ}$ & 2.8 & 33.66 & 26.86 \\
\hline 23 & 2 & Mar & 47 & 1100 & $63^{\circ} 55^{\prime}$ & $82^{\circ} 2 v^{\prime}$ & -0.8 & 32.43 & 26.09 \\
\hline 24 & $\ell$ & Mar & 47 & - & $63^{\circ} 27^{\prime}$ & $115^{\circ} 4 \overline{0}^{\prime}$ & 3.5 & 33.22 & 26.92 \\
\hline 25 & 6 & Mar & 47 & 0900 & $55^{\circ} 55^{\prime}$ & $11735^{\prime}$ & 4.3 & 33.82 & 26.84 \\
\hline 26 & 7 & Mar & 47 & 0600 & $53^{\circ} 22^{\prime}$ & $12440^{\prime}$ & 5.7 & 33.80 & 26.68 \\
\hline 27 & 8 & Mar & 47 & 0100 & $47^{\circ} 20^{\prime}$ & $13533^{\prime}$ & 6.8 & 34.13 & 26.49 \\
\hline 28 & 9 & Mer & 47 & 0900 & $46^{\circ} 08^{\prime}$ & $13630^{\circ}$ & 10.6 & $34 . \$ 2$ & 26.42 \\
\hline 29 & 10 & Mar & 47 & 1430 & $40^{\circ} 15^{\prime}$ & $14305^{\prime}$ & 16.4 & 35.21 & 25.83 \\
\hline 30 & 11 & Mar & 47 & 0000 & $39^{\circ} 30^{\prime}$ & $144^{\circ} 12^{\prime}$ & 17.3 & 35.30 & 25.70 \\
\hline 31 & 22 & Mar & 47 & 0700 & $32^{\circ} 67^{\prime}$ & $16500^{\prime}$ & 21.5 & 35.64 & 24.86 \\
\hline 32 & 23 & Mer & 47 & 0300 & $29^{\circ} 54^{\prime}$ & $170^{\circ} 03^{\prime}$ & 23.3 & 35.75 & 24.43 \\
\hline 33 & 24 & Mar & 47 & 0600 & $26^{\circ} 17^{\prime}$ & $175^{-35^{\prime}}$ & 23.6 & 35.53 & 24.18 \\
\hline 34 & 25 & Mer & 47 & 0400 & $22^{\circ} 36^{\prime}$ & $179.40^{\prime} \mathrm{W}$ & 26.5 & 25.32 & 23.14 \\
\hline 35 & 26 & Mor & 47 & 0500 & $18^{\circ} 24^{\prime}$ & $17455^{\prime}$ & 28.3 & 35.03 & 22.33 \\
\hline 36 & 27 & Mar & 47 & 0600 & $14^{\circ} 10^{\prime}$ & $170^{\circ} 20^{\prime}$ & $2 ; .6$ & 34.65 & 21.64 \\
\hline 37 & 28 & Mar & 47 & 0600 & $09^{\circ} 57^{\prime}$ & $.165^{\circ} 55^{\prime}$ & 25.1 & 34.70 & 21.82 \\
\hline 38 & 29 & Mar & 47 & 2000 & $03^{\circ} 28^{\prime}$ & $159^{\circ} 32^{\prime}$ & 27.0 & 35.37 & 23.02 \\
\hline 39 & 30 & Mar & 47 & 2200 & $01^{\circ} 37^{\prime} \mathrm{N}$ & $154^{\circ} 54^{\prime}$ & 26.9 & 34.90 & 22.68 \\
\hline
\end{tabular}


Water transparency measurements were made from the USS CACOPAN at fifteen different stations in the antarctic. The transparency measurements were made with the aid of a Secchi disk (a white disk 30 centimeters in diameter). The Secchi disk was lowered into the water in a horizontal position and the maximum depth at which the disk was still visible was noted. This depth was taken as a measure of the transparency.

In the Antarctic Ocean the Secchi disk readings (table 10) vary from 23 to 90 feet with an average of 50 feet. Most of the measurements are similar to the average transparencies for open-sea conditions. But the readings between 23 and 32 feet at four of the stations are very low transparencies for open-sea conditions. The low transparency is probably related to high phytoplankton production.

Both the color of the sea and the surface temperature were noted at the same time that the transparency measurement was made (see table 10). Antarctic water is typically blue-gray, blue-green, or green. Near the pack ice the water is usually green and of low transparency owing to high organic content. On $19 \mathrm{February}$ a tongue of bright blue water was encountered which appeared to be a tongue of Indian Ocean water that extended into the antarctic.

\section{ANTARCTIC "SEEING"}

Especially impressive during Operation HIGFJUMP was the crystal clearness of some of the antarctic days, the stellar brilliance of some of the nights, and the consequent fitness of these regions for making celestial observations even from sea-level elevation.

Polar regions are noted for many curious optical phenomena, most of which are related to excellent visibility rather than to optical distortion. It is well known that, because of atmospheric clarity, the mariner and the explorer in high latitudes frequently underestimate distances by as much as 50 miles and occasionally by as much as 200 or 300 miles when superior mirages or loomings a re involved. Regarding celestial observations, Byrd 5 states that observers at Little America noted as many as 60 meteors per minute. He attributes such exceptionally high counts to the clarity of the sky which permitted the sighting of faint trails that would be invisible in other parts of the world. 
Table 10. Antarctic Ocean transparency (Secchi Disk) measurements.

\begin{tabular}{|c|c|c|c|c|c|c|c|c|c|c|}
\hline No. & LCT & $\begin{array}{l}\text { Time } \\
\text { Zone }\end{array}$ & & Date & & Latitude & Longitude & $\begin{array}{c}\text { Surface } \\
\text { Water } \\
\text { Temperature } \\
\text { (degrees F.) }\end{array}$ & Water Color & $\begin{array}{c}\text { Transparency } \\
\text { (feet) }\end{array}$ \\
\hline 1 & 1330 & 11 & 28 & Dec & 46 & $6412^{\prime} \mathrm{S}$ & $162^{\prime} 15^{\prime} \mathrm{E}$ & 31.4 & Green & 43 \\
\hline 2 & 1600 & 11 & 28 & Dec & 46 & $6409^{\prime}$ & $162^{\circ} 15^{\prime}$ & 30.8 & Blue-Green & 42 \\
\hline 3 & 0830 & 11 & 30 & Dec & 46 & $6213^{\prime}$ & $159^{\circ} 11^{\prime}$ & 33.9 & Blue-Gray & 40 \\
\hline 4 & 1500 & 11 & 1 & Jan & 47 & $5906^{\prime}$ & $150^{\prime} 17^{\prime}$ & 34.6 & Blue-Grey & 24 \\
\hline 5 & 1330 & 12 & 4 & Jan & 47 & $6024^{\prime}$ & $15045^{\prime}$ & 34.8 & Slue & 81 \\
\hline 6 & 1500 & 12 & 5 & Jen & 47 & $5955^{\prime}$ & $148^{\circ} 50^{\prime}$ & 34.3 & Blue-Groy & 23 \\
\hline 7 & 1330 & 12 & 30 & Jan & 47 & $68^{\circ} 43^{\prime}$ & $17455^{\prime} \mathrm{W}$ & 30,9 & Blue-Gray & 90 \\
\hline 8 & 1300 & 11 & 11 & Fob & 47 & $5955^{\prime}$ & $965^{\prime} \mathrm{E}$ & 36.8 & Blue-Gray & 55 \\
\hline 9 & 1530 & 6 & 13 & Feb & 47 & $60^{\prime} 55^{\prime}$ & AB $55^{\prime}$ & 36.5 & Bluc-Gray & 41 \\
\hline 10 & 1230 & 6 & 14 & Felo & 47 & $60^{\circ} 52^{\prime}$ & $8430^{\prime}$ & 35.3 & Green & 23 \\
\hline 11 & 0915 & 4 & 19 & Fob & 47 & $5957^{\prime}$ & $4030^{\prime}$ & 36.3 & Bright Blue & 68 \\
\hline 12 & 1300 & 4 & 20 & Feb & 47 & $611^{\circ} 14^{\prime}$ & $3740^{\prime}$ & 37.5 & Blue & 85 \\
\hline 13 & 1630 & 3 & 21 & Feb & 47 & $60^{\circ} 45^{\circ}$ & $29^{\circ} 45^{\prime}$ & 37.2 & Blue-Groy & 55 \\
\hline 14 & 1300 & 4 & 25 & Fob & 47 & $6018^{\prime}$ & $47^{\circ} 45^{\prime}$ & 37.4 & $-1-1=$ & 47 \\
\hline 15 & 1700 & 6 & 2 & Mar & 47 & $63^{\circ} 55^{\prime}$ & $8220^{\circ}$ & 30.6 & $\begin{array}{l}\text { Green (at edge } \\
\text { of ice pack) }\end{array}$ & 32 \\
\hline
\end{tabular}

On clear days, icebergs stand out with such definition that one feels he might reach out and touch them although they are obviously many miles away. The topmost portion of large bergs can still be seen when the base is so distant that curvature of the earth causes it to appear well below the horizon. The sun, which sets with little distortion or change in color, is so brilliant that one cannot look directly at it until it has almost entirely disappeared below the horizon.

Even more impressive than the clarity of some of the antarctic days, is the atmospheric transparency of many of the antarctic nights. A strong beam of light is invisible because of the absence of the Tyndall effect as there are no solid particles in the air to scatter light. Stars shine brilliantly and can be seen down almost as far as the horizon. Most surprising is the fact that the stars shine with a bright steady light and do not twinkle. All of this adds up to excellent "seeing" -- probably unsurpassed anywhere in the world.

This excellent "seeing" in the antarctic region is largely understandable. As these regions are uninhabited areas of water and ice, there is practically no source for inorganic or organic dust particles, or for pollution by smoke. A permanent high pressure area lies over Antarctica, so that cold, dry, and consequently haze-free air flows radially outward from the continent. Strong temperature inversions cause the air to be stable and the airflow to be laminar. 
FIGURE 26. Portion of a typical "youthful" tabular ontorctic iceberg. Recent formation of this berg by break. ing off from shelf ice is indicated since there are, as yet, no sea caves or other evidence of sea weathering developed along the waterline.
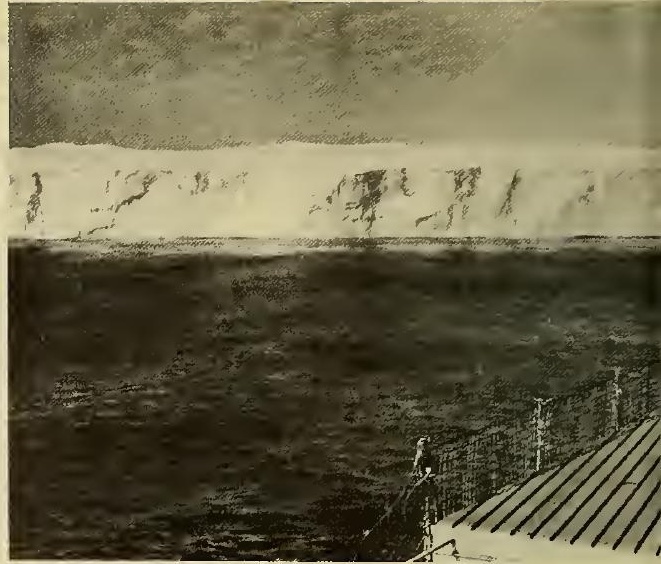

FIGURE 27. View of a typical pyramidy iceberg. This has the form of a moderately weothered "mature" berg. Nate the tilted and uplifted shoreline produced by a calving which changed the center of gravity. 
Observations from aboard ship show a low percentage of clear days but aircraft pilots usually reported good weather over the continent and their aerial photographs show high atmospheric transparency. Thus it seems that astronomers should take an active interest in investigating portions of the Antarctic Continent for possible use in making astronomical observations. Perhaps the ice-free "oases" recently dis covered by the Navy near the Antarctic Circle would furnish satisfactory bases. Along with excellent "seeing," the long winter night permits uninterrupted observations and long photographic exposures.

\section{ICEBERGS AND SEA ICE}

On 23 December 1946 the HENDERSON crossed the Antarctic Convergence and entered the polar water mass. The well-marked boundary of this water mass was very apparent. While running about 20 miles, the surface water bucket temperatures dropped abruptly from 39 to 33 degrees F. A similar abrupt temperature drop when crossing this boundary was revealed when the injection temperatures of both the CURRITUCK and the CACOPAN were checked. The change from blue to gray in the color of the water, the appearance of new types of birds, the clearing of the sky, and the quieting of the sea were other striking observations that were noted.

The HENDERSON left the convergence and had traveled about 25 miles in a southerly direction when the ship encountered the first iceberg; this berg was one of a large field of bergs that extended to the south. Throughout the entire antarctic passage, the bergs were seldom observed to be isolated; they appeared rather to be collected into fields. The northernmost limit of bergs as noted by the CACOPAN was roughly $60^{\circ} \mathrm{S}$. Distribution of both bergs and pack ice as noted by the HENDERSON is shown in figure 1 .

As antarctic bergs are formed largely by the calving of shelf ice, they are typically tabular in shape (fig. 26). However, melting and wave erosion result in the formation of an ice foot and of sea caves along the waterline and, after much weathering, the bergs begin to lose their original tabular form. They become pyramidy (fig. 27) and often are grotesquely carved. Pyramidy bergs frequently display uplifted and tilted waterlines formed by calving which results in a sudden change in the center of mass. 


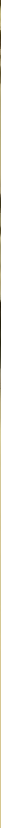

FIGURE 28. Newly farmed pads af pancake sea ice a few feet acrass as viewed from the deck of the USS CURRITUCK after a few doys of below-freezing weather.

When the ship was lying to near the pack, icebergs sometimes appeared to be plowing through the sea ice because, as is well known, bergs are usually current driven while sea ice is wind driven. For this reason the bergs may move at a different rate from that of the sea ice and often move in a different direction. This is related to the deep draft of the bergs and especially to their great mass because, relative to sea ice, bergs have a small surface area for the wind to act on as compared to their mass.

During the last few days of February, the temperature, which had been continuously above freezing, dropped to a little below freezing and pancake ice formed. This presaged the growth of the ice pack and the coming of winter. The freezing of sea water is markedly different from that of fresh water. Fine needles of ice form slightly below the surface and then float to the surface producing a slush. After slight surface buffeting and further freezing, this slush is transformed into "lily pads" of pancake ice (see fig. 28). 
ANTARCTIC SEA FLOOR SEDIMENTS*

Three core samples (see table 11) were obtained in the antarctic by means of a gravity coring device of the type described by Emery and Dietz. Because the small wire size limited the weight of the sampler, however, and because the oceanographic winch did not permit the wire to be lowered rapidly, only a small impact force could be obtained. Consequently, the three cores collected were of short length.

Two earlier attempts had been made to secure bottom cores; however, these attempts were both unsuccessful. The bottom could not be reached largely because the makes hift oceanographic winch was unsatisfactory. It consisted of a spool which was welded to a large warping winch of the CACOPAN and which held 4500 meters of 5/32-inch, $7 \times 7$ strand wire. The very slow speed at which the wire could be lowered and the rapid drift of the ship resulted in large wire angles and excessive wire strain. After the two unsuccessful attempts, bottom was finally reached on the top of a deep ridge by intermittently backing down the ship at one-third speed to reduce the wire angle. The four or five hours necessary to obtain a core sample in deep water was excessive, so there were few opportunities to attempt abyssal bottom sampling. And, unfortunately, the entire Antarctic track of the CACOPAN was in deep water.

\footnotetext{
* The samples are only briefly described here since a detailed mineralogical study is being made separately by J. L. Hough, presently of the University of Illinois; in addition, an investigation of the foraminiferal fauna is being made separately by Miss M. Bradley at the University of Southern California.
}

Table 11. Sediment samples obtained from the USS CACOPAN on Operation HIGHJUMP.

\begin{tabular}{|c|c|c|c|c|c|c|}
\hline $\begin{array}{l}\text { Date } \\
(1947)\end{array}$ & $\begin{array}{c}\text { Sample } \\
\text { No. }\end{array}$ & Latitude & Longitude & $\begin{array}{l}\text { Sonic Depth } \\
\text { (fathoms) }\end{array}$ & $\begin{array}{c}\text { Sampling } \\
\text { Device }\end{array}$ & Remarks \\
\hline NEL 394 & 13 Jen & $60^{\circ} 13^{\prime} 5$ & $147^{\circ} 45^{\prime} \mathrm{E}$ & 1300 & Corer & $\begin{array}{l}\text { Diatomoceous globigerina osze; } 19 \text { in. } \\
\text { core; from top of submorine ridge } \\
\text { (Indion-Anterctic Swal). }\end{array}$ \\
\hline NEL 395 & 14 Fob & $60^{\circ} 55^{\prime}$ & $84^{\circ} 30^{\prime}$ & 1400 & Corer & $\begin{array}{l}\text { Diatemoceous globigerino o6zo; top of } \\
\text { Gaussberg-Kerguelen. Ridge; smol } \\
\text { sample as mast of cor. Woshed out. }\end{array}$ \\
\hline NEL 396 & 2 Mar & $6355^{\prime}$ & $8220^{\prime}$ & 1980 & Corer & $\begin{array}{l}\text { Green glacial mud and sand; of bose of } \\
\text { Antarctic Continent slope; obout } 42 \\
\text { in. long. }\end{array}$ \\
\hline NEL 397 & 11 Mar & $3930^{\circ}$ & $14410^{\prime}$ & 28 & Scoopfish & Coerse shell sand, Bass Stroit, Austrolio \\
\hline NEL 398 & 11 Mar & $3930^{\prime}$ & $144^{-14}$ & 30 & Sccopfish & Coarse shell send, Boss Stroit, Austrolio \\
\hline NEL 399 & 11 Mar & $39^{\circ} 20^{\prime}$ & $14500^{\circ}$ & 32 & Sceopfish & Coorse shell sond, Boss Stroit, Australio \\
\hline NEL $\triangle 00$ & 11 Mar & $3920^{\circ}$ & $145 \cdot 30^{\circ}$ & 30 & Scoopfish & Coorse shell sand, Boss Stroit, Austrolie \\
\hline
\end{tabular}


The first two core samples (NEL 394 and NEL 395), obtained from the top of deep oceanic ridges, are similar in that they both consist of diatomaceous globigerina ooze. Also a flood of $G$. pachyderma, a pelagic polar species, is present in both of the samples. A fresh granite chip found in NEL 395 from Kerguelen-Gaussberg Ridge suggests that this structure may be, in part, granitic; however, this cannot be definitely established because such chips might reach their present location by ice rafting in this part of the world. The finding of globigerina ooze in a zone previously considered to be covered by diatomaceous ooze may be due to the topographically high position at which the samples were taken. In this case, the light diatomaceous material would have been largely winnowed out by current action and then transported into the surrounding basins. This is in line with recent observations elsewhere which have shown that topographic highs on the sea floor, regardless of depth, are covered with coarse sediment. Bottom currents at great depths are generally considered to be weak but currents associated with eddies with vertical axes or with internal waves are probably strong enough to stir up the finer bottom material. Thus a mechanism probably exists that sweeps the finest sediment from topographic highs.

Core sample NEL 396 was obtained from a depth of 2000 fathoms at the base of the continental slope of Antarctica in the vicinity of the Shackleton Ice Shelf. It consists of green mud and sand, and the poor sorting suggests that here the deposition of material rafted by ice was important. The presence of two cleanly washed sand layers is noteworthy in that it shows that effective currents must have existed even at this great depth.

The four bottom samples, NEL 397, 398, 399, 400, (see table 11) were obtained with an underway sampler, the "scoopfish," in the shallow waters of Bass Strait, Australia. All of the samples are similar in that they consist of a coarse shell sand. The performance of this new device which permits underway sampling was entirely satisfactory. It was used on the bathythermograph winch at speeds up to approximately 8 knots. 
Core samples NEL 394 and 396 were subjected to bacteriological analyses by $D$. M. Updegraff of the Scripps Institution of Oceanography. Various selective media were inoculated with about $0.5 \mathrm{gram}$ of sediment. The bacteria present are listed in table 12. Since the samples had been stored for a long period in unsterile containers before analy$\mathrm{sis}$, it is not certain that the results represent the conditions in the original sediment. However, every effort was made to avoid contamination by aseptically sampling the center of the cores.

Table 12. Bacteriological analyses.

\begin{tabular}{|c|c|c|c|c|c|}
\hline CORE NUMBER = : & \multicolumn{2}{|c|}{394} & \multicolumn{3}{|c|}{396} \\
\hline Distance from surface of core (inches) & 3-7 & $14-19$ & $3-6$ & $21-24$ & 33-36 \\
\hline Methane-sxidizing bocterio & - & 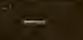 & - & - & - \\
\hline Acrobic heterotrephic bacteria & + & + & - & - & + \\
\hline Anocrobic hoterotrophic bacteria & $=$ & - & + & + & + \\
\hline Phenol-producing becteric (produce phenol from L-tyrosino) & - & - & - & - & - \\
\hline Aerobic hydrecerbon-ezidizing bocterio & + & - & - & + & + \\
\hline Anaerobic hydracarben-exidizing, sulfete-roducing becteria & - & - & - & $=$ & $=$ \\
\hline
\end{tabular}




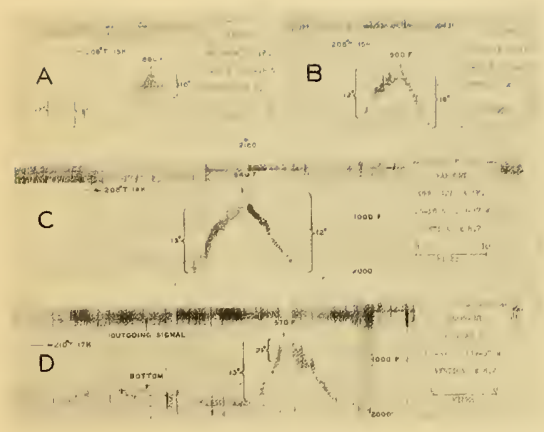

FIGURE 29. Fathometer bottom trace (fathagram) of four Pacific seamaunts.
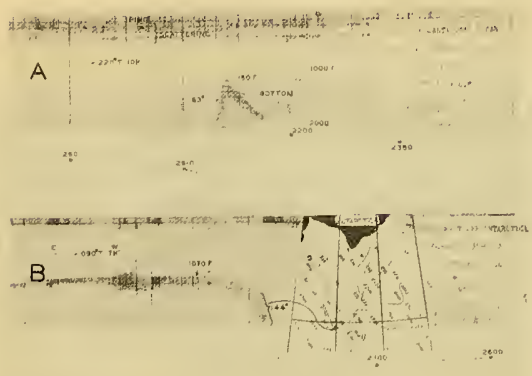

FIGURE 31. Fathograms af twa antarctic sea-floor escarpments.

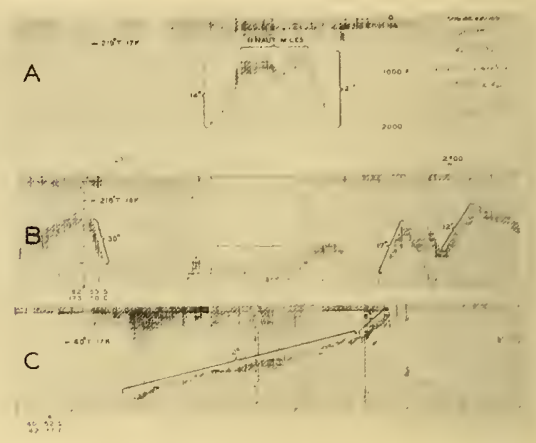

FIGURE 30. Fathograms showing a sauthwest Pacific seamount, the Eoster Island Swell, and the continental slope of south Australia.

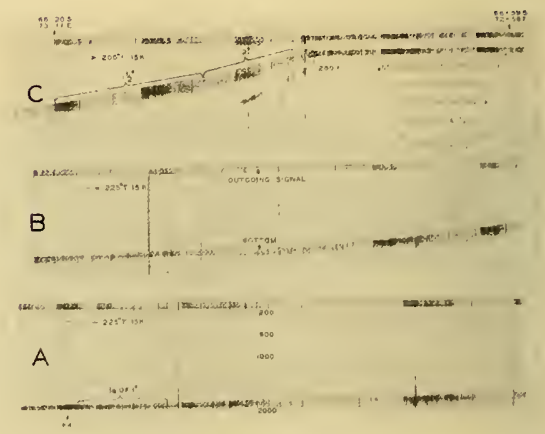

FIGURE 32. Fathogram of the cantinental slope of Antarctica near the Mackenzie Sea. 
General. During Operation HIGHJUMP the USS HENDER SON (DD785), under the command of Commander C. F. Bailey, made continuous soundings along her track with a model NMC Echo Sounder using 17-kc. sound pulses. Soundings less than 2000 fathoms were recorded automatically on a tape; soundings made at greater depths were obtained aurally every hour. Because almost all of the ocean bottom that was traversed is deeper than 2000 fathoms, a detailed recorded profile was obtained of only a few of the positive features such as tops of seamounts and escarpments. Features displayed on the HENDERSON fathogram that are of special geological interest have been reproduced and are discussed in this report.

Seamounts. A number of new seamounts were discovered during the San Diego-to-Antarctic passage. Four of the seamounts were found in the abyssal ocean off Baja California; an especially large one was discovered in the southwest Pacific off New Z ealand.

The two symmetrical seamounts shown in figure 29A were located about 300 miles southwest of Allaire Bank off Baja California. The larger seamount rises to a sharp peak at about 860 fathoms; the smaller one rises to a peak at 1400 fathoms. The sides of these seamounts are fairly steep, having a maximum average slope angle of 19 degrees.* Extension of the bottom echo when crossing the seamounts indicates steep slopes parallel to the ship's track and suggests that the vessel "sideswiped" the seamounts rather than passing directly over their highest peaks.

The seamount shown in figure $29 \mathrm{~B}$ was discovered off Baja California about 130 miles northwest of Allaire Bank. This one rises 1400 fathoms from the abyssal sea floor to a peak at 900 fathoms. The north side of this feature is irregular and concave and has a slope of $12^{\prime}$ degrees; the south side is straight and featureless and has a slope of 16 degrees. An examination of the pinnacle summit of the seamount reveals no evidence either of terracing or of truncation.

\footnotetext{
*In this report the apparent slope angles are corrected, assuming a 30-degree effective half-angle of the sound beam. ln other words, the sound beam is assumed to be semidirectional. However, the effective half-angle of the beam cannot be accurately determined since it varies with many factors such as gain setting and the roll of the ship. This correction is significant only for slopes greater than 15 degrees and the true slope is always greater than the corrected slope. The corrected slope is obtained by correcting the fathometertape slope for vertical exaggeration.
} 
The seamount shown in figure $29 \mathrm{C}$ rises to a sharp peak at 540 fathoms. This symmetrical feature was discovered 220 miles west of Alijos Rocks off Baja California. Its slightly irregular and upwardly concave sides have an average slope angle of about 12 degrees. The terrace which is present on the north slope at about 800 fathoms may be the result of wave e rosion, but this is very questionable. Echo extension suggests that this terrace is of rather limited horizontal extent normal to the recorded profile.

The largest seamount of all was discovered in the southwest Pacific about 1000 miles west of $\mathrm{New} Z \mathrm{Z}$ ealand in a sparsely sounded region (see fig. 30A). This feature rises from a sea floor depth of 2700 fathoms to a minimum depth of 600 fathoms. The extensive summit area is irregular and there is little evidence of wave truncation. The north slope has a declivity of 14 degrees as compared with 21 degrees for the south slope. Both slopes are slightly concave.

Another seamount (fig. 29D) was crossed near Hiva $\mathrm{Oa}$ in the Marquesas Islands. The presence of this seamount is suggested by soundings on published charts. It is reproduced here because it is located in a region where volcanic sediments have been found and because it is associated with the Marquesas Islands Atolls which are believed to be built on the summits of submarine volcanoes. For both of these reasons, it is quite certain that this feature is an extinct submarine volcano; therefore this seamount is useful for establishing criteria by which submarine volcanoes can be identified from their profiles. Especially noteworthy is the concave form of the flanks. The steeper northern side has an average declivity of 13 degrees with a maximum slope of 21 degrees near the summit. The somewhat gentler south flank is marked by a series of pinnacles. A plateau extends to the north of the seamount.

All of the seamounts that were observed have an appearance which suggests that they are of volcanic origin. Such an origin is suggested by their simplicity and symmetry of form, by their slightly concave slopes, and by the average angle of slope in excess of 10 degrees and not exceeding 21 degrees. In addition, the seamounts off Baja California are located at no great distance from the volcanic Guadalupe Island and in a region of known volcanicity. Yet it is possible that the seamount shown in figure $29 \mathrm{~B}$ is a south-facing fault escarpment rather than a volcanic mass. The slight asymmetry and the straightness of the south slope suggests this alternate interpretation. 
With the exception of the doubtful terrace at 800 fathoms on the seamount in figure $29 \mathrm{C}$, there is no good evidence of terracing or summit truncation of a type that would have resulted from wave planation if any of the seamounts had been near sea level at some time in its past history. This is in contrast to the discovery made by Hess ${ }^{7}$ that most seamounts in the west central Pacific show summit truncation.

Easter Island Swell. Existing charts, such as H.O. 2562, show that the Easter Is land $S$ well extends between Easter Island and the Antarctic Continent for a distance of several thousand miles. This swell, which is obviously a system of submarine mountain ranges comparable to some of the large cordilleras on continents must be the combined results of folding, faulting, and volcanism. Aural soundings that vere obtained prior to passing over the swell revealed a flat bottom, with no indication whatsoever of a foredeep. The profile of the northernmost portion of the swell (fig. $30 \mathrm{~B}$ ), shows a general absence of concave slopes. The presence of straight and slightly convex slopes suggests both faulting and folding. The southern flank of the northernmost mountain is so steep ( 30 degrees) that it is probably a fault scarp. There is no good evidence of summit truncation by wave erosion.

Escarpments. A most remarkable escarpment (fig. 31A) was discovered in the Antarctic Ocean about 80 miles north of the Easter Island Swell. Aural soundings that were obtained prior to crossing the escarpment revealed a foredeep at its base. This north-facing escarpment has the appearance of a tilted fault block. It rises from a depth of about 3000 fathoms to a sharp peak at 1180 fathoms, thus making a total relief of about two miles. The fault face has a straight profile and a declivity of 63 degrees. This is a minimum since, in calculating the slope, it was assumed that the ship traversed the escarpment at right angles. The dip slope is straight and has a slope of 11 degrees. The steepness of the escarpment, the asymmetry of the feature, and the presence of a foredeep clearly indicate that this feature was produced by high-angle faulting of large magnitude. The absence of effective erosive processes deep beneath the ocean has permitted the preservation of this fault block with "textbook-like" simplicity. The precipitousness of the escarpment probably exceeds that of any continental escarpment of comparable relief. For example, the angle of slope of the east face of the Sierra Nevada fault block averages only about 18 degrees. 
A second escarpment of considerable magnitude was located during two crossings of a submarine "spur" extending out 300 miles from the Antarctic Continent adjacent to Princess Ragnhild Coast. A profile of this escarpment, obtained during the west-to-east crossing, shows the probable faulted nature of the eastward side of the "spur" (see fig. 31B). The escarpment, with a 44-degree declivity, drops from 1100 fathoms to at least 2700 fathoms; and aural soundings suggest the presence of a foredeep. This escarpment is almost certainly the result either of faulting or of a sharp flexure in the earth's crust. It may have been produced by uplift of the elevated side, or by foundering of the deep portion or, most likely, by a horizontal movement along a fault which displaced a portion of the Antarctic Continent and formed the submarine "spur." This feature reminds one of the Gordo Escarpment off northern California which, according to Shepard, 8 may have been formed by horizontal displacement of the continental shelf along an extension of the San Andreas fault.

Continental Slopes and Submarine Canyons. During her passage a round the Indian Ocean sector of the Antarctic Continent, the HENDERSON remained for the most part in the deep water ( $g$ reater than 2000 fathoms) of the basins surrounding the continent. These basins are extremely level and no seamounts were found in them. At times the vessel ran along the continental slope where depths were less than 2000 fathoms so that the bottom was recorded on the echosounder tape. Irregular fathograms were obtained, but the presence of submarine canyons or of other indentations in the continental slope could not be definitely determined because of the constant maneuvering around the ice. There is no detailed record of the changes in the course during this maneuvering, thus many traces which appear to show indentation in the slope may have been produced by the changes in course along a smooth slope. The only conclusion that can be drawn is that no unquestionable examples of submarine canyons were found.

The HENDERSON reached the continental shelf of Antarctica only once. On this occasion, an excellent profile was recorded almost directly up the continental slope from the Indian Ocean to the Mackenzie Sea (fig. 32). In comparison with the slopes around other continents of the world, this one displays a profile that is remarkably long, smooth, and gentle. The slope has a long, sweeping, and concave form and in declivity it varies from two degrees near the top to about 
one-fourth of one degree at the bottom. There, 150 miles out from the continental shelf, the slope fades into the abysal sea floor. The gentleness and the concavity of the slope indicate that the present form of the profile is the result of extensive sedimentation of detritus carried across the shelf. However, this does not necessarily indicate that this continental slope is entirely built of a bank of sediments because extensive sedimentation might have modified an originally much steeper shape related to faulting or other causes. Examination of chart H.O. 2562 shows that this slope is somewhat gentler than a typical profile; however the antarctic continental slope appears to have a generally low gradient, indicating great deposition and probably attesting to the tremendous corrasive action of the continental glacier.

The top of the slope is marked by a sharp break-in slope at 280 fathoms, shoreward of which is a deep but level continental shelf. Also, seven crossings made by the CURRITUCK onto the antarctic continental shelf revealed marginal breakin slopes from 230 to 280 fathoms. This deep break-in slope at the shelf margin is in marked contrast to nonglaciated shelves in other parts of the world which generally have a break-in slope at about 72 fathoms. After traversing about 80 miles of level and featureless shelf about 250 fathoms in depth, the ship again passed over a sharp break-in slope at 280 fathoms. An oblique traverse down the slope to the southwest revealed a continental slope similar to that shown in figure 32 and indicated the absence of submarine canyors or other furrows cut into the slope in this region.

A second continental slope profile was obtained when the HENDERSON ran up the continental slope of south Australia from the South Australian Basin into Bass Strait between Australia and Tasmania (see fig. 30C). This lower portion of the slope is irregular and hummocky, with an abrupt change in slope at 550 fathoms. The lower portion of the slope has a declivity of about two degrees; the top portion has a declivity of six degrees. The break-in slope between the continental slope and the shelf occurs at about 80 fathoms. Judging from published charts, this slope is of normal declivity and form. However, the change in slope at 550 fathoms is interesting. One possible explanation for this break might be that detritus transported across the shelf moved down the steep six-degree slope and built up a wedge of sediment at the gentler angle of repose of two degrees. The hummocky form of this deeper slope might be attributed to landslides or to other mass movements. 


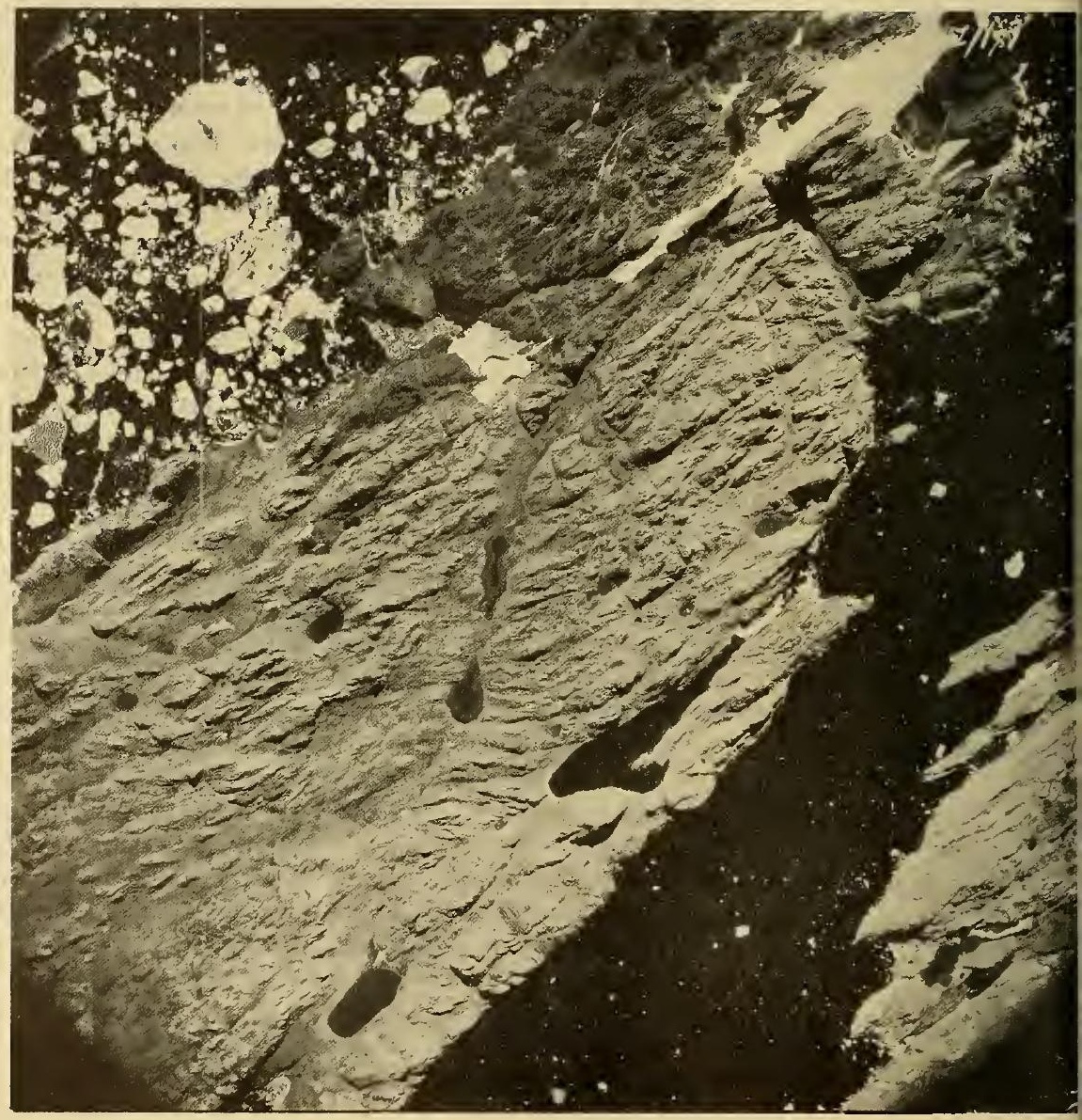

FIGURE 33. Verticol air photo showing a portion of Bungar's Oasis, a newly discovered ice-free areo in Antarctica. Note th scoured oppeoronce of the terroin, indicoting recent coverage by moving ice. 
Aircraft from the USS CURRITUCK photographed two extensive ice-free areas on the Indian Ocean sector of Antarctica. These "oases" are unusual because nearly all of the other known ice-free antarctic areas are nunataks (i.e., mountain peaks projecting through the polar ice plateau). An expedition was organized to fly into the first discovered area (Bungar's Oasis) to make a scientific reconnaisance, but unfavorable weather and lack of time prevented execution of this plan. However, some information about this area was obtained from aerial photos and from the sample of lake water obtained by the crew of Commander Bungar's aircraft.

Bungar's "Oasis" (approximate latitude 660 $15^{\prime}$ 's and longitude $100^{\circ} 15^{\prime} \mathrm{W}$ ) is a physiographically youthful region with rugged topography and nonintegrated drainage (see figs. 33 and 34). It is completely enclosed by an ice plateau which, in a few localities, tends to spill into the oasis. Judging from the flow lines, along the south and east boundary there are rapidly flowing streams of ice; along the west boundary there is a slowly moving, or possibly a stagnant, mass of ice; and along the north or coastal boundary there is a mass of relatively stagnant ice. Although the terrain is rugged, the hills, with an elevation of only a few hundred feet, rise to a concordant summit level which has the appearance of an old peneplain surface.

Scour lines indicate that, in the recent geological past, the oasis must have been overridden by ice that moved first in one direction and later in another. The area is covered with glacial rubble, and moraines and glacial erratics are present everywhere. However, the effect of the moving ice in this region has been mainly erosional. The ice has rounded the hills and produced roches moutonnees; it has grooved the terrain and gouged out the basins that are now occupied by lakes. The present physiography of the area is obviously largely the result of intense glaciation of massive rock.

The bed rock is well exposed, but it is difficult to determine the nature of the rock from aerial photographs. In the color photos examined, the reddish brown rock appears to be of a massive metamorphic type. The complexly contorted nature of the rock suggestive of metamorphism can be seen in figure 33. Two large black basic dikes that intrude the country rock are clearly discernible in figure 34. As there is no evidence of recent volcanism or thermal activity, the re is little basis for the widely publicized speculation that this area is heated by hot springs. The rocks of Bungar's Oas is are probably a portion of a vast shield of the pre-Cambrian(?) rocks that apparently forms the Indian Ocean sector of Antarctica. 
Bungar's Oasis is a land of lakes, many of which are entirely ice-free, whereas others contain brash ice and growlers. Some of the lakes occupy glacial gouge basins or are impounded by moraine or ice dams, forming a poorly integrated system. Water from some of the ice-impounded lakes must escape to the coast either through crevasses or through subglacial tunnels. The lakes are deep blue in color except where discolored by inflow of muddy water from fast flowing streams. The blue color suggests a relative paucity of organic matter in the lakes, but simple organisms such as algae are undoubtedly present. The aircraft crew reported that the water in the lakes felt several degrees above freezing; however it is doubtful if thermal springs have played any part in heating the water. The lakes are presumably fed by glacial melt waters by the melting of snow banks accumulated during the winter and by precipitation.

The sample of brackish water collected from one of the larger lakes, reported to be at an elevation of 200 feet according to the aircraft altimeter, was analyzed by N.M. Rakestraw. The chlorinity of the sample is $12.01 \% / 00$ (salinity $21.71 \mathrm{o} / \mathrm{oo}$, if sea water), which is a little more than half that of sea water. The $\mathrm{Ca}: \mathrm{Cl}$ is $0.0217(0.0215$ is the average $\mathrm{Ca}: \mathrm{Cl}$ of sea water). The $\mathrm{SO}_{4}: \mathrm{Cl}$ is $0.140(0.140$ is the average $\mathrm{SO}_{4}: \mathrm{Cl}$ of sea water). This analysis indicates that the water in this particular lake is composed of sea water diluted with rather pure fresh water.

The discovery that this reported brackish lake wate $r$ is diluted sea water is reasonable, because it would be difficult to understand how a saline lake could form in this region where the inflow of the water to the lakes must certainly exceed its evaporation. The reported lake elevation of 200 feet is probably in error because there was a difference in atmospheric pressure of about minus 0.2 inches of mercury between the point of take-off and the lake; this would make the actual situation of the lake little, if any, above sea level. The lake must be impounded by an ice dam, and the actual coast line (i.e., the zero contour line) must lie close to the oasis. The aircraft crew estimated the shoreline to be 10 or more miles away, but this shoreline is the contact of barrier ice with the open sea. The fact that the salinity of the water is less than 25 parts per thousand is of interest since such water will reach its greatest density above its freezing point and in winter, like a freshwater lake rather than like the ocean, it will freeze only at the surface. A reservoir of water of above-freezing temperature will remain beneath the ice during the winter and will speed up the thawing process with the coming of summer. 
This extensive ice-free area may have been formed by the diversion of plateau ice, because of surrounding rugged terrain, so that only stagnant ice remained over Bungar's Oasis. It is unlikely that thermally heated waters have played any part in producing the oasis. Presumably, meteorological conditions have been mild and the heat intake has been sufficient to waste away stagnant ice, thus producing an ice-free area when there was no replenishment of polar ice. Low precipitation, catabatic winds, close proximity to the ocean, and dark country rock with low albedo probably now contribute to maintain warmth in the area. The freezing of the lakes only at the surface and the heating of the water during the summer and then the sinking of this heated water into the lake must provide an additional heat reservoir. That the long summer day is sufficiently warm to melt banks of snow and ice deposited during the previous winter is suggested by the reported air temperature of 36 degrees $F$. when the aircraft landed. Also, the presence of many small lakes in the depressions of the surrounding plateau ice is indicative of extensive melting in this region. It is likely that the entire Indian Ocean coastal sector of the Antarctic Continent would be largely ice-free if it were not for the constant replenishment of ice from the polar plateau.

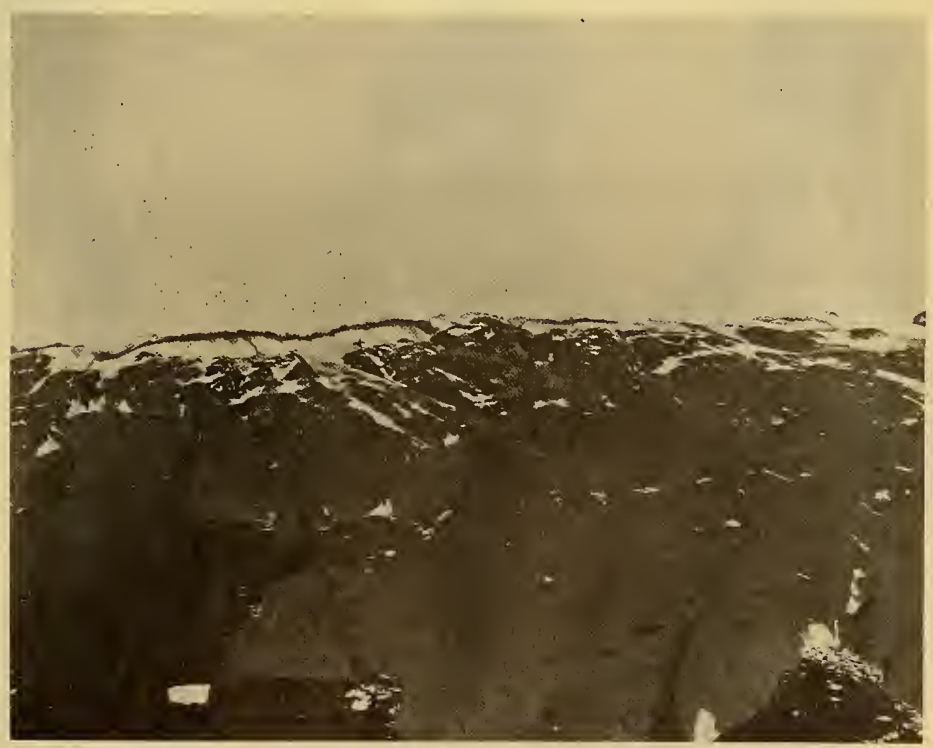

FIGURE 34. Oblique air photo of Bungar's Oasis showing contact of ice-free area with the surraunding ice plateav. Note the two large black dikes traversing the country rock. 


$$
i \bar{c}
$$




\title{
biological observations
}

\author{
BIOTA
}

General. As no qualified biologist accompanied vessels of the Western Task Group on Operation HIGHJUMP, only a few general biological observations worthy of recording here were made. Observations were limited to gaining a general impression of the biota and to obtaining some plankton net hauls. However, detailed observations were made on natural slicks and on the deep scattering layer, both of which are, in a sense, presumably biological phenomena.

Fish, birds, and mammals. Although fish, especially shallow-water bottom types of the genus, Notothenia, are reported to be present in antarctic waters, they were strikingly absent from view in the water traversed by ships of the Western Task Group. In addition to the fact that the NEL observers sighted no fish themselves, no fish were reported as being sighted by any of the personnel of the three vessels. A number of persons attempted to catch fish by the conventional hook-and-line methods, but these attempts failed. Also, birds were not seen feeding on bait; such an occurrence would certainly have been noted, had schools of small fish been commonly present.

Pelagic birds were extremely abundant south of the Antarctic Convergence, especially in the vicinity of the ice pack. However, from ships of the Western Task Group, no new observations were made concerning them.

Penguins were occasionally sighted on ice floes and were frequently seen swimming in the open sea many miles distant from the nearest ice. Figure 35 shows three Adelie penguins that were taken from an ice floe by personnel of the USS CURRITUCK.

Whales were numerous in the antarctic waters; usually a number were sighted during each watch. The seals that were sighted in the vicinity of the ice pack were usually resting upon the ice. Figure 36 shows one of the two seals that were captured from an ice floe by personnel of the USS CURRITUCK. 
Zooplankton. Vertical hauls to collect zooplankton were made by lowering a 25-centimeter silk plankton net to depths as great as 200 meters and then hauling it back to the surface. In this manner, 39 hauls were made from the USS HENDERSON en route to and while in the antarctic; 19 hauls were made from the USS CACOPAN. Also, numerous portions of bucket samples of surface water and portions of the Nansen bottle samples from various depths were preserved, primarily for quantitative phytoplankton studies. The samples, which were preserved in 4 per cent formalin, have been turned over to the Scripps Institution of Oceanography, University of California, for study and inclusion in their permanent biological collections.

No information is as yet available concerning the zooplankton collected in the net hauls during Operation HIGHJUMP. However, one interesting observation that was made from aboard the USS CURRITUCK is justifiably recorded here. In the vicinity of the ice pack (latitude $640 \mathrm{~S}$, longitude $130^{\circ} \mathrm{E}$ ), personnel aboard the USS CURRITUCK reported that an area of water, many acres in extent, was colored red by a swarm of shrimp-like organisms about one inch in length. Such a swarming of krill was not observed elsewhere.

Bioluminescence. Bioluminescence (so-called phosphorescence) was noted almost continuously at night in both tropical and subtropical waters but it was never strongly developed. The brightest display was observed on the night of 13 December 1946 in the tropical Pacific (latitude $22^{\circ} \mathrm{S}$, longitude $149^{\circ} \mathrm{W}$ ). Not once was bioluminescence observed in the antarctic, although frequent attempts were made to observe the phenomenon during the latter part of the antarctic summer when there were a considerable number of hours of total darkness. 


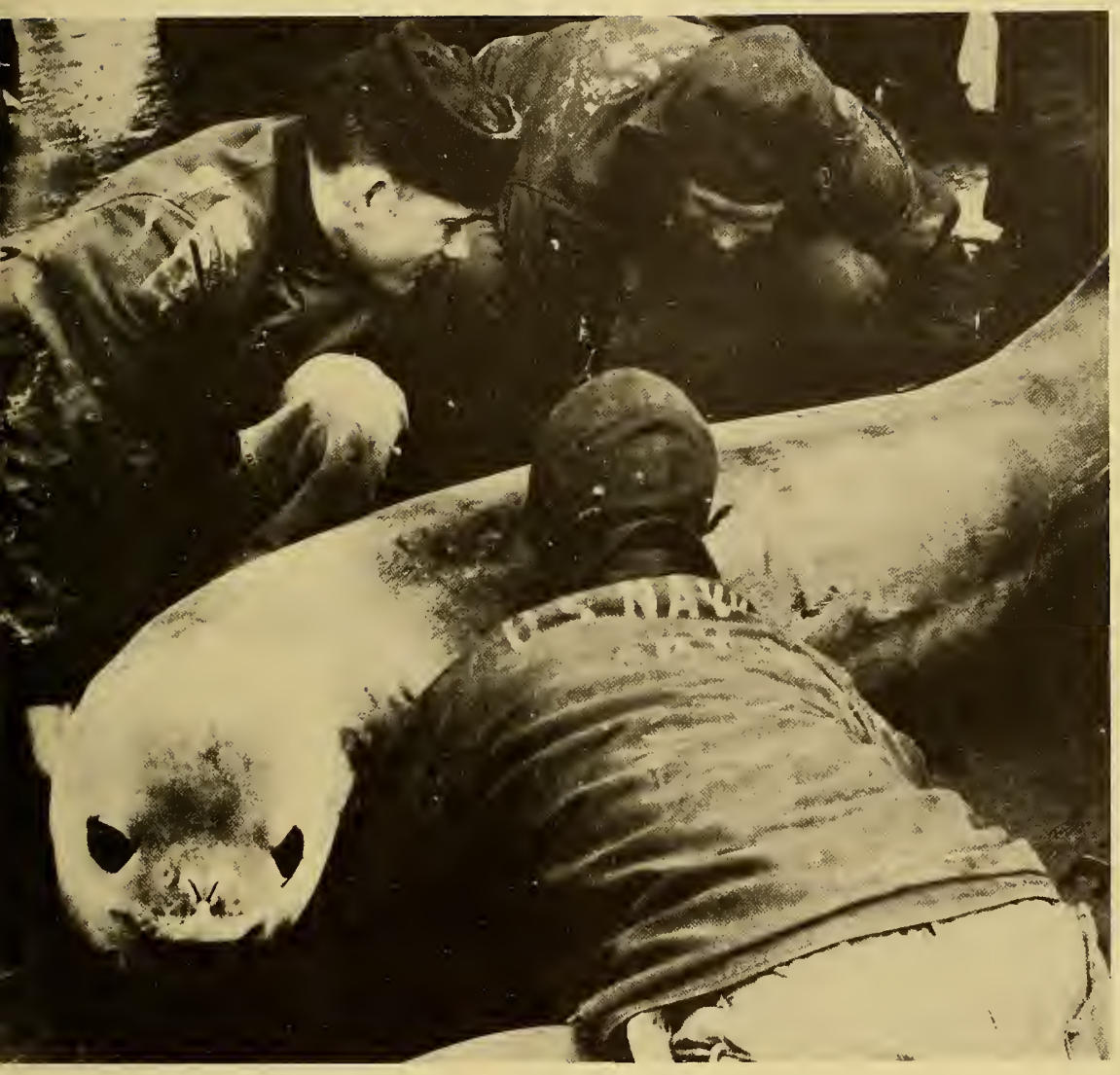

FIGURE 36. Seal captured fram an ice flae by men of the USS CURRITUCK. 


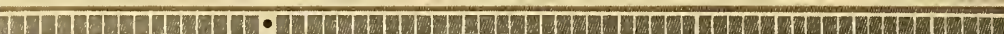

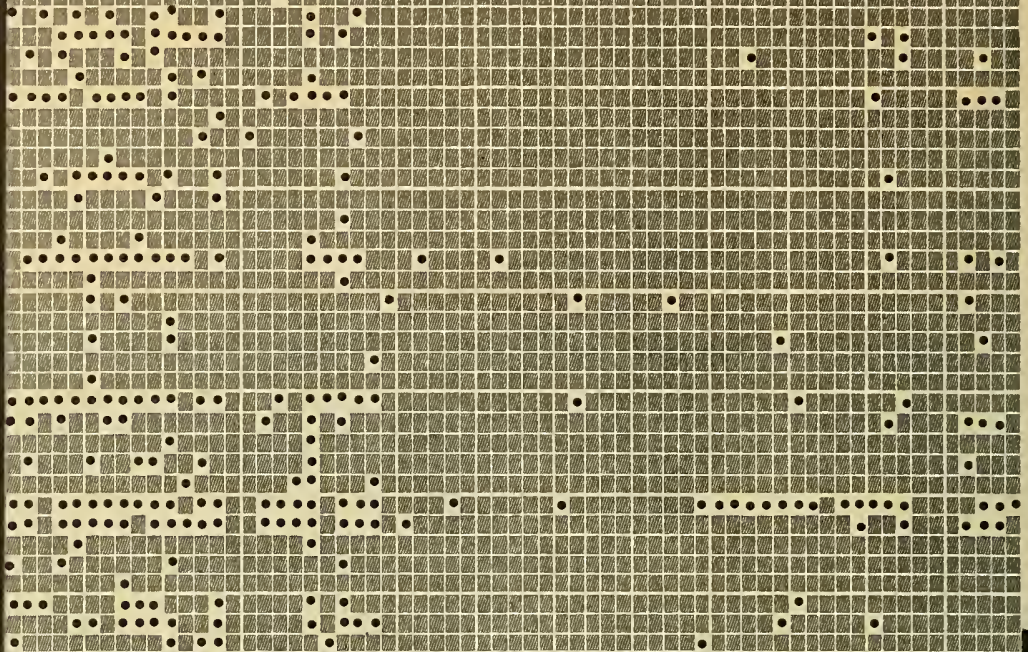
Drive Nam 5 -

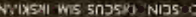

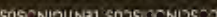

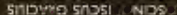

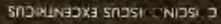

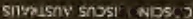
¿SINNDNCS SnOS1: NIOS: a S SnOSH: NIJSOS 25 SIONIS WMIIHECIYJ N'

SNEX-1E THL JMYTO

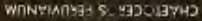

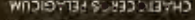

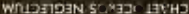

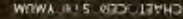
VIavolas 5 Pas 19:H

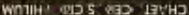

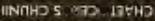

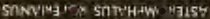
SnInAver: SnTMH:W Y7159 S1DV163H SITVH W- Y315:

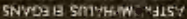

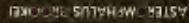
Whycint SRNAT SMTDNOCNIIOY

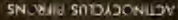

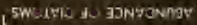

3105 งพu ros

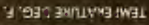

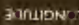
(5) Bsnuty
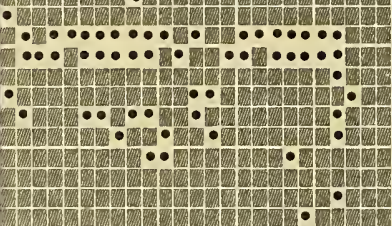

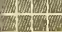

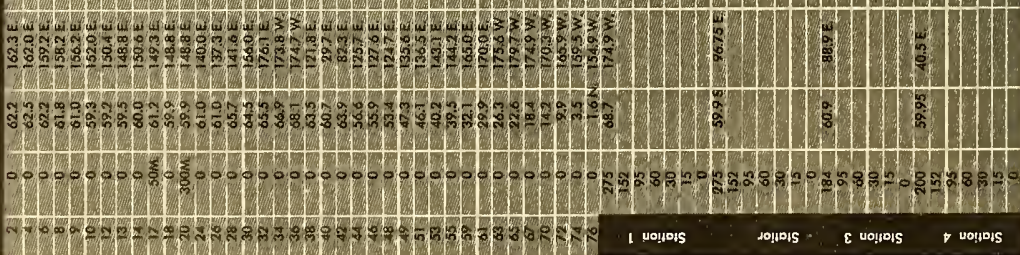

FIGURE 37. Chart showing marine planktan diatoms identified from water samples collected during Operatian HIGHJUMP. 
General. A series of water samples was collected from the USS CACOPAN on Operation HIGHJUMP for investigation of the Diatomaceae. The samples were collected by filling a citrate bottle either with surface water obtained with a bucket or with water obtained from various depths with Nansen bottles. The positions of those samples collected in the antarctic are plotted on figure 3 . The species of diatoms found at each station are listed in figure 37 with notations indicating the relative abundance of diatoms at each station.

According to the hydrographical data available, the Antarctic Convergence is not sharply defined in the area from which most of the diatom samples were taken, but lies somewhere between latitudes $59^{\circ} \mathrm{S}$ and $63^{\circ} \mathrm{S}$. Sample 42 , therefore, was taken from the polar waters south of the convergence and sample 44 was taken north of the convergence. There is a surface water temperature difference of about 10 degrees $F$. between the two stations, which is a further indication that the convergence has been crossed. It can be seen from table 8 that the antarctic circumpolar surface water south of the convergence supports an extremely rich phytoplankton population which is strikingly absent from the waters to the north of the convergence. The phytoplankton wealth of the antarctic waters has been frequently commented upon before. 9,10 Hart 10 has suggested that the diminished population in the subtropical and tropical regions are a result of the almost complete lack of nutrient salts in the surface waters of these regions, while in the polar regions nutrients cannot be regarded as a limiting factor at any time, since the content never falls below a minimum of about 0.9 mygram-atoms of $\mathrm{PO}_{4}$ per liter which is well above diatom needs. Hart considers that the high nutrient content is caused by the fact that the supply released by the spring break-up of the icepack is never exhausted. The marked vertical mixing of the antarctic waters, caused by weak thermal stratification, results in the ascent of nutrient-rich deep water. This is undoubtedly another cause of this nutrient surplus.

*This section was prepared by Brian Boden of Scripps Institution of Oceanography. 
The four hydrographic stations occupied in the polar waters revealed that the diatom concentration is scanty at the extreme surface, increases at 50 and 100 feet and then decreases until at great depths no diatoms are detected at all. The maximum depth at which a Secchi disc was seen at these four stations is as follows: station 1, 90 feet; station 2, 55 feet; station 3, 41 feet; and station 4, 68 feet. From this it can be seen that the euphotic and disphotic zones in these latitudes are very shallow. Diatoms flourish best in somewhat subdued light; the refore there is a subsurface diatom maximum. Schimpe $\mathrm{r}^{11}$ found diatom maxima at 40 to 80 meters in the antarctic. Sverdrup, Johnson, and Fleming 4 consider that this can be explained only as caused by sinking since photosynthesis cannot occur below 50 meters in these latitudes. The Secchi disc information available, together with the diatom concentrations at the different levels, confirm these comments. The diatom subsurface maximum at these stations was almost certainly between 50 feet and the surface.

Bathythermograms from these four stations reveal a marked seasonal thermocline (there is no winter thermocline in the antarctic waters) with about a 7-degree F. drop in temperature at depths from 60 to 130 feet. The presence of this stratification shows that the surface waters there have already spent some time as such. A certain degree of vertical stability, as is indicated here, is necessary for maximum diatom production, otherwise many of the diatoms are carried down beyond the euphotic zone. Thus, although data on the actual nutrient content of the water are lacking, the high diatom population above the thermocline in the euphotic zone (in surface waters which are "aged") is a strong indication that the re are still sufficient nutrients for good phytoplankton production. On crossing the Antarctic Convergence to the north, a remarkable drop in phytoplankton population was noted. Because of the stability in this region (figs. 15 and 16), vertical circulation is virtually absent and thus the replenishment of nutrients is slow. The paucity of diatom cells here indicates that the vernal "bloom" is over, so surface water nutrients are depleted. The appearance of a summer form such as Rhizosolenia hebetata f. semispina, and the absence of the primitive resting stage Rhizosolenia hebetata, also shows that the population is a summer one. 
An examination of one bottom sediment sample (NEL 394) revealed the following forms: Fragilariopsis antarctica; Fragilariopsis antarctica f. bouvet; Thalassiothrix longissima var. antarctica; numerous Coscinodiscus spp.; Charcotia bifrons; and spines of Chaetoceros. These are all very robust, highly silicified forms and capable of passing unaltered through the digestion tracts of "grazers." This probably accounts for their presence in the bottom sediment.

Methods. The investigation was carried out on semipermanent strewn-plankton mounts. The diatoms were washed six times in distilled water. They were allowed to settle for 24 hours between washings and the supernatant water was drawn off by means of a fine pipette and a vacuum pump. After the final washing a few drops of the sediment were placed on a slide and gently warmed until dry; a permanent mount was then prepared. For a critical examination of the species, a mountant with a high refractive index is necessary. For this purpose Hyrax (a synthetic resin with a refractive index of 1.71 ) was used. These preparations give excellent results and last for many months.

List of Species. The following is a list of the species encountered. They are arranged in alphabetical order to facilitate reference and the authority is quoted:

Actinocyclus bifrons, Karsten, 11 1905, p. 92.

Previous ly reported as common around South Sandwich Island and South Georgia, this species occurred but rarely in this collection.

Actinocyclus janus, Karsten, 11 1905, p. 92.

Amphora peragallorum, van Heurck, ${ }^{12} 1909$, p. 7 .

Asteromphalus brokkei, Bailey, ${ }^{13} 1856$, p. 2.

Asteromphalus elegans, Greville, ${ }^{14}$ 1859, p. 161.

Asteromphalus heptactis (Brebisson), Ralfs ex Pritchard, 15 1861, p. 838 . 
Asteromphalus parvulus, Karsten, ${ }^{11} 1905$, p. 90.

Asteromphalus roperianus, Ralfs ex Pritchard, ${ }^{15}$ 1861, p. 838.

Chaetoceros chunii, Karsten, 11 1905, p. 117.

Chaetoceros criophilum, Castracane, 16 1886, p. 78.

This is a very characteristic antarctic form. According to Hendy, 9 it very often dominates the plankton, together with Corethron criophilum (q.v.), in the extreme south.

Chaetoceros dichaeta, Ehrenberg, 17 1844, p. 200.

Chaetoceros didymum, Ehrenberg, 18 1845, p. 75 .

Chaetoceros neglectum, Karsten, 11 1905, p. 119.

This characteristically antarctic form has formerly been reported in great numbers around the South $S$ hetlands, South Georgia, South Sandwich Group, the Weddel Sea, and Belling shausen Sea.

Chaetoceros pelagicum, Cleve, 19 1873, p. 11.

Chaetoceros peruvianum, Brightwell,20 1856, p. 107.

Charcotia bifrons (Castracane), M. Peragallo, 21 1921, p. 78. Corethron criophilum, Castracane, 16 1886, p. 85.

Hendy 9 is followed in regarding Corethron as a monotypic genus. His comments on the various phases of this species are very complete and cannot be added to here. The species was not separated into phases or forms in this report, but all the forms did occur in the collection, frequently together.

Coscinodiscus australis, Karsten, 11 1905, p. 79.

Coscinodiscus excentricus, Ehrenberg, 22 1840, p. 146.

Coscinodiscus gracilis, Karsten, 11 1905, p. 78.

This identification should be treated with suspicion. This form has not been reported heretofore from the Pacific.

Coscinodiscus lentiginosus, Janisch in Schmidt, 231878 , p. 58. The type locality of this form is the Antarctic Ocean. 
Coscinodiscus lineatus, Ehrenberg, 24 1839, p. 129.

Coscinodiscus minimus, Karsten, ${ }^{11} 1905$, p. 78.

Coscinodiscus simbirskianus, Grunow, 251884 , p. 81 .

Dactyliosolen antarcticus, Castracane, 161886, p. 75 .

According to Hendy, 1937, p. 323 , this species exhibits three phases -- "Antarcticus," "borealis," and "laevis." The epithet used above designates only the "antarcticus" phase. The other two forms were not encountered in the collection.

Eucampia balaustium, Castracane, 16 1886, p. 97.

This form appeared frequently in the plankton but never in great numbers. Its extreme variability has been noted before (Hendy, 91937 , p. 286 and J. Hart, personal comm.) and at times it is rather difficult to identify on this account.

Eucampia cornuta (Cleve), Grunow ex van Heurck, 26 1880-5, pl. 95 b, f. 5 .

Fragilariopsis antarctica (Castracane), Hustedt in Schmidt, 23 1913, pl. 299, fs. 9-14.

Fragilariops is antarctica f. bouvet, Karsten, 11 1905, p. 123. Hendy, ${ }^{9} 1937$, p. 332 , states that antarctica is probably oceanic and the "bouvet" phase is probably neritic. The two forms are frequently associated and, in the HIGHJUMP collection, they are usually found together.

Grammatophora marina (Lyngbye), Kutzing, 27 1844, p. 128.

Guinardia flaccida (Castracane), H. Peragallo, 28 1892, p. 107.

Navicula trompii Cleve var. major, Heiden and Kolbe,29 1928, p. 625 .

Nitzschia closterium (Ehrenberg), Wm. Smith, 30 1853, p. 42. Hendy 9 gives the apical axis of this form as "up to $80 \mu$. " Numerous, longer cells, in the neighborhood of $100 \mu$ in length, were encountered in the HIGHJUMP collection. These forms are easily confused with $\mathrm{N}$. longissima (Brebisson) Ralfs, in Pritchard, 151861, p. 783 . The length of N. longissima, according to Cupp, 311943 , p. 200 , is $125-25 \overline{0 \mu}$. 
Nitzschia seriata, Cleve, 321883, p. 478.

Pinnularia lanceolata, Heiden and Kolbe, 291928, p. 598.

Pleurosigma directum, Grunow, 331880 , p. 53.

Occurs seldom in the plankton.

Rhizosolenia alata, Brightwe 11,341858, p. 96.

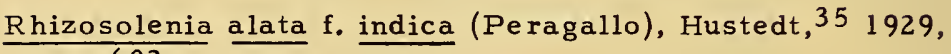
p. 602 .

Rhizosolenia alata f. inermis (Castracane), Hustedt, 35 1929, p. 602 .

Rhizosolenia antarctica, Karsten, 11 1905, p. 95.

Rhizosolenia bidens, Karsten, 11 1905, p. 98.

This form has markings similar to $R$. styliformis, but possesses a bifurcate spine. Heiden and Kolbe,291928, p. 517, have made it a form of $R$. styliformis. The diatom does not occur very frequently in the HIGHJUMP collection and the author has not been able to form any opinion as to its status.

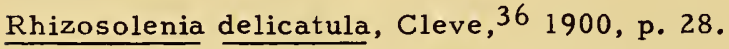

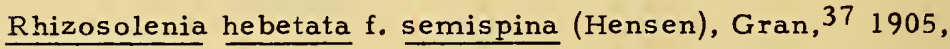
p. 55 .

A very variable form especially regarding size.

Rhizosolenia styliformis, Brightwell,34 1858, p. 95.

Rhizosolenia styliformis var. longispina, Hustedt in Schmidt, 23 1914, plate 316 , figs. $5-7,12$.

Schimperiella antarctica, Karsten, ${ }^{1} 1905$, p. 88.

The genus Schimperiella is confined to the Antarctica.

Synedra pelagica, Hendy, ${ }^{9} 1937$, p. 335.

This form is synonymous with $\underline{S}$. spathulata, Schimper ex Karsten, 11 1905, p. 124 but not $\underline{s}$. spathulata, O'Meara, 38 1875 , p. 310 . It is not uncommon in the plankton and often occurs with $\underline{\mathrm{S}}$. longissima. 
Thalassiosira antarctica, Comber, ${ }^{39} 1896$, p. 491.

This variable species is usually very common in antarctic waters but was comparatively rare in the HIGHJUMP collection.

Thalassiosira decipiens (Grunow ex van Heurck), Jorgensen, ${ }^{40}$ 1905, p. 96.

Reported formerly from the Pacific, as occurring in the Peru Current, by Hendy, ${ }^{9} 1937$, p. 239.

Thalassiotrix longissima (Cleve and Grunow) ${ }^{33}$ var. antarctica, (Schimper ex Karsten) Cleve and Moller.

The taxonomy of this form is extraordinarily confused. Hendy, ${ }^{1} 1937$, p. 335 refers to it as T. antarctica Karsten. Karsten, ${ }^{11}$ however, 1905 , p. 124, designates it T. antarctica Schimper, referring apparently to Schimper's Mss. notebook. Hendy, therefore, should have accorded the authority to Schimper ex Karsten. In a personal communication from Prof. Ruth Patrick, the form is referred to as $\mathrm{T}$. longissima var. antarctica, with the authority quoted as Cleve and Moller Type-slide No. 125. The author is constrained to agree with Prof. Patrick that this form does not warrant specific rank, but is merely a variety of $\mathrm{T}$. longissima. Although the author has been able to trace no published authority for this variety, he accords it to Cleve and Moller on the basis of Prof. Patrick's comments. This is one case where the Rules of Taxonomy should be suspended to obviate the ridiculous nomenclature given above.

The diatom is extremely common in the plankton and is frequently one of the dominant forms.

Tropidone is antarctica, (Grunow), Cleve, 41 1894, p. 24.

Tropidoneis glacialis var. constricta, Heiden and Kolbe, 29 1928 , p. 656. 
Natural slicks are glassy patches or streaks upon the surface of the ocean that give it a heterogeneous aspect insofar as the reflection of light is concerned. Prior to departure on Operation HIGHJUMP, it was decided to observe the distribution of these features. They have apparently received little previous attention, for there is little information about natural slicks in oceanographic literature.

It is known that the natural slicks are commonly referred to by fishermen and mariners as streaks where the wind is not striking the sea surface. Also, sailboats frequently avoid these areas of supposed calm. Yet, a few simple observations, such as watching the slicks drifting slowly with the current, show that the theory that they are produced by the wind is untenable. They are discussed in the biological section of this report in the belief that they are thin films of natural oil from organisms, especially diatoms; thus in a sense they are presumably a biological phenomenon. The fact that diatoms synthesize droplets of oil in their cells to provide a food reserve and also to assist them in keeping afloat is well known (Sverdrup, Johnson, and Fleming; ${ }^{4} \mathrm{Cupp}^{31}$ ). Upon their destruction, it is probable that these droplets of oil rise to the surface and that they then tend to spread into a monomolecular layer, thus producing slicks. Of course other marine animals may also contribute oil to form natural slicks but they are probably quantitatively unimportant as compared to diatoms. In any case, much of their oil results from grazing upon the diatoms.

If slicks are films of natural oils, one would expect them to be the most prominently developed in regions of high organic production, as in coastal waters and near islands where upwelling occurs. With this in mind, daily observations were made during Operation HIGHJUMP and such a distribution was found actually to exist.

Upon the departure of the ships from California on $2 \mathrm{De}-$ cember 1946, it was noted that slicks were developed rather prominently in the green coastal waters but that when the blue oceanic waters were reached the slicks had disappeared altogether. When the ships passed the Marquesas Islands, the only landfall en route to the antarctic, a slight development of slicks was noted. Although as a general rule slicks were not noted in oceanic water, on 15 December in the South Pacific (latitude $30048^{\prime} \mathrm{S}$, longitude $152^{\circ} 24^{\prime} \mathrm{W}$ ), with smooth sea conditions prevailing, some slicks were found that were just faintly discernible. 
Upon reaching the green antarctic waters, where organic production is notably high in the summer, prominent welldeveloped slicks were frequently observed, especially near the pack (fig. 38A). Aerial observers who were questioned reported generally good development of slicks in the antarctic coastal waters. Frequently slick-like areas were noted in the lee of melting ice. These areas appeared to have been caused by the spreading of fresh water over salt water (fig. 38B).

FIGURE 38 Top: Slick-like patches developed in the lee of melting brash ice. Such patches are often especially prominent in the lee of melting ice bergs. They are probably formed by relatively fresh water from the sea ice floating on sea water of greater density.
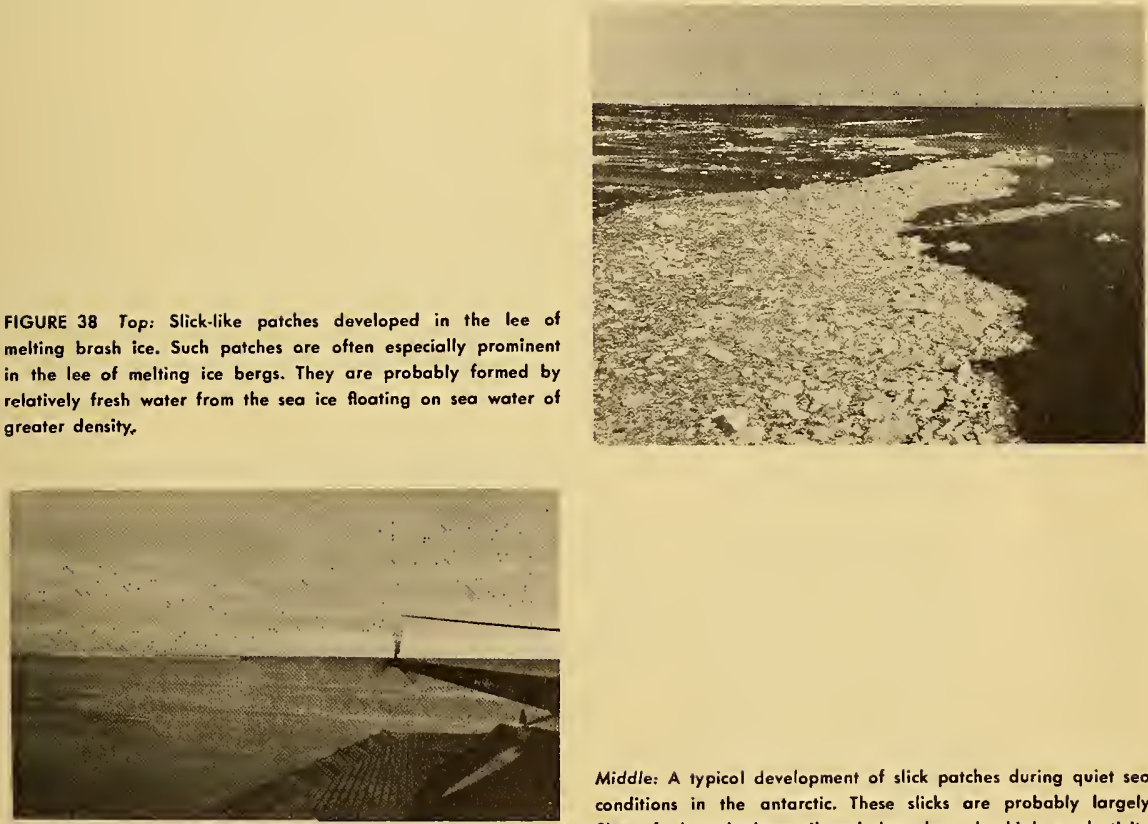

Middle: A typicol development of slick patches during quiet seo conditions in the antarctic. These slicks are probably largely films of phytoplankton oil and thus show the high productivity of these waters.

Bottom: Slicks in San Diego harbor probably resulting from both natural (diotom oil) sources ond artificial (ship's oil and refuse) 
Slicks were noted but once on the high seas during the homeward passage. These slicks, found in a subtropical area (latitude $20^{\circ} \mathrm{S}$, longitude $75^{\circ} \mathrm{W}$ ) under unusually calm conditions, were only faintly discernible. However, welldeveloped slicks were found in Australian coastal waters, and especially striking slicks were seen in the insular waters of American Samoa. And, when the coastal waters of California were reached, prominent slicks were again found.

Thus it would appear that, under favorable conditions, slicks that are just faintly discernible may be found in oceanic water, but that the most prominently developed slicks are to be found in coastal and insular waters that typically have high organic production. This further suggests that slicks are produced from natural oil of organisms and, conversely, that slicks may have a practical use as indicators of high organic productivity.

During Operation HIGHJUMP, it was noted that during calm conditions slicks have a patchy distribution but, under windy conditions, they drift with, or slightly faster than, the surface water and tend to line up in elongated streaks parallel to the wind. Probably the streaks are developed by the slick material collecting along small convergences associated with helical circulating cells of water in the homogeneous layer above the thermocline.42,43 High winds and attendant rough seas result in the complete disappearance of the slick patterns. A critical velocity of only a few miles per hour and no fetch at all is normally required to form capillary ripples, but a considerably higher wind velocity is needed to produce ripples in a slick area.

Slicks appear as glassy streaks largely because they damp out the small ripples and thus produce a calm area in the midst of rough water. This calming effect appears to be mainly caused by the molecules of the slick film forming a cohesive and nonmiscible blanket over the water so that the slick particles do not take part in the vertically circular motion described by the water molecules when ripples are present. In addition to the damping effect that slicks have upon the water ripples entering a slick patch, the slick substance itself probably resists the formation of capillary ripples because of certain physical properties such as a relatively high viscosity. Also, there must be a considerable frictional drag along the slick-water boundary, and the film is so thin that the vertical circulation necessary to produce capillary ripples with the slick substance cannot be set up. $T$ hus, even a fresh water film such as from melting ice floating on top of cold and saline salt water can produce a slick. But, the fact that slicks are generally surface films 
of a foreign substance has been demonstrated by the unpublished work of E. C. LaFond and of D. E. Root, both of whom have shown that the surface tension of water collected from slicks is less than that of other sea water. Also, surface bubbles produced on slicks tend to persist while those in other water disappear rapidly.

Artificial slicks produced by ship's oil and other refuse are present in harbors (fig. $38 \mathrm{C}$ ), where they frequently constitute a fire hazard. They have often been artificially produced on the high seas by ships in distress to damp the roughness of storm waves to keep them from breaking. Artificial slicks can be readily produced by almost any fluid which is nonmiscible and lighter than water. Fluids of low surface tension are especially good slick producers because of their rapid spreading ability. 44 Newly formed artificial slicks commonly display high-order interference colors whereas natural slicks display no color other than possibly a first-order gray, but this difference is obviously related to the relatively large thickness of the newly formed film of an artificial slick. In general, a similar type of origin for natural slicks and for artificial slicks is suggested by their similar appearance. Petroleum released from oil seeps on the sea floor may be responsible for some local slicks, but diatom oil must largely account for the widespread development of slicks in coastal and insular waters.

\section{DEEP SCATTERING LAYER IN THE PACIFIC AND ANTAKCTIC OCEANS*}

Introduction. During Operation HIGHJUMP (U.S. Navy Antarctic Development Project, 1947), the writer frequently noted the presence of a layer of deep scatterers on the fathogram of the USS HENDERSON. This layer partially scatters the outgoing sound signal of the recording echo sounder during daylight hours so that a reflection is recorded which shows a false bottom at various depths between 150 and 450 fathoms.

\footnotetext{
*The writer is indebted to C. Eckart and R. W. Raitt of the University of California Marine Physical Laboratory, to M. W. Johns on of the Scripps Institution of Oceanography, and to R. J. Christensen, E. C. LaFond, and D. W. Pritchard of the U.S. Navy Electronics Laboratory for critically reading this manuscript. The fathograms from which the data are taken we re obtained by the personnel of the USS HENDERSON and the USS NEREUS. In connection with obtaining the fathograms, the assistance of Captain C. F. Bailey of the USS HENDERSON and of E. C. LaFond, who supervised the obtaining of the arctic fathograms of the USS NEREUS, is especially appreciated.
} 
Subsequent examination of a fathogram across the Pacific and one from Hawaii to the arctic also revealed the frequent display of this phenomenon. As these records greatly increase the present knowledge of the geographic distribution and as other new information was observed regarding this phenomenon, the results of an examination of these three fathograms is presented in this paper.

Previous Investigations. Previous investigations 45-49 made with sonar gear since 1942 by workers at the University of California Division of War Research and later at the U.S. Navy Electronics Laboratory, the Scripps Institution of Oceanography, and the University of California Marine Physical Laboratory revealed that sound scatterers are not uniformly distributed in the ocean but that they exhibit a striking variation with depth. Frequently, at about 175 fathoms, an exceptionally well-defined layer of scatterers was found that had at least ten times the scattering power of scatterers at shoaler depths.

It was noted that this deep scattering layer* is principally a daytime phenomenon. In the morning, scatterers descended from near the surface to form the deep scattering layer and in the evening they ascended toward the surface. Such a diurnal cycle strongly suggested that this phenomenon was caused by migrating marine organisms rather than by a physical discontinuity in the water (e.g., a temperature change). Also, a temperature-change boundary could not account for the intensity of the scattered sound. It is well known from net hauls that offshore zooplankton in general (such as the copepods Calanus finmarchicus and Metridia lucens, pelagic prawns, euphausiids, and many others) exhibit negative phototropism and that they make daily vertical migrations from the surface to depths as great as 2500 feet. Presumably, many types of zooplankton migrate to the surface at night to feed in the phytoplankton-rich surface layers and in the morning they descend to regions of darkness at great depth,

\footnotetext{
*It has also been suggested that this layer of deep scatterers be called the ECR layer in recognition of the joint discovery by C. F. Eyring, R. J. Christensen, and R. W. Raitt, in connection with underwater sound work at the University of California Division of War Research. Other workers who have made important contributions to the study of this phenomenon include C. Eckart, G. E. Duvall, R. Ely, and M. W. Johnson. M. W. Johnson first showed the apparently biological nature of the scattering layer. Most of the studies by these workers are in anonymous wartime reports.
} 
possibly for safety from their predators. However, many marine zooplankton forms may be too small to scatter 18-kc. sound effectively. For this reason it has been suggested that the sound scatterers are nekton such as fish or squid which follow and feed upon the zooplankton. In any case it is probable that migrating zooplankton are at least indirectly responsible for the deep scattering layer.

There is comparatively little previous information regarding the geographical distribution of the deep scattering layer. It is known to be frequently present off the California and Baja California coasts, especially during the day. It has been occasionally reported from various spots in the Pacific. Fecently, workers at Woods Hole Oceanographic Institution have reported (personal communication) the presence of this phenomenon in the Atlantic Ocean. Also it is probable that some of the uncharted shoals reported by ships at sea are false bottoms ascribable to the deep scattering layer.

Deep Scattering Layer on the USS HENDERSON and USS NEREUS Fathograms. Prior to a discussion of the HENDERSON and NEREUS types, it should be pointed out that the absence of a record of the deep scattering layer on the fathogram does not necessarily preclude its presence, because such absence may be due to mistuning or to other causes. A low gain setting will fail to bring in the deep scattering layer; on the other hand, a gain setting which is too high may mask the layer. Such changes in sensitivity undoubtedly account for its alternate disappearance and reappearance throughout certain days. The layer may also be masked by background noise produced by the ship when underway or by operation of ship's equipment of various kinds. However when it does not show up throughout a long period of time, it may be assumed that it is absent or at least that it is very poorly developed. Throughout these cruises, the echo sounders were primarily operated to obtain depth information and the recording of the deep scattering layer was incidental. The length of the outgoing sound signal masked any echoes from the layer when it ascended to depths of less than about 100 fathoms on the HENDERSON record and less than about 60 fathoms on the NEREUS tape. The time used throughout this paper is the standard time for the zone in which the ship was located. The NMC fathometer of the HENDERSON and the NMC-1 fathometer of the NEREUS utilized 18-kc. sound pulses. 
The distribution of the deep scattering layer during Operation HIGHJUMP and other cruises is shown in figure 39; its general appearance is shown in figure 40 . With the exception of two days in the vicinity of the Marquesas Islands, the layer was recorded the greater part of each day during the daylight hours throughout the passage from San Diego to the antarctic from 2 December to 23 December 1946. Controlled by the length of daylight, the layer was detected at least discontinuously for as short as a 10-hour period and as long as a 19-hour period. Except in the early morning or in the late evening at times when the layer was actively migrating, it was developed at depths that ranged from 150 to 450 fathoms. Near San Diego a depth of about 150 to $200 \mathrm{fa}-$ thoms were characteristic whereas, in the tropical and southern waters, a depth of 200 to 350 fathoms was more typical. The ascent and the descent of the layer were closely correlated with sunset and sunrise. With the exception of one or two questionable sporadic displays of the deep scattering layer, it was completely absent from the fathogram during hours of darkness. The phenomenon of a double layer was frequently displayed.

The Antarctic Convergence was crossed at noon on $23 \mathrm{De}-$ cember in the vicinity of latitude $62^{\circ} \mathrm{S}$. This water-mass boundary was clearly indicated by the abrupt drop in temperature from 39 to 33 degrees $F$. It is noteworthy that the deep scattering layer disappeared completely for three days after the ship crossed this boundary and that it was seldom observed to be well-developed in antarctic waters.

During the period from 25 December to 2 March, the HENDERSON navigated slowly westward along the western Pacific and Indian Ocean sectors of Antarctica. Only a few indications of layers of deep scatterers were recorded for short intervals from 27 December to 21 January, a period of permanent or of almost permanent daylight. From 21 to 29 January, the deep scattering layer was again well-developed and during this interval displayed the typical diurnal cycle (fig. 40). This display might be correlated with the return of a day-and-night cycle because by this date there were a few hours of complete darkness. However, after 2 February, the deep scattering layer was seldom observed either during the remainder of the artarctic cruise or en route to Australia.

During the return passage from Australia to the United States, the deep scattering layer was detected on the third day out of Sidney. The typical diurnal cycle was recorded each day until the echo sounder went out of operation (at about latitude $20^{\circ} \mathrm{S}$ ) because of mechanical failure. 

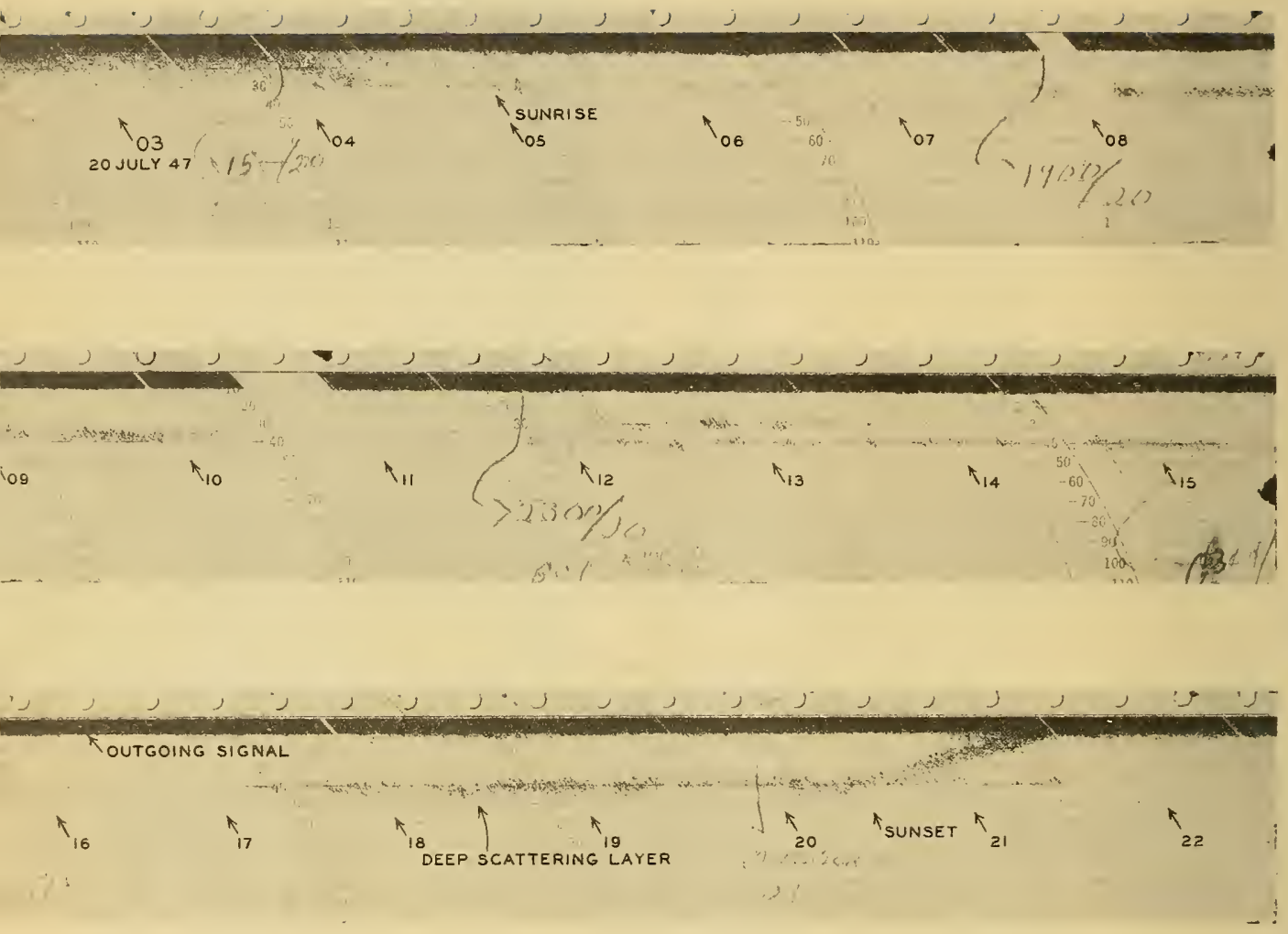

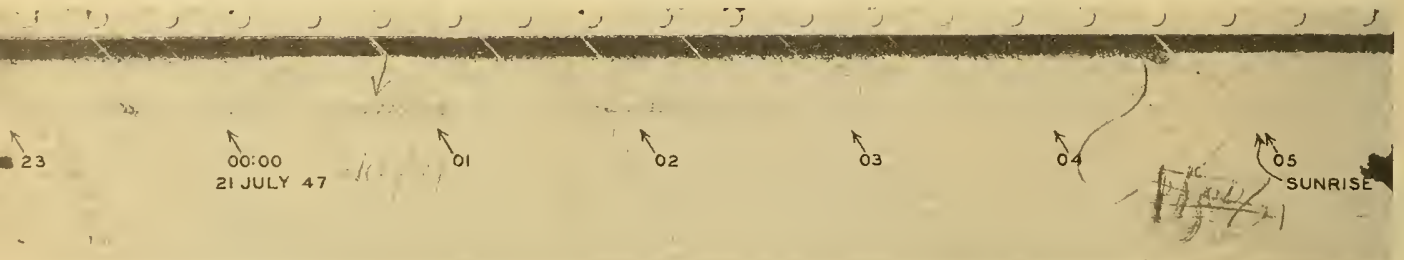

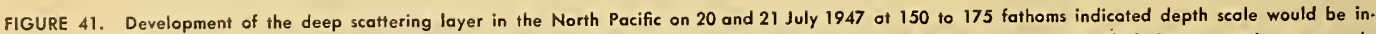

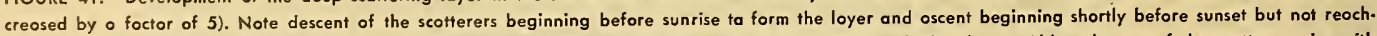

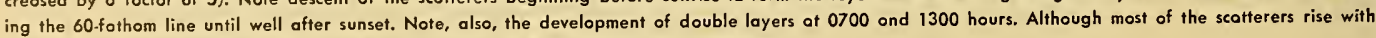
nightfoll, this fothogrom shows the unusual development of a layer throughout the night. 
During the period between 15 July and 10 August 1947, the USS NEREUS made a continuous fathogram from Pearl Harbor to the arctic with an NMC-1 fathometer using 18-kc. sound pulses. The itinerary was via Adak and the Bering Sea. This fathogram shows indications of the development of the deep scattering laye $\mathbf{r}$ each day throughout the cruise whenever the vessel was in deep oceanic water. The shoal depth of the Bering Sea precluded the development of a deep layer of scatterers and the fathogram shows no evidence of any layers of scatterers in these areas.

The NEREUS fathogram displays especially well the morning descent and the evening ascent of scatterers. They appear to migrate as a laye $r$ rather than diffused but the movement of scatterers in depths less than 60 fathoms cannot be determined because of masking by the qutgoing ping. Although the diurnal vertical migration is well displayed, the scatterers descended to a depth so great that, throughout most days, they were beyond the range of good detection by the echo sounder; therefore it was only sporadically recorded.

On 20 July at noon position of latitude $44^{\circ} 49^{\prime} \mathrm{N}$, longitude $175^{\circ} 19^{\prime} \mathrm{W}$, the layer was prominently developed throughout the entire day (fig. 41). This comparatively strong development of the layer may have been caused by a higher concentration of scattering organisms in the productive waters of the Aleutian (Subarctic) Current which lies between latitude $42^{\circ} \mathrm{N}$ and the Aleutian Islands. The development of the deep scattering layer from 175 to 225 fathoms was in agreement with depths observed elsewhere. Twice during this day, a double layer appeared. Especially surprising was that, although a portion of the scatterers rise at sunset, the rest remained at a depth of 175 fathoms throughout the night. A1though the other tapes examined occasionally show sporadic indications of a scattering layer at night, this was the only record of a prominent and continuous layer throughout the most of the night.

Another interesting phenomenon noted only on the NEREUS fathogram was the presence of a double layer descending each morning during the period from 15 July to 18 July. These double descending layers were separated by a time interval of about 20 minutes and apparently were the result of the downward migrations of two types of organisms that are negatively phototropic to markedly different degrees. Yet, at sunset of these same days, only a single ascending layer was noted. 
The vertical migrations were so clearly defined on the NEREUS tape that it was possible to measure roughly the rate of ascent and descent. In the morning the scatterers appear to descend at a rate of about 10 to 15 feet per minute. The evening ascent was slightly more rapid and was accomplished at a rate of about 15 to 18 feet per minute.

In agreement with all other observations, the deep scattering layer was almost entirely a daytime phenomenon and the vertical migrations were closely correlated with sunrise and sunset or, more exactly, with the beginning and end of a certain, but unknown, amount of twilight. The descent, deeper than 50 fathoms, began about one hour before sunrise and the layer attained its maximum depth shortly after sunrise. The layer varied only slightly from this depth throughout the day. The evening ascent began shortly before sunset but did not reach the 50-fathom depth until about one hour after sunset. Just what became of the layer at depth shoaler than 50 fathoms is not known because any further rise of the layer was masked by the outgoing signal. However, prominent extension of the outgoing signal during hours of darkness indicated the abundance of scatterers in the upper 50 fathoms of water.

During the period from 11 August to 1 September 1947, the USS HENDERSON obtained a fathogram across the Pacific Ocean with a recording NMC fathometer from San Diego, California, to Yokosuka, Japan, via Pearl Harbor, Hawaii. Although the fathometer was operating erratically most of the time so that the fathogram is poor, the deep scattering layer can be at least sporadically detected almost every day at various times during daylight hours. From the fathogram it appears probable that a properly working and sufficiently sensitive echo sounder would have recorded a daytime development of the deep scattering layer essentially continuously across the Pacific.

When the vertical migration of the layer was clearly recorded, it invariably began to descend about one-half hour or more before sunrise and to rise shortly before sunset; however the upward migration was not completed until after sunset. Multiple layers were occasionally present and the scatterers were located at a depth between 150 and $250 \mathrm{fa}-$ thoms.

During the first half of the San Diego to Pearl Harbor passage, the layer was present during portions of each day at a depth from 175 to 250 fathoms. Because of mechanical failure, the echo sounder was not in operation during the last half of this passage. 
After leaving Pearl Harbor, the layer was fairly welldeveloped the first day out of port. During the next two days, it was not detected. Yet from the fourth day out of port until arriving in the shallow water off Japan, five days later, the layer was recorded every day and it appeared to become more strongly developed with westward penetration.

Discussion and Conclusions. Examination of three fathograms, which cross the Pacific in both a North-South and an East-West direction and cover a sector of the Antarctic Ocean, shows a wide development of the deep scattering layer. It appears to be an oceanic phenomenon which is Pacific-wide and probably world-wide.

All of these records further substantiate the diurnal cycle by which the scatterers descend in the morning and ascend to near the surface at night. On the NEREUS fathogram, the scatterers begin their descent about one hour before sunrise and they do not complete their ascent until about one hour after sunset, so the scatterers are in the surface waters only during rather complete darkness. Apparently the scatterers are motivated by a small amount of light, so the migrations are actually correlated with a certain amount of twilight rather than sunrise and sunset. No information.was obtained on the distribution of scatterers in the surface water at night because of masking by the outgoing ping.

Because of the diurnal cycle, it is evident that the deep scattering layer is a biological phenomenon, so the scattering agents must be zooplankton, nekton, or bubbles associated with some organisms. Yet, from these records, no definite conclusion can be drawn as to whether zooplankton or fish cause the scattering. It will be necessary to make numerous laboratory experiments on the scattering characteristics of the various forms and to correlate underwater sound data with net hauls before the nature of the scatterers can be established. However, the extensive distribution of the deep scattering layer is suggestive of zooplankton. The comparatively slow speed and the migration of the scatterers as a layer is, perhaps, more suggestive of the general zooplankton than of faster swimming fish. The occasional development of night layers, of double descending layers, and of multiple deep layers of scatterers show that the phenomenon is complicated and probably involves many kinds of organisms and different stages of development of a single species.

The amount of scattering is dependent in part on the sum of the cross-sections of all of the objects present. The total 
mass of zooplankton in the ocean is many times the mass of fish. Also, since the mass of a body varies as the cube of any linear dimension, whereas the surface varies as the square, a given mass of small organism such as zooplankton present a much greater surface from which scattering might take place than an equal mass of fish. Thus the extensive and frequently continuous distribution of the deep scattering layer suggests that pelagic zooplankton may be the basic cause of the phenomenon. Yet, if zooplankton scatter sound like solid or liquid particles, most of them are too small to be effective scatterers of $18-\mathrm{kc}$. sound, which has a wave length of about 3 inches in water, because the scattering efficiency of an object smaller than the wave length is proportional to $(d / \lambda)^{4}$, where $\lambda$ is the wavelength of the sound signal, and $d$ is the circumfexence of the scattering object. Therefore, solid or liquid particles are inefficient scatterers if less than about one inch, so an unreasonably high concentration of such organisms is required to produce the observed scattering. Also the intensity of the scattering from small organisms is highly dependent upon the frequency of the sound but, in work off California, such frequency dependence has been shown not to exist. Thus, although the small zooplankton such as the copepods are probably not the scatterers, larger. forms such as the euphausiids, which often reach the length of about one inch, may possibly cause the scattering.

Very small air bubbles in water are known to be excellent scatterers of sound because a gas has a markedly different density and compressibility than water. For this reason, gas bubbles have an "effective diameter" for scattering sound of many times their actual physical diameter. Scattering is especially great if the bubble is af a certain critical size so that it is resonant. The diameter of a resonant air bubble in water for $18-\mathrm{kc}$. sound is about 1.5 millimeters at 150 fathoms, about 2.0 millimeters at 265 fathoms, and $2.5 \mathrm{milli}-$ meters at 415 fathoms. The size of a resonant gas bubble enclosed in a marine organism would vary somewhat from these figures because it would depend upon the elastic properties of the organism and the type of gas. In any event, if minute bubbles are enclosed in the migrating organisms or if they are excreted by these organisms and exist for a short interval before being dissolved, they would probably adequately account for the phenomenon of deep scattering. However there is no record of the presence of such bubbles in vertically migrating types of pelagic organisms.

As might be expected, there appears to be some correlation between the depth of the deep scattering layer and factors 
which control the depth penetration of light. For example previous observations 48 in coastal water off California showed the characteristic depth to be about 150 to 200 fathoms. A similar depth was observed off California on the HENDERSON records. However in the oceanic tropical and subtropical Pacific under conditions of highly transparent water and an overhead sun, the deep scattering layer was typically at a depth from 250 to 350 fathoms. No good correlation was detected between the amount of cloud cover and the depth of the layer.

An interesting question to consider is what effect the continuous daylight of polar midsummer has upon the diurnal cycle of the scatterers. From the HENDERSON fathogram it appears that the layer generally does not form under conditions of permanent or almost permanent daylight. Yet, weakly developed and questionable layers of deep scatterers were sporadically present. In this connection, net haul studies of plankton by Bogorov 50 are noteworthy. According to his studies, zooplankton in the Barents Sea (latitude $75^{\circ} \mathrm{N}$ ), under conditions of permanent daylight, do not perform the regular vertical migrations that are characteristic of zooplankton of lower latitudes but rather they maintain an almost unchanged vertical distribution throughout a 24-hour period. Further south in the White Sea (latitude 650S) Bogorov noted the presence of a mixture of both the usual migrating types and the polar nonmigrating types of zooplankton.

Correlated with the return of a day-night cycle in the antarctic toward the end of January, the diurnal migrating of the scatterers and the development of a deep scattering layer was once again detected. However, in this connection, the almost complete absence of the layer during both February and the first part of March is puzzling and without a reasonable explanation.

Investigation of the deep scattering layer is a fertile field for research. This phenomenon is of importance in connection with the transmission of underwater sound. If the scatterers are, even in part, fish, a study of the layer is of obvious direct commercial value. If the scatterers are zooplankton, much can be learned about these organisms, their habits, and distribution. Also, if measurements are made under controlled conditions so a scattering coefficient can be obtained, roughly quantitative data concerning the populations of the scatterers might be obtained. A study of the variation of the amount of scattering with sound pulses of various frequency would yield information on the size of the scatterers. 


\section{bibliography}

1. Deacon, G.E.R., "The Hydrology of the Southern Ocean," Discovery Reports, vol. 15, pp. 1-124, 1937.

2. Oxner, M., "Chloruration par la methods de Knudsen," Bulletin de la Commission Internationale pour l'Exploration Scientifique de la Mer Mediterranee, No. 3, 1920. (Translated by Deevy, G., "The Determination of Chlorinity by the Knudsen Method," Woods Hole Oceanographic Institution, Woods Hole, Mass., 1946.)

3. Knudsen, M., Hydrographical Tables, 1901.

4. Sverdrup, H.U., M.W. Johnson and R.H. Fleming, The Oceans: Their Physics, Chemistry, and General Biology, Prentice-Hall Inc., New York, 1942.

5. Byrd, R.E., "Exploring the Ice Age in Antarctica," National Geographic Magazine, vol. 68, No. 4, p. 430, 1935.

6. Emery, K.O. and R.S. Dietz, "Gravity Coring Instrument and Mechanics of Sediment Coring," Bulletin of Geological Society of America, vol. 53, pp. 1685-1714, 1941 .

7. Hess, H.H., "Drowned Ancient Islands of the Pacific Basin," American Journal of Science, vol. 244, pp. 772-791, 1946.

8. Shepard, F.P., "Submarine Topography off the California Coast," Geological Society of America, Special Papers, No. 31, pp. 35-41, 1941.

9. Hendy, N.I., "The Plankton Diatoms of the Southern Seas," Discovery Reports, vol. 16, pp. 151-364, 1937. 
10. Hart, T.J., "On the Phytoplankton of the Southwest Atlantic and the Bellingshausen Sea," Discovery Reports, vol. 8 , pp. $1-268,1934$.

11. Karsten, G., "Das Phytoplankton des Anarktischen Meeres nach dem Material der Deutschen Tiefsee-Expedition 1898-9," Deutsche Tiefsee-Expedition, vol. 2, pt. 2, pp. 1-136, 1905; pp. 137-219, 1906; pp. 223-544, 1907 .

12. van Heurck, H., "Diatomees. Resultats du Voyage du S.Y. "Belgica" en 1897-9," Expedition Antarctique Belge, vol. 6, Botany, pp. 1-126, 1909 .

13. Bailey, J.W., "Notice of Microscopic Forms Found in the Soundings of the Sea of Kamtschatka," American Journal of Science, vol. 22, ser. 2, 1856.

14. Greville, R.K., "Descriptions of Diatomaceae Observed in California Guano," Quarterly Journal Mic roscopical Science, vol. 7 , pp. $156-66,1859$.

15. Pritchard, A., A History of the Infusoria, London, 1861.

16. Castracane, A.F., Report on the Scientific Results of the Voyage of H.M.S. "Challenger" During the Years 1873-6, Botany, vol. 2, 1886.

17. Ehrenberg, C.G., Resultate Untersuchungen der ihm Sud Polreise des Capt. Rofs in den Jahren 1841-3, Bericht Berlin Akademie, pp. 182-207, 1844.

18. Ehrenberg, C.G., Neve Untersuchungen uber das Kleinste eben als Geologisches Moment, Bericht Berlin Akademie, pp. 53-88, 1845 . 
19: Cleve, P.T., "On Diatoms from the Arctic Sea," Bihang Svenska Vetenskopsakemien Akademie Handlingar, vol. 1 , No. 13, 1873.

20. Brightwell, T., “On Filamentous, Long-Horned Diatomaceae with a Description of Two New Species," Quarterly Journal Microscopical Science, vol. 4, pp. 105-9, 1856.

21. Peragallo, M., Diatomees C'Eau Douce et Diatomees d'Eau Salee, Deuxieme Expedition Antarctique Francaise $\overline{1908-10,1921 .}$

22. Ehrenberg, C.G., Uber Noch Zahlreich Jetzt Lebende Thierarten der Kreidebildung und den Organismus der Polythalamien, Berlin, 1840 and in Abhandlingar Akademie, Wissenschaften, Berlin, 1839, 1841.

23. Schmidt, A., Atlas der Diatomaceen-Kunde, 1874-1913.

24. Ehrenberg, C.G., Uber die Bildung der Kreidefelsen und des Kreide-mergels durch Unsichtbare Organismen, Abhandlingar Akademie Wis senschaften, Berlin, 1838, pp. 59-147, 1839.

25. Grunow, A., Diatomeen von Franz Josephs Land, Denkschriften der Akademie der Wissenschaften, MathematischeNaturwissenschaftliche, pp. 53-112, 1884.

26. van Heurck, H., Synopsis des Diatomees de Belgique, atlas, 1, $2(1880-1)$, text (1885). 
27. Kutzing, F.T., Die Kieselschaligen Bacillarien oder Diatomeen, 1844, Nondhausen, 1865.

28. Peragallo, H., "Monographie due genre Rhizosolenia et des quelques genres voisins," Le Diatomiste, vol. 1 , pp. 79-82, 99-117, 1892 .

29. Heiden, H., and R.W. Kolbe, "Die Marinen Diatomeen der Deutschen Sudpolar-Expedition, 1901-3," Deutsche Sudpolar Expedition, vol. 8, No. 5, pp. 450-714, 1928.

30. Smith, Wm., A Synopsis of the British Diatomaceae, vol. 1,1853 ; vol. 2,1856 .

31. Cupp, E.E., "Marine Plankton Diatoms of the West Coast of North America," Bulletin, Scripps Institution of Oceanography, University of California, vol. 5, No. 1, p. 26, 1943.

32. Cleve, P.T., Diatoms Collected during the Expedition of the "Vega", Ur Vega-Expeditionens Vetenskapliga Iakttagelser, vol. 3,1883 .

33. Cleve, P.T., and A. Grunow, "Beitrage zur Kenntniss der Arctischen Diatomeen," Svenska Vetenskopsakademien Akademie Handlingar, vol. 17, No. 2, 1880.

34. Brightwell, T., "Remarks on the Genus 'Rhizosolenia of Ehrenberg," Quarterly Journal Microscopical Science, vol. 4, pp. 93-5, 1858 . 
35. Hustedt, F., Die Kieselalgen Deutschlands, Osterreichs und der Schweiz, Rabenhorst's Kryptogammen-flora, Parts 1 and 2, 1927-33.

36. Cleve, P.T., "The Plankton of the North Sea, the English Channel, and the Skagerak in 1898," Svenska Vetenskopsakademien Akademie Handlingar, vol. 32, No. 8, 1900.

37. Gran, H.H., Diatomeen in Nordisches Plankton (Brandt, K. und C. Apstein), Lief. 3, 19, pp. 1-146, 1905.

38. O'Meara, E., "Report on the Irish Diatomaceae," Royal Irish Acadamy Procedure (ser. 2), vol. 2, Science, pp. 235-425, 1875-77.

39. Comber, T., "On the Occurrence of Endocysts in the Genus Thalassiosira," Transactions Royal Microscopical Society, pp. 489-91, 1896.

40. Jorgensen, E., "Protisplankton. The Protisplankton and the Diatoms in Bottom Samples. Hydrographical and Biological Investigations in Norwegian Fjords," Bergens Museum Skrifter, vol. 7, pp. 49-148, 1905.

41. Cleve, P.T., "Plankton Undersokningar, Cilioflagellates og Diatomaceer," Bihang Svenska, Vetenskopsakademien Akademie Handlingar, vol. 20, No. 2, 1894.

42. Woodcock, A.H., "A Theory of Surface Water Motion Deduced from the Wind-Induced Motion of the 'Physalia,' "' Journal of Marine Research, vol. 5, No. 3, pp. 196-205, 1944. 
43. Langmuir, I., "Surface Motion of Water Induced by Wind," Science, vol. 87, No. 2250, pp. 119-123, 1938.

44. Use of Oil to Calm the Sea, Reprint of Hydrographic Office Information, No. 3, 1909 .

45. Reverberation Studies at 24 Kilocycles, Reverberation Group of the University of California Division of War Research, Report No. U7, 1942.

46. Volume Reverberation: Scattering and Frequency Attenuation vs. Frequency, Reverberation Group of the University of California Division of War Research, Report No. U50, 1943.

47. Forward Scattering from the Deep Scattering Layer, Sona $r$ Data Division of the University of California Division of War Research, Report No. M398, 1946.

48. Stratification of Sound Scatterers in the Ocean, Sonar Data Division of the University of California Division of War Research, Report No. M397, 1946.

49. Studies of the Deep Scattering Layer, Sonar Data Division of the University of California Division of War Research, Report No. M445, 1946.

50. Bogorov, B.G., "Peculiarities of Diurnal Vertical Migrations of Zooplankton in Polar Seas," Journal of Marine Research, vol. 6, No. 1, pp. 25-32, 1946. 
